\title{
Comparative Approaches to Siting Low-Level Radioactive Waste Disposal Facilities
}

William F. Newberry

Published July 1994

\author{
Idaho National Engineering Laboratory \\ EG\&G Idaho, Inc. \\ Idaho Falls, Idaho 83415
}

Prepared for the

U.S. Department of Energy

Assistant Secretary for Environmental Management

Under DOE Idaho Operations Office

Contract DE-AC07-76ID01570 


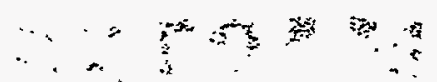




\begin{abstract}
This report describes activities in nine States to select site locations for new disposal facilities for low-level radioactive waste. These nine States have completed processes leading to identification of specific site locations for onsite investigations. For each State, the status, legal and regulatory framework, site criteria, and site selection process are described. In most cases, States and compact regions decided to assign responsibility for site selection to agencies of government and to use top-down mapping methods for site selection. The report discusses quantitative and qualitative techniques used in applying top-down screenings, various approaches for delineating units of land for comparison, issues involved in excluding land from further consideration, and different positions taken by the siting organizations in considering public acceptance, land use, and land availability as factors in site selection.
\end{abstract}

\title{
DISCLAIMER
}

\footnotetext{
This report was prepared as an account of work sponsored by an agency of the United States Government. Neither the United States Government nor any agency thereof, nor any of their employees, makes any warranty, express or implied, or assumes any legal liability or responsibility for the accuracy, completeness, or usefulness of any information, apparatus, product, or process disclosed, or represents that its use would not infringe privately owned rights. Reference herein to any specific commercial product, process, or service by trade name, trademark, manufacturer, or otherwise does not necessarily constitute or imply its endorsement, recommendation, or favoring by the United States Government or any agency thereof. The views and opinions of authors expressed herein do not necessarily state or reflect those of the United States Government or any agency thereof.
} 


\section{DISCLAIMER}

Portions of this document may be illegible in electronic image products. Images are produced from the best available original document. 


\section{FOREWORD}

This is the first in a series of planned reports describing and comparing the approaches taken by States and compact regions to develop new low-level radioactive waste disposal facilities. Under Federal laws enacted in 1980 and 1985, States are responsible for disposal of low-level radioactive waste generated within their borders and are encouraged to form compact regions to provide such disposal.

This report describes the processes used in nine States to select candidate sites to undergo detailed field investigations. These States, where siting activities progressed to this stage, are:

- California-host State for the Southwestern compact region

- Connecticut-co-host State for the Northeast compact region

- Illinois-host State for the Central-Midwest compact region

- Maine-unaffiliated State

- Michigan-former host State for the Midwest compact region

- Nebraska-host State for the Central compact region

- New York-unaffiliated State

- North Carolina-host State for the Southeast compact region

- Texas-unaffiliated State.

In Connecticut, Illinois, and New York, where one siting process has been discontinued in favor of another, the report features the process that has been substantially executed, in order to benefit from the lessons learned. Similarly, the siting processes in Maine and Michigan are described, even though site selection activities in those States have been discontinued.

The purpose of this report is to provide a basis for evaluating and comparing the differing legal and regulatory frameworks, site requirements, and general strategies for selecting site locations for the proposed disposal facilities. A comparison of the various approaches to site selection is provided at the end of the report. 


\section{CONTENTS}

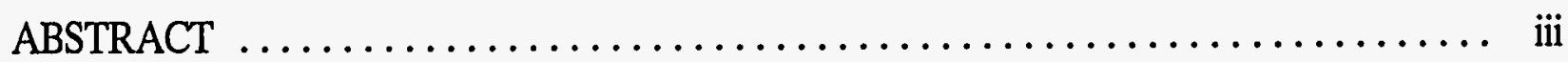

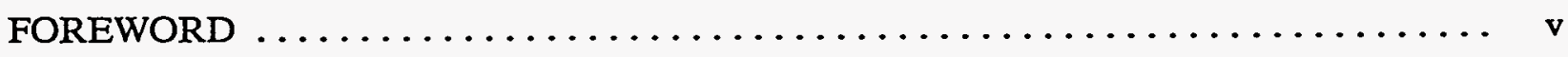

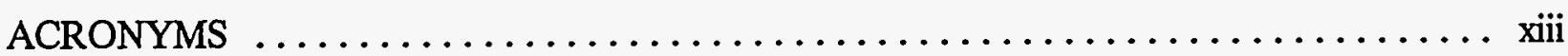

1. OVERVIEW OF CANDIDATE SITE SELECTION $\ldots \ldots \ldots \ldots \ldots \ldots \ldots \ldots$

1.1 Objectives of Candidate Site Selection $\ldots \ldots \ldots \ldots \ldots \ldots \ldots \ldots \ldots \ldots, 1$

1.2 Siting Criteria $\quad \ldots \ldots \ldots \ldots \ldots \ldots \ldots \ldots \ldots \ldots \ldots \ldots \ldots \ldots \ldots \ldots \ldots \ldots \ldots \ldots \ldots$

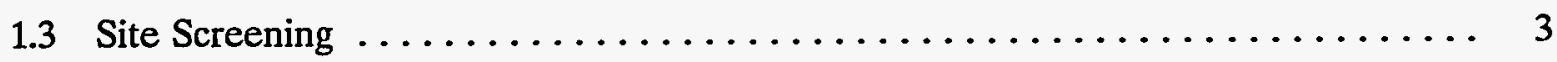

1.4 Volunteer Solicitation $\ldots \ldots \ldots \ldots \ldots \ldots \ldots \ldots \ldots \ldots \ldots \ldots \ldots \ldots \ldots \ldots \ldots \ldots$

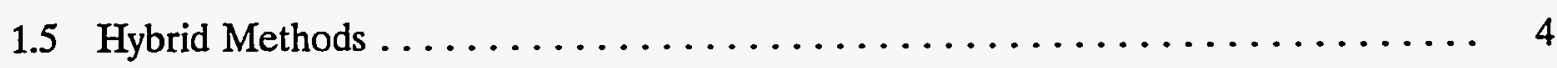

2. CALIFORNIA-SOUTHWESTERN COMPACT REGION ............ 5

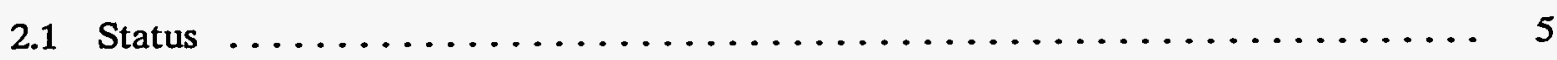

2.2 Legal and Regulatory Framework $\ldots \ldots \ldots \ldots \ldots \ldots \ldots \ldots \ldots \ldots$

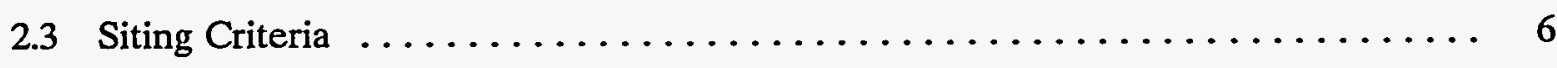

2.4 Site Selection Process $\ldots \ldots \ldots \ldots \ldots \ldots \ldots \ldots \ldots \ldots \ldots \ldots \ldots \ldots \ldots \ldots \ldots$

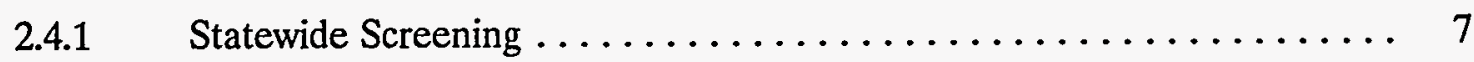

2.4.2 Identification of Topographically Closed Basins $\ldots \ldots \ldots \ldots \ldots \ldots 8$

2.4.3 Exclusion of Basins $\ldots \ldots \ldots \ldots \ldots \ldots \ldots \ldots \ldots \ldots \ldots \ldots \ldots$

2.4.4 Public Participation in Developing Area-Level Criteria $\ldots \ldots \ldots \ldots 13$

2.4.5 Area-Level Screening . . . . . . . . . . . . . . . . . . . 13

2.4.6 Preference Screening Using CAC Criteria $\ldots \ldots \ldots \ldots \ldots \ldots \ldots . \ldots \ldots$

2.4.7 Comparison of Candidate Siting Areas . . . . . . . . . . . . . 14

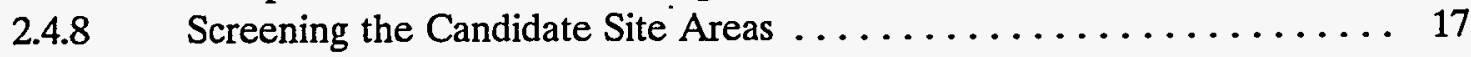

2.4.9 Identification of Candidate Sites $\ldots \ldots \ldots \ldots \ldots \ldots \ldots \ldots \ldots \ldots$

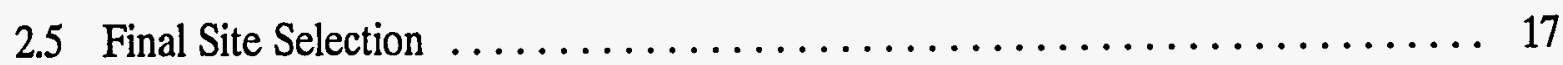

3. CONNECTICUT-NORTHEAST COMPACT REGION $\ldots \ldots \ldots \ldots \ldots \ldots \ldots . . \ldots$

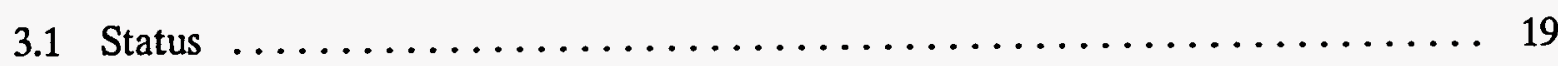

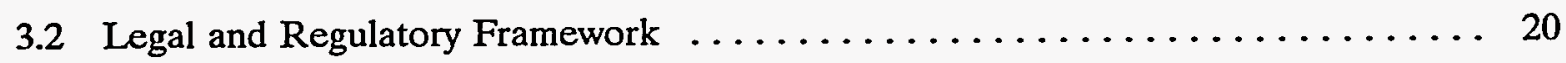

vii 


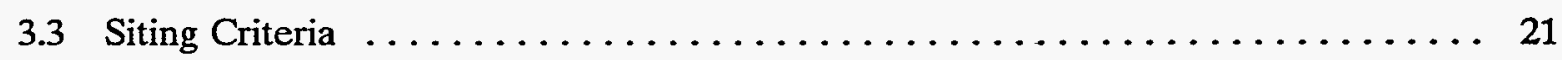

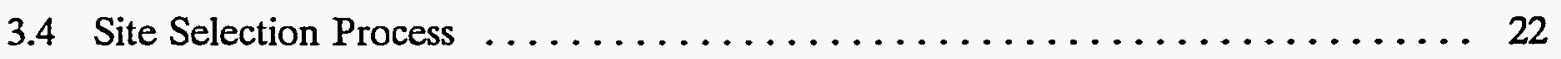

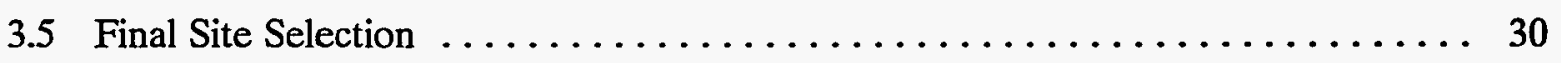

4. ILLINOIS-CENTRAL-MIDWEST COMPACT REGION $\ldots \ldots \ldots \ldots \ldots \ldots \ldots$

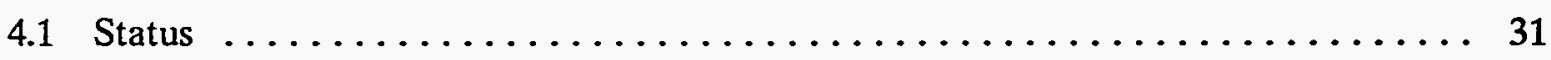

4.2 Legal and Regulatory Framework $\ldots \ldots \ldots \ldots \ldots \ldots \ldots \ldots \ldots \ldots \ldots \ldots$

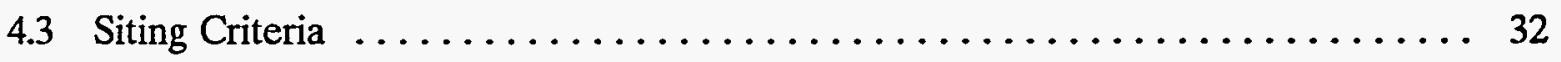

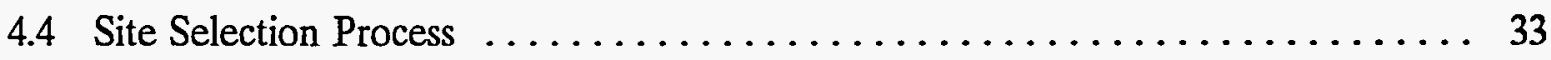

4.4.1 Identification of Counties to Undergo Evaluation $\ldots \ldots \ldots \ldots \ldots \ldots$

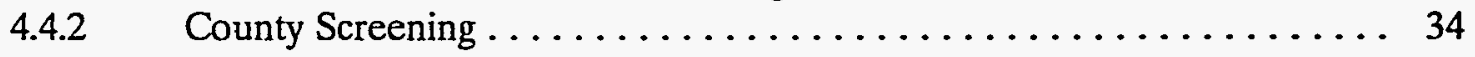

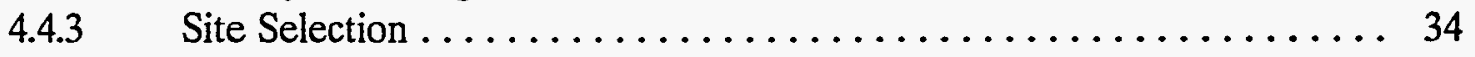

4.4.4 Concerns of the Illinois Siting Commission ............... 36

4.5 Final Site Selection $\ldots \ldots \ldots \ldots \ldots \ldots \ldots \ldots \ldots \ldots \ldots \ldots \ldots \ldots \ldots \ldots \ldots \ldots \ldots$

5. MAINE-UNAFFILIATED STATE $\ldots \ldots \ldots \ldots \ldots \ldots \ldots \ldots \ldots \ldots \ldots \ldots \ldots$

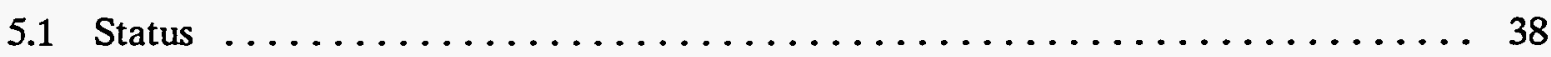

5.2 Legal and Regulatory Framework $\ldots \ldots \ldots \ldots \ldots \ldots \ldots \ldots \ldots \ldots \ldots \ldots$

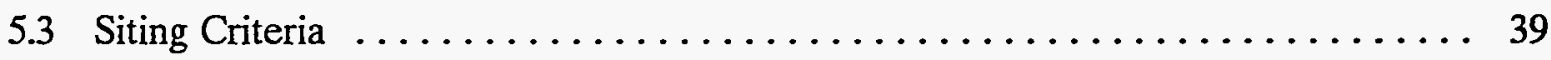

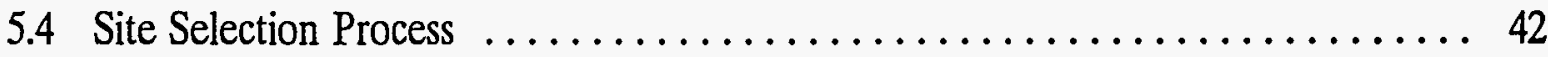

5.4.1 The Screening Process $\ldots \ldots \ldots \ldots \ldots \ldots \ldots \ldots \ldots \ldots \ldots \ldots \ldots \ldots \ldots$

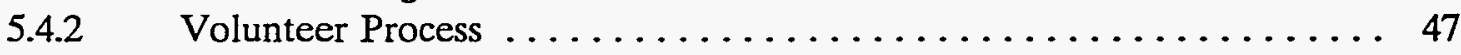

$5.4 .3 \quad$ Demographics of the Sites $\ldots \ldots \ldots \ldots \ldots \ldots \ldots \ldots \ldots \ldots$

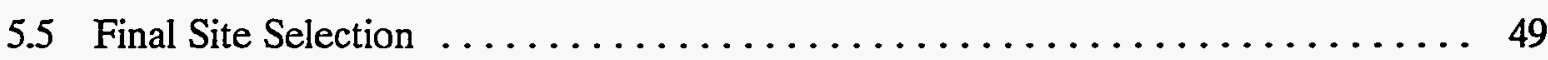

6. MICHIGAN-MIDWEST COMPACT REGION $\ldots \ldots \ldots \ldots \ldots \ldots \ldots \ldots .50$

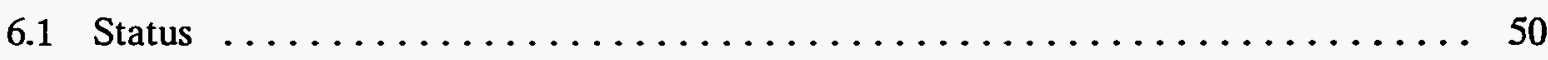

6.2 Legal and Regulatory Framework $\ldots \ldots \ldots \ldots \ldots \ldots \ldots \ldots \ldots \ldots$

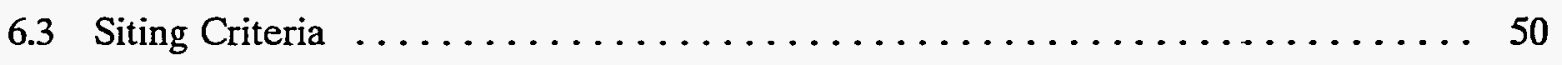




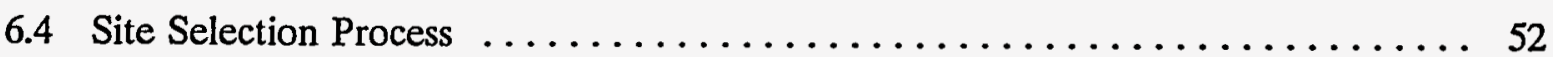

6.4.1 Selection of Siting Strategy $\ldots \ldots \ldots \ldots \ldots \ldots \ldots \ldots \ldots \ldots, 52$

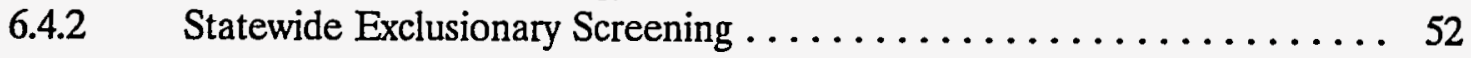

$6.4 .3 \quad$ Area-Level Evaluation .......................... 54

6.4.4 Reexamination of the Deferred Areas ................... 54

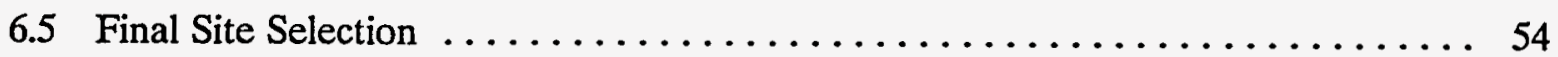

7. NEBRASKA-CENTRAL COMPACT REGION $\ldots \ldots \ldots \ldots \ldots \ldots \ldots \ldots$

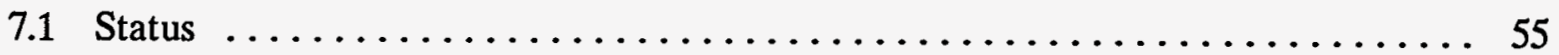

7.2 Legal and Regulatory Framework $\ldots \ldots \ldots \ldots \ldots \ldots \ldots \ldots \ldots \ldots$

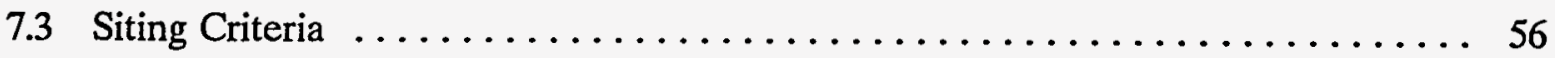

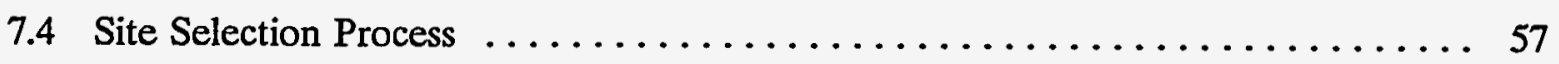

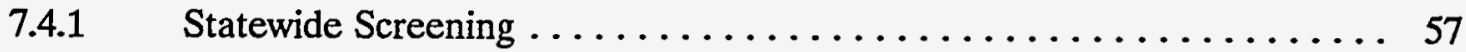

7.4.2 Regional Screening/Community Consent $\ldots \ldots \ldots \ldots \ldots \ldots \ldots . \ldots$

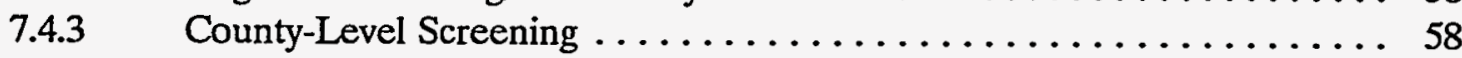

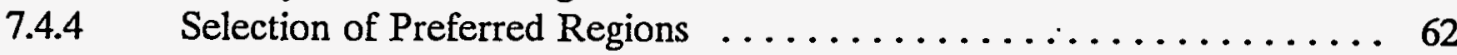

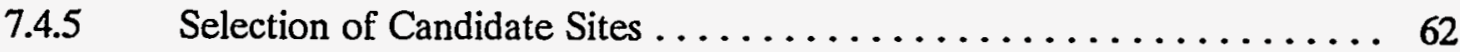

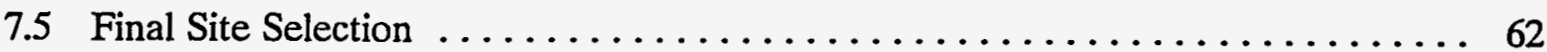

8. NEW YORK-UNAFFILIATED STATE $\ldots \ldots \ldots \ldots \ldots \ldots \ldots \ldots \ldots \ldots \ldots$

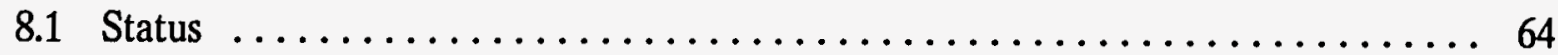

8.2 Legal and Regulatory Framework $\ldots \ldots \ldots \ldots \ldots \ldots \ldots \ldots \ldots \ldots \ldots$

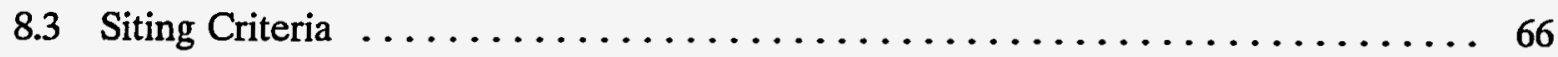

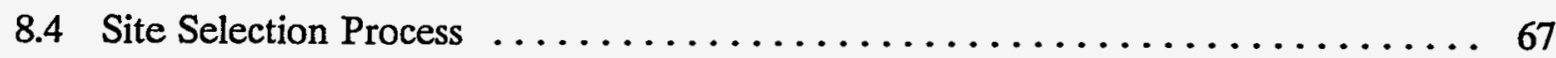

8.4.1 Additional Exclusionary Criteria $\ldots \ldots \ldots \ldots \ldots \ldots \ldots \ldots \ldots, 68$

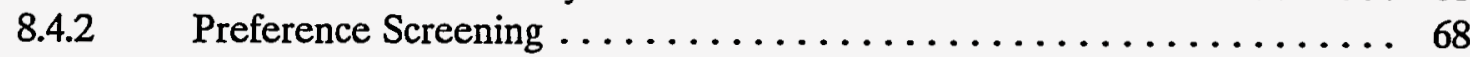

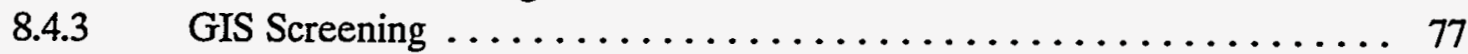

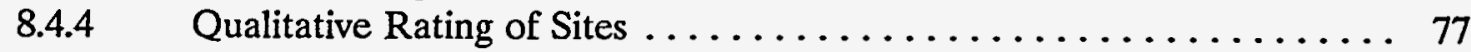

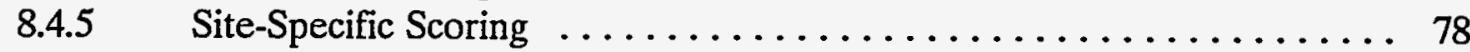

8.4.6 Designation of Five Sites for Precharacterization ............ 78

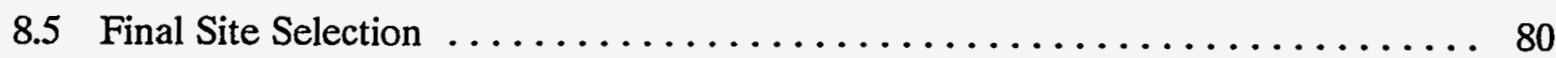

9. NORTH CAROLINA-SOUTHEAST COMPACT REGION $\ldots \ldots \ldots \ldots \ldots \ldots . \ldots 4$ 


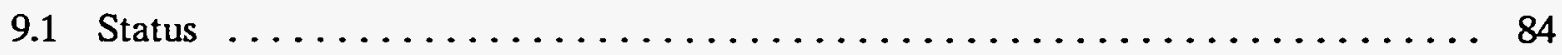

9.2 Legal and Regulatory Framework $\ldots \ldots \ldots \ldots \ldots \ldots \ldots \ldots \ldots$

9.3 Siting Criteria $\ldots \ldots \ldots \ldots \ldots \ldots \ldots \ldots \ldots \ldots \ldots \ldots \ldots \ldots$

9.4 Site Selection Process $\ldots \ldots \ldots \ldots \ldots \ldots \ldots \ldots \ldots \ldots \ldots \ldots \ldots$

9.4.1 Application of Exclusionary Criteria . . . . . . . . . . . . . 87

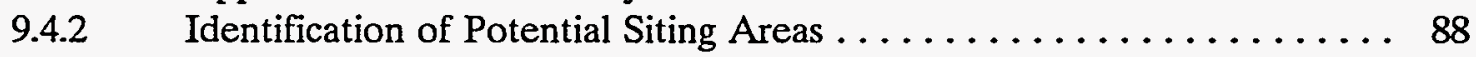

9.4.3 Selection of Sites for Characterization $\ldots \ldots \ldots \ldots \ldots \ldots \ldots \ldots 90$

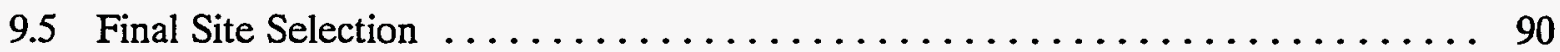

10. TEXAS-UNAFFILIATED STATE $\ldots \ldots \ldots \ldots \ldots \ldots \ldots \ldots \ldots \ldots \ldots \ldots \ldots \ldots \ldots$

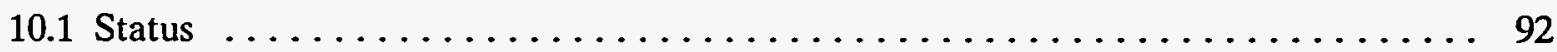

10.2 Legal and Regulatory Framework $\ldots \ldots \ldots \ldots \ldots \ldots \ldots \ldots \ldots \ldots \ldots \ldots \ldots \ldots$

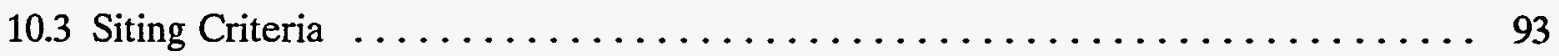

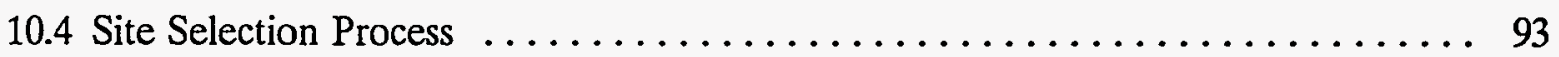

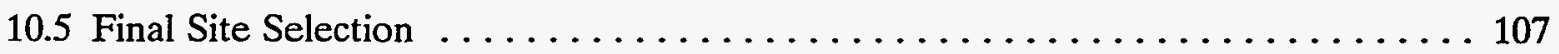

11. EVALUATION OF APPROACHES TO SITE SELECTION $\ldots \ldots \ldots \ldots \ldots \ldots$

11.1 Legal and Regulatory Framework $\ldots \ldots \ldots \ldots \ldots \ldots \ldots \ldots \ldots \ldots \ldots \ldots \ldots \ldots \ldots$

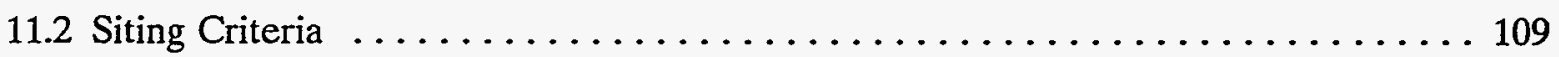

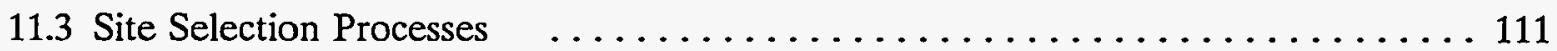

11.3.1 Governmental Approaches to Site Selection $\ldots \ldots \ldots \ldots \ldots \ldots \ldots 111$

11.3.2 Prevalence of Top-Down Screening Processes ............. 112

11.3.3 Quantitative and Qualitative Approaches $\ldots \ldots \ldots \ldots \ldots \ldots \ldots 113$

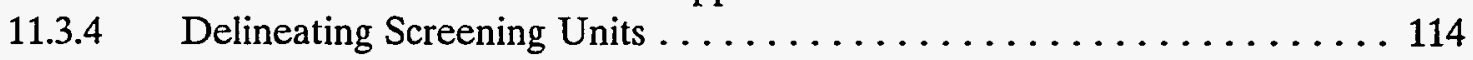

11.3.5 Excluding Land Area from Further Consideration $\ldots \ldots \ldots \ldots \ldots 115$

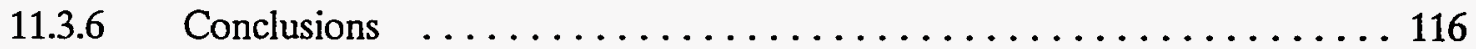

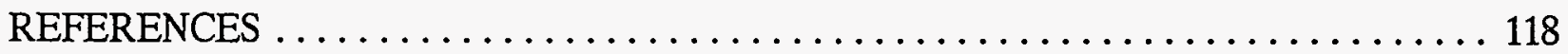

\section{FIGURES}

1. Mean annual rainfall greater than 10 in $\ldots \ldots \ldots \ldots \ldots \ldots \ldots \ldots \ldots$ 
2. Areas remaining after application of DHS criteria-first-level screening $\ldots \ldots \ldots \ldots$

3. Areas remaining after application of technical suitability criteria-second-level screening $\ldots \ldots \ldots \ldots \ldots \ldots \ldots \ldots \ldots \ldots \ldots \ldots \ldots \ldots \ldots \ldots \ldots \ldots \ldots$

4. Topographically closed basins in southeastern California $\ldots \ldots \ldots \ldots \ldots \ldots \ldots \ldots$

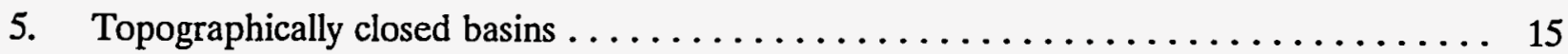

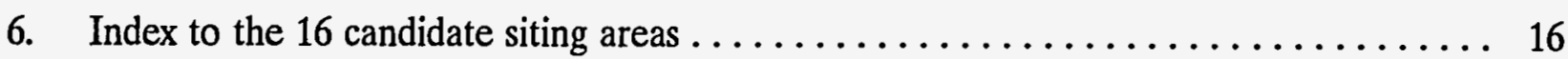

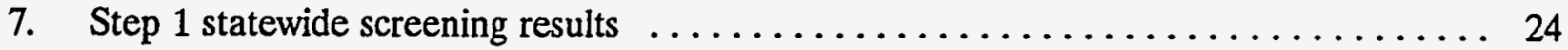

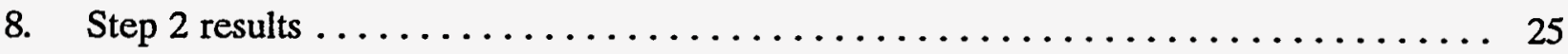

9. Potential sites remaining after application of slope criterion $\ldots \ldots \ldots \ldots \ldots \ldots$

10. Composite favorability Clark County $\ldots \ldots \ldots \ldots \ldots \ldots \ldots \ldots \ldots \ldots \ldots \ldots \ldots \ldots \ldots \ldots$

11. Composite statewide exclusion map $\ldots \ldots \ldots \ldots \ldots \ldots \ldots \ldots \ldots \ldots \ldots \ldots$

12. Composite statewide screening map $\ldots \ldots \ldots \ldots \ldots \ldots \ldots \ldots \ldots \ldots \ldots$

13. Towns within candidate regions $\ldots \ldots \ldots \ldots \ldots \ldots \ldots \ldots \ldots \ldots \ldots \ldots$

14. Candidate site (pending Authority approval) and volunteered sites . . . . . . . 48

15. Results of State and regional screening $\ldots \ldots \ldots \ldots \ldots \ldots \ldots \ldots$

16. Map of Boyd County, Nebraska $\ldots \ldots \ldots \ldots \ldots \ldots \ldots \ldots \ldots \ldots \ldots \ldots \ldots \ldots \ldots \ldots \ldots$

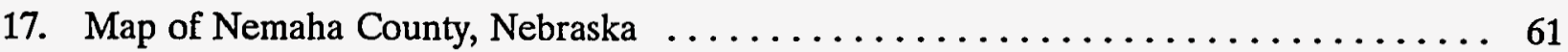

18. Step 1 analysis: Statewide exclusionary screening . . . . . . . . . . . . . 69

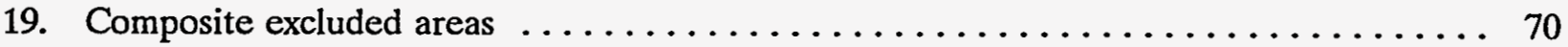

20. Composite favorability map $\ldots \ldots \ldots \ldots \ldots \ldots \ldots \ldots \ldots \ldots \ldots \ldots \ldots$

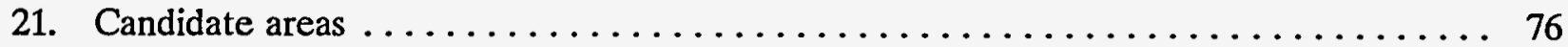

22. Location of five sites in Cortland and Allegany Counties $\ldots \ldots \ldots \ldots \ldots \ldots \ldots$

23. Recommended potential site $13-18 \ldots \ldots \ldots \ldots \ldots \ldots \ldots \ldots \ldots \ldots \ldots$

24. Potentially suitable areas $\ldots \ldots \ldots \ldots \ldots \ldots \ldots \ldots \ldots \ldots \ldots \ldots \ldots$ 
25. Groundwater exclusionary areas $\ldots \ldots \ldots \ldots \ldots \ldots \ldots \ldots \ldots \ldots \ldots \ldots \ldots \ldots$

26. Composite potential siting areas $\ldots \ldots \ldots \ldots \ldots \ldots \ldots \ldots \ldots \ldots \ldots \ldots$

27. Abilene-Haskell Plains composite regional screening $\ldots \ldots \ldots \ldots \ldots \ldots \ldots \ldots$

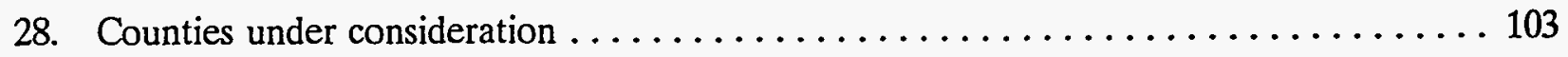

\section{TABLES}

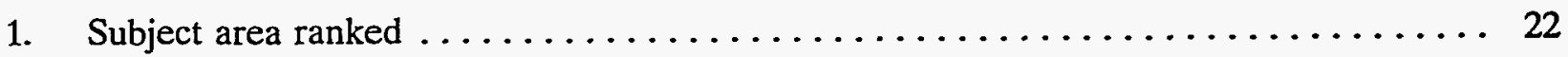

2. Data matrix for panel workshop two $\ldots \ldots \ldots \ldots \ldots \ldots \ldots \ldots \ldots \ldots \ldots$

3. Screening criteria and factors $\ldots \ldots \ldots \ldots \ldots \ldots \ldots \ldots \ldots \ldots \ldots \ldots \ldots$

4. General criteria statements $\ldots \ldots \ldots \ldots \ldots \ldots \ldots \ldots \ldots \ldots \ldots \ldots \ldots \ldots \ldots$

5. Summary of evaluation of potential candidate areas $\ldots \ldots \ldots \ldots \ldots \ldots \ldots \ldots$

6. Results of limited site inspections of sites set aside $\ldots \ldots \ldots \ldots \ldots \ldots \ldots \ldots \ldots$

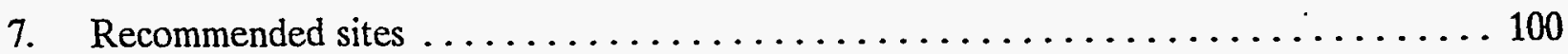

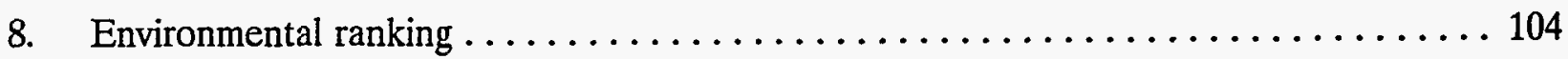

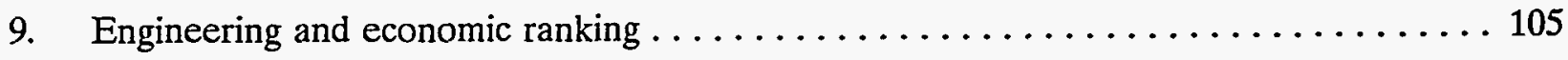

10. State organizational approaches to site selection $\ldots \ldots \ldots \ldots \ldots \ldots \ldots \ldots \ldots \ldots$ 


\section{ACRONYMS}

\begin{tabular}{|c|c|}
\hline ALARA & as low as reasonably achievable \\
\hline ANSI & American National Standards Institute \\
\hline ASME & American Society of Mechanical Engineers \\
\hline BLM & Bureau of Land Management \\
\hline $\mathrm{CAC}$ & Citizens Advisory Committee \\
\hline CAG & Citizens Advisory Group \\
\hline CAIR & Candidate Area Identification Report \\
\hline CFR & Code of Federal Regulations \\
\hline CNSI & Chem-Nuclear Systems, Inc. \\
\hline CSA & candidate siting areas (California) \\
\hline DEQ & Department of Environmental Quality (Nebraska) \\
\hline DEP & Department of Environmental Protection (Maine) \\
\hline DHS & Department of Health Services (California) \\
\hline GAO & General Accounting Office \\
\hline GIS & geographic information system \\
\hline IDNS & Illinois Department of Nuclear Safety \\
\hline NCAC & North Carolina Administrative Code \\
\hline NQA & Nuclear Quality Assurance \\
\hline NRC & Nuclear Regulatory Commission \\
\hline NYSERDA & New York State Energy Research and Development Authority \\
\hline PSA & potential siting area \\
\hline USGS & United States Geological Survey \\
\hline
\end{tabular}




\section{Comparative Approaches to Siting Low-Level Radioactive Waste Disposal Facilities}

\section{OVERVIEW OF CANDIDATE SITE SELECTION}

\subsection{Objectives of Candidate Site Selection}

Federal laws make States responsible for the disposal of low-level radioactive waste generated within their borders, and encourage States to form interstate compact regions for disposal of the waste. An early step in the establishment of new disposal facilities is to define a process for selecting a location for such a facility.

The principal objective of siting processes is to identify locations which, based on preexisting or surficial information, appear likely to meet site requirements for such a facility. Verification of the quality of a candidate site can only be done through extensive onsite "characterization." Because public acceptance is often important to the success of the project, another common objective is to identify candidate sites within supportive communities. For practical considerations, organizations responsible for siting may also strive to select sites on land that is available for purchase or that can be easily acquired.

\subsection{Siting Criteria}

"Siting criteria" is a term used to encompass a range of descriptive statements about characteristics that are necessary or desirable in a site location. Where applicable data are available to evaluate land area against siting criteria, the criteria may be used to eliminate land from consideration as part of a phased, top-down mapping process. The same criteria can also be used to evaluate or compare specific sites that have become candidates through some other process.

Siting criteria are a composite of requirements that encompass different values and objectives. Technical criteria are used to evaluate the ability of a proposed site to successfully isolate the waste from the environment. Land use criteria reflect public attitudes toward protection of resources such as parks and recreation areas. Public acceptance and land availability criteria aim to minimize disruption caused by the development of a low-level radioactive waste disposal site.

Technical criteria are often derived from the "disposal site suitability requirements" in 10 Code of Federal Regulations (CFR) Part 61.50. They are:

- The site must be capable of being characterized, modeled, and monitored

- The site must be located so that future population growth and development will not affect the ability of the site to meet performance objectives 
- The site cannot be located where future exploitation of natural resources might affect the ability of the site to meet performance objectives

- The site must be generally well-drained and free of areas of flooding or frequent ponding (waste disposal shall not take place in a 100-year flood plain, coastal highhazard area, or wetland)

- Any runoff from upstream drainage must be minimized so as not to cause surface erosion or risk inundating waste disposal units

- The site must provide sufficient depth to the water table so that water intrusion does not occur

- The hydrogeologic unit used for disposal cannot discharge groundwater to the surface within the disposal site

- The site must not be located where tectonic processes or surface geologic processes are likely to affect the ability of the site to meet performance objectives

- The site must not be located where nearby facilities could adversely impact the ability of the site to meet performance objectives.

The performance objectives referred to in the site suitability requirements are in 10 CFR 61.40. They are:

- Protection of the general population from releases of radioactivity

- Protection of individuals who inadvertently intrude into the site or occupy the site after the active institutional control period

- Protection of individuals during operation and maintaining exposure to workers at a level as low as reasonably achievable (ALARA)

- Stability of the disposal site after closure, so that only surveillance, monitoring, or minor custodial care is required.

All of the States currently pursuing the development of new disposal facilities, except Connecticut, are or plan to become U.S. Nuclear Regulatory Commission (NRC) "agreement States." In agreement States, all of the Federal disposal site suitability requirements and performance objectives are adopted as State regulations. Derivations of these regulatory requirements and additional criteria may appear in policy statements, technical reports, or other documentation produced by agencies and organizations involved in site selection. A number of States have decided to codify additional siting criteria in the form of State regulations, and a few have adopted siting criteria in the form of legislation. 
Although basic requirements for land disposal facilities for low-level radioactive waste are generally well-documented in such reports as the Site Characterization Handbook for Low-Level Radioactive Waste Disposal Facilities (EG\&G Idaho 1992), technical contractors and public advisory groups have often been used by States to refine criteria for application and to prioritize criteria through weighting techniques or other methods.

\subsection{Site Screening}

"Site screening" is a broad term that has been used to depict a variety of methods for selecting specific site locations from a larger study area. Most often, the term is used to refer to a site selection process involving top-down methods, whereby areas are eliminated from consideration in successive phases of mapping until the final candidate site or sites are identified.

In recent years, top-down screening methods have generally employed standard geographical information systems (GISs) that use digitized data representing siting criteria to generate composite maps showing areas more or less favorable for siting. Such techniques are limited by the availability of credible data that faithfully represent the site requirements at the appropriate scale. Generally, only those criteria for which good data exist across the entire study area are used in such screenings.

In recent years, reservations have been expressed about the use of these methods for siting controversial facilities, largely because the map scales for which much of the data are available tend to eliminate large amounts of land in broad-brush fashion which, at a smaller scale, might be shown to meet site requirements. It has also been observed that most of the siting criteria for which screening data are available are not criteria that are related to long-term safety and performance of a disposal site. For example, excluding State-protected areas from consideration for the disposal facility may be a worthwhile objective, but such a criterion is unrelated to the ability of the land to isolate radioactive waste for long periods of time.

Two significant issues have been raised in using top-down screening methods to identify candidate sites for low-level radioactive waste disposal facilities. The first issue is whether or at what stage mechanical mapping processes, using cataloged data, should give way to actual field reconnaissance by technical experts. States that use a GIS or other mapping techniques to screen a study area from top to bottom, may miss negative characteristics for which cataloged data are not available. This can make the process appear stilted and the siting organization ill-informed about observable characteristics of the land. On the other hand, States that turn to field reconnaissance and professional judgment in the latter stages of site selection often lack documentation showing that decisions were based on "objective" technical considerations.

The second issue involves the stage at which the search turns from candidate areas to specific candidate sites. Technically speaking, the amount of land needed for a disposal facility could be less than 100 acres. Ideally, to select a site in a State, all 100-acre parcels in the State should be compared against each other. This, however, is not practical. Competing candidate areas often contain many square miles of land, with some portions better suited for low-level radioactive waste disposal than others. These candidate areas are compared with each other for inclusion or exclusion in subsequent steps based on large-scale, generalized data that may or may 
not be representative of all the 100 -acre parcels within the area. A process that eliminates competing candidate areas as whole units can also eliminate a lot of land that might be suitable for a disposal facility.

For controversial facilities, there appear to be two bases for expecting that a top-down screening process will succeed. They are: (a) that communities chosen through such processes will accept the designation because the facility is needed and the process was fair, or (b) that State leaders will be willing to see the process through, in spite of local opposition. Recognizing that the latter course is more realistic, most States have granted the siting organization the power of eminent domain in order to acquire candidate sites from landowners unwilling to sell. However, the willingness to execute top-down processes to their conclusion in the face of local opposition has varied from State to State.

\subsection{Volunteer Solicitation}

Most State processes include tracks that involve solicitation of volunteers through incentive programs. A critical factor in such an approach is whether the volunteering entity should be an individual landowner, or a geographical unit such as a county or township. Individual landowners eager to sell their property have been fairly common, but such offers invariably have engendered

opposition from the communities in which the land is located. Communities interested in hosting the facility may or may not have sites that meet the siting criteria.

Volunteer programs are difficult to integrate with top-down screening processes, although most States conducting top-down screenings have also created volunteer tracks. The reason the two methods are not easily integrated is because top-down processes eliminate large areas based on data that generalize characteristics of the entire area from a relatively few measurements at discrete points within the area. Therefore, volunteered sites that meet all siting requirements when evaluated on a site-specific scale may well be located within areas previously found "unsuitable," or less suitable through a top-down screening process. Selection of an acceptable site within a less suitable area is counterintuitive and may appear to the public to be expedient. Because of the perception that any land eliminated during any stage of a top-down screening must be unsuitable, a few States have rejected top-down screening applications altogether in favor of case-by-case evaluation of specific volunteered sites.

\subsection{Hybrid Methods}

In two States, Nebraska and Illinois, the siting organizations combined features of top-down screenings with those of voluntary processes. This was done by considering some form of "community consent" as an actual siting criteria to be applied at a strategic stage in siting. In both cases, land area was eliminated through a first-cut geotechnical exclusionary screening. At that point, the community consent criterion was applied to eliminate entire county units whose governing boards indicated that they did not want to be screened further. These processes effectively limited the rest of the screening process to volunteer counties. 


\section{CALIFORNIA-SOUTHWESTERN COMPACT REGION}

The Southwestern compact region, formed in 1988, includes Arizona, California, North Dakota, and South Dakota. Under terms of the compact, California is the host State for the region's first disposal facility for low-level radioactive waste. In 1982, prior to entering a compact, California had enacted legislation authorizing the Department of Health Services (DHS) to site and license a disposal facility. California Senate Bill 342 (1983) directs DHS to select a company in the private sector as license-designee to site, develop, and operate the facility.

\subsection{Status}

As license designee, US Ecology, Inc., began a site selection process in 1986, resulting in identification of three candidate sites in April 1987. Characterization of the three sites began during the same year. After characterizing the sites, US Ecology selected the Ward Valley location as the preferred site in March 1988. DHS began evaluating the license application in December 1989, and issued a license in September 1993.

Development of the disposal facility has been delayed by a dispute over the need for, and extent of, adjudicatory hearings concerning the site outside the normal licensing process. Under pressure from a legislative committee, DHS agreed in April 1992 to conduct an adjudicatory hearing on the proposed site. In response to litigation over the hearings, a State appellate court voided the agreement in May 1993 finding that the agreement usurped administrative discretion. The State Supreme Court upheld the decision in August 1993. Although views differed over whether DHS still had authority to hold the hearings in the absence of the agreement, the governor took the position that holding such hearings would be inconsistent with the ruling.

The Federal government then became involved in the process. Because the site is located on land owned by the Bureau of Land Management (BLM) under the U.S. Department of the Interior, opponents and proponents of the site focussed their efforts on the Federal process for transferring land to States. Following an exchange of proposals between the governor of California and the Secretary of the Interior, the Secretary announced in March 1994 that he would condition transfer of the land to the State on a favorable review by the National Academy of Sciences of issues related to the geohydrology of the site.

\subsection{Legal and Regulatory Framework}

Among State laws directing establishment of disposal facilities for low-level radioactive waste, California's law is unique in its approach. Instead of giving a State agency or quasi-State agency direct responsibility for the development, the law outlined a process by which the private sector would be enlisted to establish the needed facility, using its own capital for funding. (In Nebraska, the only other State where the project is a private sector endeavor, the project was implemented by the Central States Compact Commission rather than the State, and is funded by waste generators through the Compact Commission.)

California's 1983 law (Senate Bill 342, Chapter 1177) does not require a specific method for selecting the site location. The law does, however, require that the governor: 
direct the appropriate State agency or agencies ... to conduct and complete a study which identifies those regions of the State within which it is likely the criteria developed pursuant to (another section of the law) could be met [Section 4(e)].

The law does not prescribe siting criteria, but does require DHS to submit a comprehensive plan for management and disposal of low-level radioactive waste to the legislature. In one element of the plan, the law requires DHS to consider the following factors:

- Present and projected uses of land, water, and natural resources

- $\quad$ Proximity to major population centers

- Presence of faults

- Geologic and other natural barriers

- The effectiveness of engineered barriers, waste treatment, and waste packaging in ensuring isolation of the waste

- Transportation

- Economic impacts of the location.

The statute gives DHS authority to adopt rules necessary to implement the law. The rules adopted by DHS incorporate by reference the basic site requirements of 10 CFR 61.50. Beyond this, however, DHS regulations do not limit the discretion of the site developer by requiring particular siting strategies and methods. The regulations require the license designee to provide a "description of the natural and demographic characteristics which will be emphasized in selection of the disposal site, including geologic, hydrologic, meteorologic, climatologic and biotic features of the disposal site and vicinity," and to provide "a plan for community involvement" (Title 17, Group 7, Article 4, Para 30477). This strategy of leaving flexibility in the method and criteria for site selection allowed the company siting the facility to work directly with local officials and the public to select candidate sites.

\subsection{Siting Criteria}

Basic siting criteria are provided in Title 17, Section 30470, of the California Administrative Code. These regulations are essentially identical to the siting requirements in 10 CFR Part 61.50 (see Section 1.2 of this report). DHS decided to include additional nonbinding guidance in its report to the legislature, dated December 1982. The report stated, "The standards and rationale behind their development are general and cite more specific discussions of the relevant issues. Flexibility must be preserved in considering how individual characteristics of the site and the waste will interact." 
Of the 14 guidelines, those that provide guidance beyond the siting regulations are:

- Areas containing critical habitats of endangered species or cultural resources should be avoided

- Economic impact analysis of a proposed site should be undertaken and compensatory mechanisms should be considered

- A site should be accessible by all-weather roads

- A site should not be located in areas where it would degrade groundwater quality

- $\quad$ Excavated soils should be evaluated for appropriateness as backfill and trench cap material

- A semi-arid climate with low frequency of extreme weather events is optimal for siting

- The facility should be located where utilities can be made available

- The facility should not be located so remotely as to impair the administration of security and fire services.

The preestablished criteria served to narrow the focus of the search to a specific geographic area. Once the target area had been identified, further siting criteria were developed by US Ecology through a series of workshops involving a Citizens Advisory Group and residents of the area. This process is summarized in the sections that follow.

\subsection{Site Selection Process}

\subsubsection{Statewide Screening}

To identify regions in which suitable sites might be located, as required by the California law, the State DHS conducted a broad screening of the State in 1982. Mapping of each criterion was done at a scale of 1:1,000,000, and a composite map was prepared using manual techniques. The screening excluded land that met the following conditions:

- Irrigated and irrigable land

- Population density of more than 1,000 persons $/ \mathrm{mi}^{2}$ in the year 2000

- National and State forests

- Mean annual rainfall greater than 10 in.

- National and State parks, monuments, wildlife refuges, and recreational areas. 
Of these criteria, the requirement for $10 \mathrm{in.} \mathrm{or} \mathrm{less} \mathrm{of} \mathrm{annual} \mathrm{rainfall} \mathrm{was,} \mathrm{by} \mathrm{far,} \mathrm{the} \mathrm{most}$ significant in excluding land from further consideration. Compare, for example, Figure 1, from DHS' Area Suitability Study, showing excluded areas with annual rainfall greater than 10 in., to Figure 2, from US Ecology's Candidate Site Selection Report, which shows the final results of first-level screening.

In December 1985, after DHS negotiated with several companies, US Ecology accepted license-designee status to site and develop the facility. The company decided to adopt the results of DHS' first-level screening, except for the exclusion of irrigable lands, which the company did not believe to be closely related to any of the siting criteria, and for which credible data were unavailable. The exception had little effect on the outcome, which was dominated by the rainfall criteria.

\subsubsection{Identification of Topographically Closed Basins}

The next significant step in excluding land from consideration resulted from a decision by US Ecology to prefer land in topographically closed basins, a siting luxury that few States enjoy. The criteria was an application of the regulatory requirement that sites be capable of being characterized, modeled, analyzed, and monitored. Based on United States Geological Survey (USGS) topographical maps, the criterion eliminated much of the land in central California in the San Joaquin Valley and land basins in the far southeastern part of the State that drained into the Colorado River (see Figure 3). Topographically closed basins in southeastern California are shown in Figure 4.

\subsubsection{Exclusion of Basins}

At this step in the process, US Ecology evaluated each of the 71 basins against the siting criteria in order to focus on basins that appeared most likely to yield suitable sites. This was done in two phases. The first, which considered technical siting criteria, reduced the number of basins under consideration to 30 . In the second phase, the consideration of institutional criteria further reduced the number to 18 .

Entire basins were eliminated from further consideration if any part of the basin contained features inconsistent with the siting criteria. The method for eliminating basins in this fashion was essentially qualitative, based on regional technical studies and professional judgment. The results are documented in the US Ecology report, California Low-Level Radioactive Waste Disposal Facility Candidate Sites Selection Report. The technical basis given in the report for elimination of one basin is typical:

Basin \#70. "Honey Lake Valley was eliminated for the following reasons:

- Depth to groundwater is less than $100 \mathrm{ft}$ in large areas of the valley floor (DWR 1963b).

- Potentially active and active faults (sic), such as the Honey Lake Fault and the Fort Sage Fault, exist in the southwestern and southern portion of the valley (CDMG 1975). 


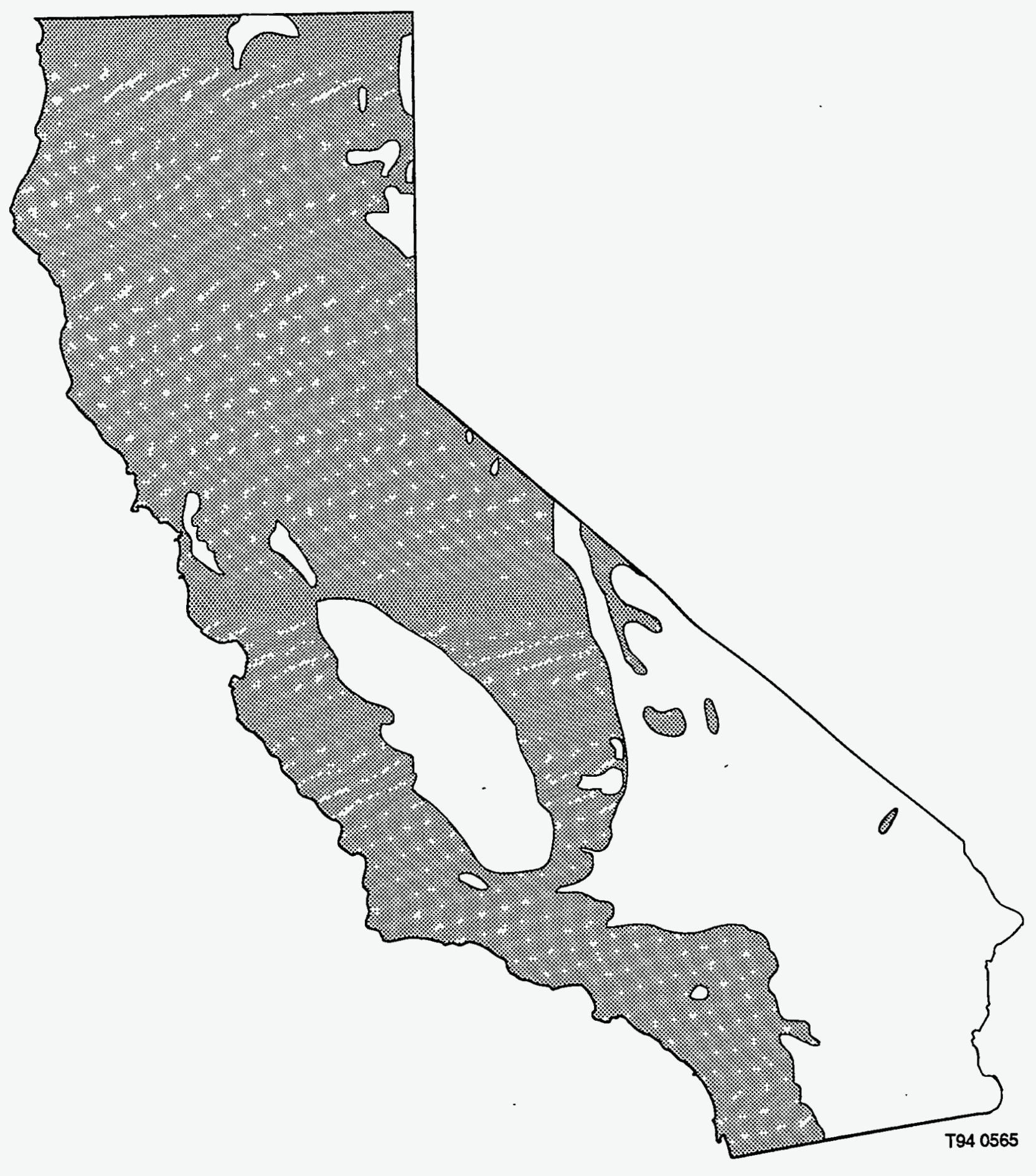

Figure 1. Mean annual rainfall greater than $10 \mathrm{in.}$ 


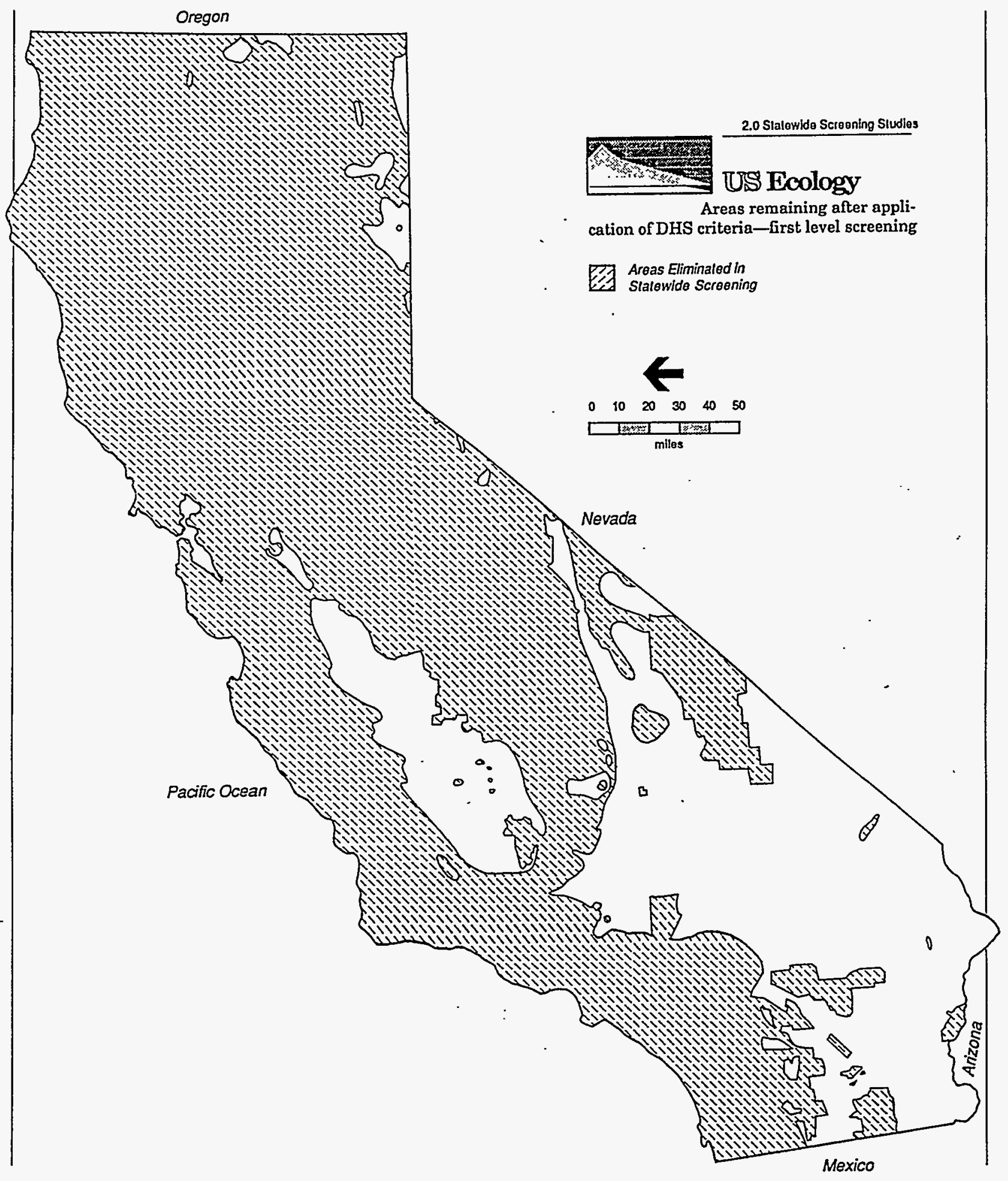

Figure 2. Areas remaining after application of DHS criteria-first level screening. 


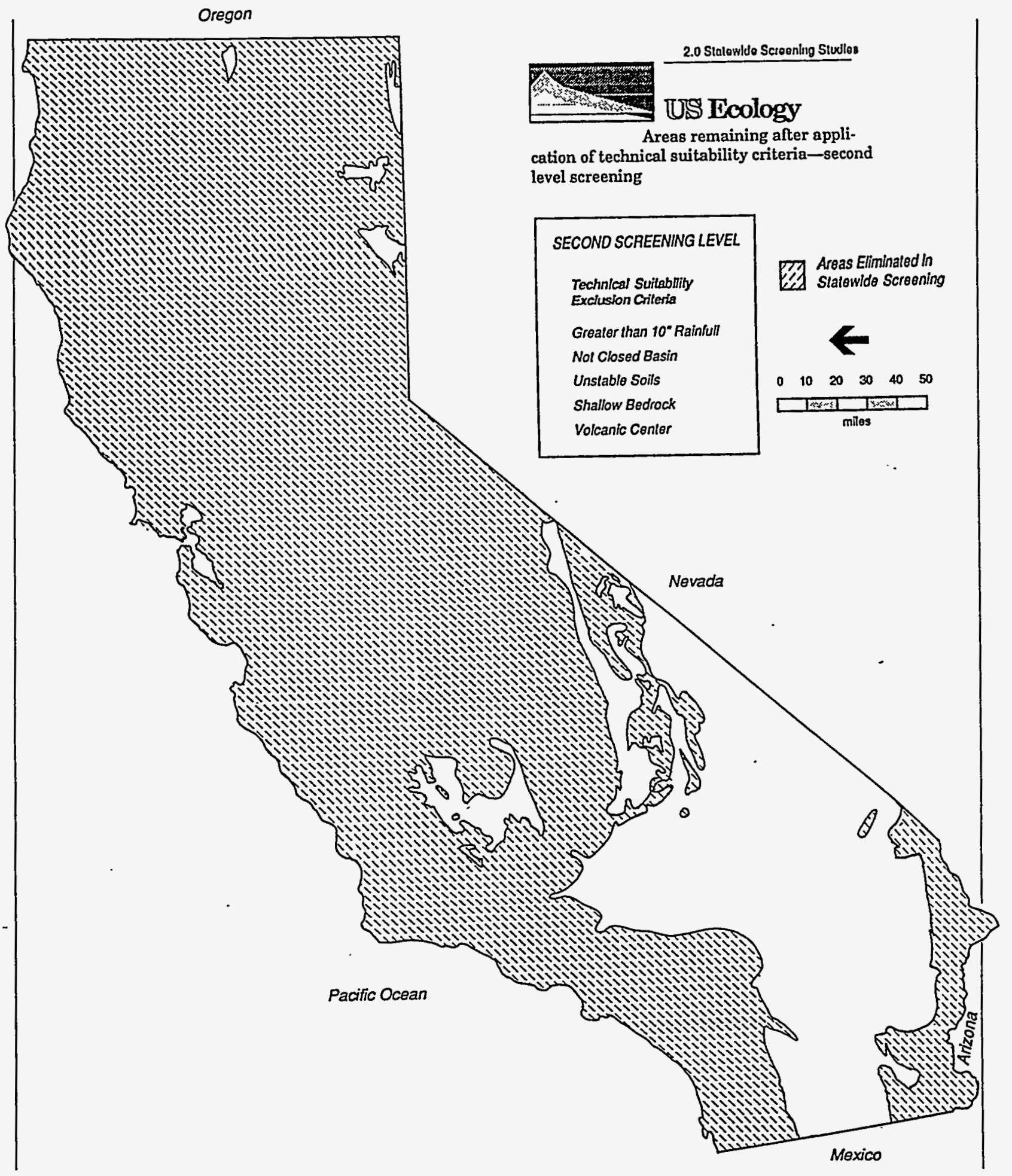

Figure 3. Areas remaining after application of technical suitability criteria-second level screening. 

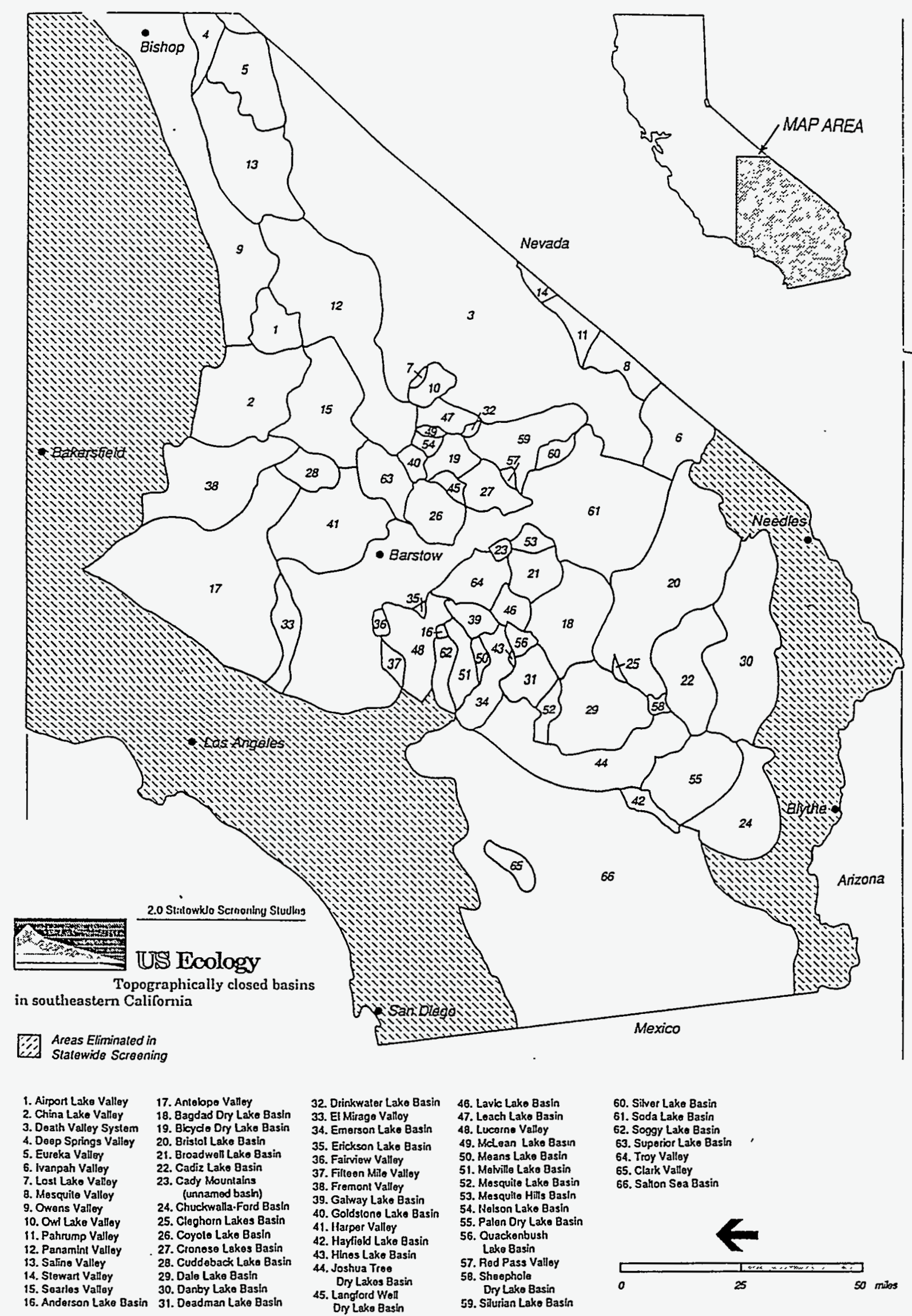

60. Sivet Lake Basin

61. Soda Lake Basin

62. Soggy Lake Basin

63. Suporior Lako Basin

54. Troy Valley

65. Claik Valley

66. Salton Soa Basin
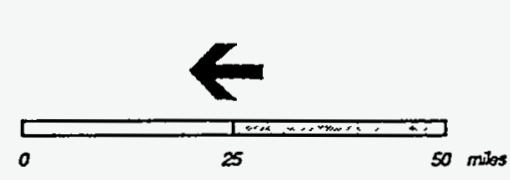

Figure 4. Topographically closed basins in southeastern California. 
- Potentially unstable sand deposits are present in the southeastern portion of the valley.

- Hotsprings are present in the northeastern portion of the valley and are part of the Wendel-Amede KGRA. This is indicative of volcanic hazards."

The few closed basins that were located outside the southeastern part of the State were eliminated in this step, leaving 18 basins in three large but contiguous counties. Although not itself a factor in eliminating basins from further consideration, this outcome probably allowed for some simplification of the techniques by which extensive public participation was used in subsequent steps to identify specific sites.

\subsubsection{Public Participation in Developing Area-Level Criteria}

At this point in the process, US Ecology called upon a Citizens Advisory Committee (CAC) formed by the League of Women Voters to assist in identifying a supplementary set of criteria based on the priorities of area residents. Input from a series of public meetings in 1986 and from the CAC were translated by US Ecology into measurable exclusionary and discretionary criteria. A document prepared by US Ecology describes the early stages of the process:

The issues and concerns expressed in the public's comments were identified as 'factors' for consideration in siting. Fifty-six factors were identified. They were categorized into 11 topical groups simply labeled as: (a) planning, (b) land use, (c) population and economics, (d) transportation and access, (e) community services, (f) recreation, (g) geology, (h) hydrology, (i) climate and air quality, (j) biological resources, and $(\mathrm{k})$ cultural resources. The factors were presented in a table to the CAC as simply-expressed issues. For example, the compatibility of the LLRW facility with agriculture was stated as the siting factor, 'Agricultural Use.' Some issues were more complex and the identification of siting factors required separation of the components of the issue; for example, concern about groundwater contamination was broken into 'Groundwater Depth','Groundwater Quality', and 'Distance to Wells.' The CAC were given information relating to which of the siting factors must be regarded as exclusionary based on the technical suitability requirements of 10 CFR 61 . The CAC then filled in a table which indicated if other factors should be regarded as high avoidance and distinguished between the factors that should be regarded as either a constraint or an opportunity (for siting). California Low-Level Radioactive Waste Disposal Facility Candidate Sites Selection Report, US Ecology, Inc., [n.d.], p. 3-7.

Based on the results of public questionnaires and public comments over several meetings, the CAC also provided US Ecology with its rating of the importance (high, moderate, or low) of each of the discretionary criteria. US Ecology adopted the ratings for application in the process.

\subsubsection{Area-Level Screening}

Beginning at this phase in screening, basins as whole units were no longer excluded. Instead, land area within each of the 18 basins was subjected to exclusionary screening in several steps. To do so, composite maps were drawn by considering criteria-related information on a number of 
source maps. The first step was to reapply the preestablished exclusionary criteria for which area-scale data were available. This eliminated large areas, including dry lake beds, earthquake hazard zones, mountainous perimeter areas of basins, and a number of culturally and environmentally significant areas. To the areas remaining, US Ecology then excluded additional land based on application of two new exclusionary criteria that had been developed by the CAC through the public participation process. These were wilderness study areas of the BLM and cultivated areas. This left about $1,300 \mathrm{mi}^{2}$ in Inyo, Riverside, and San Bernardino Counties for consideration. Areas ranged in size from several square miles to hundreds of square miles (see Figure 5).

\subsubsection{Preference Screening Using CAC Criteria}

The objective at this step was to narrow the search to specific "candidate siting areas" by considering the presence of "discretionary factors," including both preference and avoidance criteria. Because of the large number of criteria, data representing the criteria were digitized into a GIS at a scale of 1:62,500. The system allowed visual displays of the presence or absence of siting factors, and displaying composites of more than one factor.

Specific candidate siting areas were selected by examining the sum total of avoidance and preference factors in the area or in proximity to the area, as well as the relative importance of the factors (high, medium, or low). For example, the presence of an avoidance factor of high importance might result in exclusion of the area, while the presence of a single avoidance factor of low importance might not eliminate the area, if other conditions were favorable for siting. In some cases, land area was also excluded where a major constraint, not located on the land itself, affected its desirability for the proposed facility (such as poor access because of a mountain range). In this sense, US Ecology used the GIS as a tool to assist professionals in making judgments, rather than delegating formal decisionmaking responsibility to the computer system. Figure 6 shows the 16 candidate siting areas identified during this level of screening.

\subsubsection{Comparison of Candidate Siting Areas}

At this stage, the CAC was asked by US Ecology to conduct a structured exercise whereby the 16 sites would be grouped with respect to the siting criteria into the top five, middle six, and bottom five. The CAC was provided additional site-specific information, including the results of consultations with State agencies, detailed maps, information on population migration, transportation access, land use, and archeological and cultural resources. The results of the exercise were intended by US Ecology to be advisory in nature, to be considered along with information about public acceptability of the alternative sites in arriving at a decision. None of the sites was rated in the top five by all $12 \mathrm{CAC}$ members. Of the 16 sites, the Ward Valley site and the Silurian site were rated among the top five more often than any of the other sites, by 11 and 9 members, respectively.

US Ecology relied upon three primary sources of information to evaluate public acceptability of the 16 sites. These were input from the CAC, direct input from a series of public meetings in the area, and expressions of support or opposition to specific sites from representative bodies. 


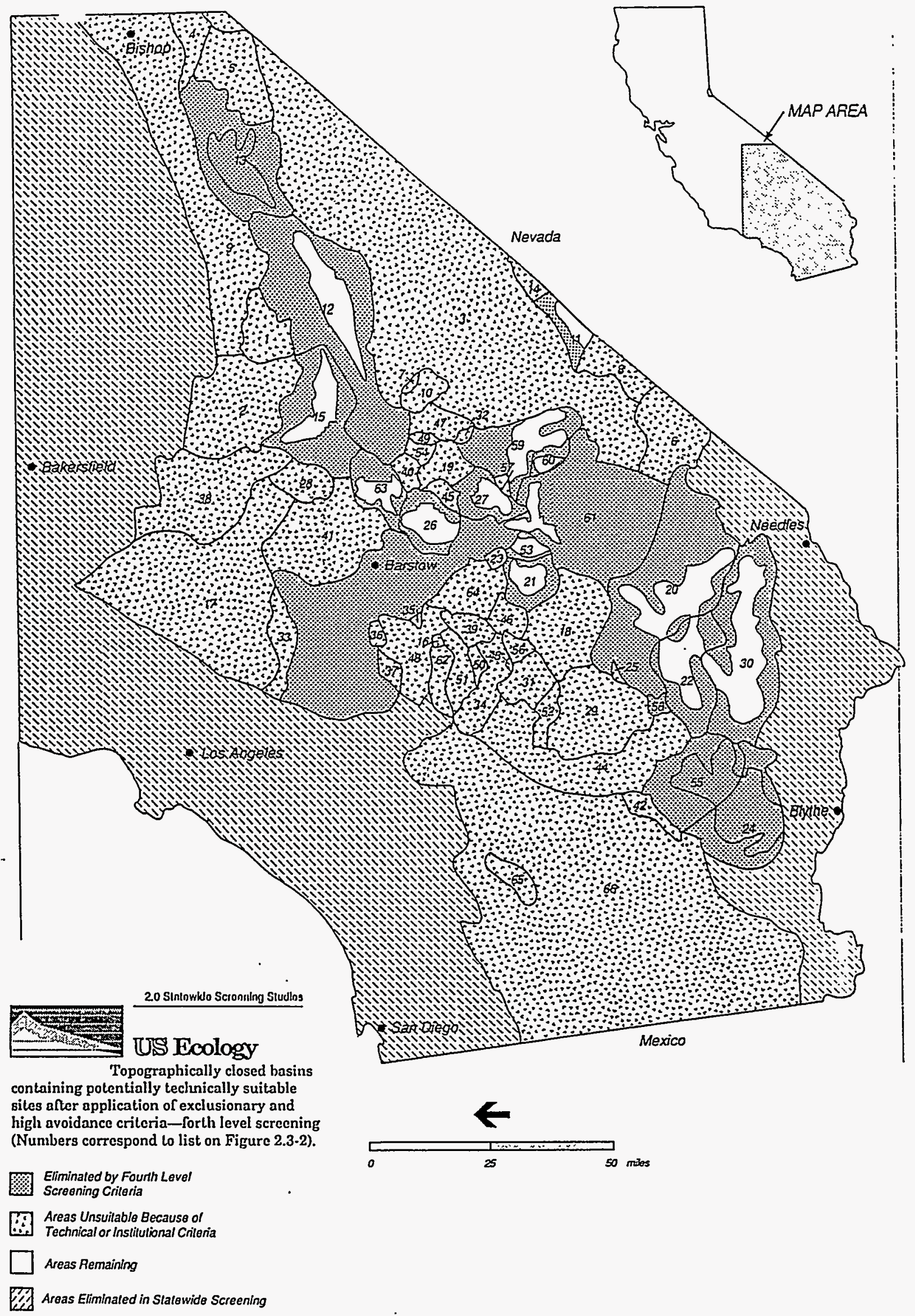

Figure 5. Topographically closed basins. 


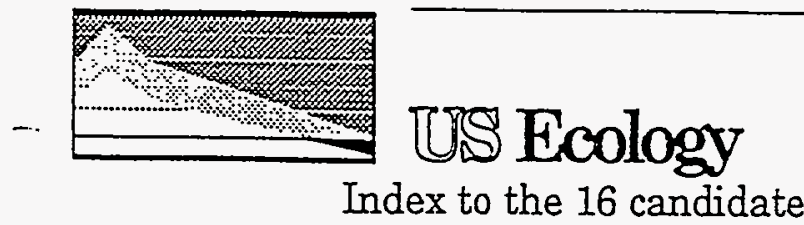

siting areas

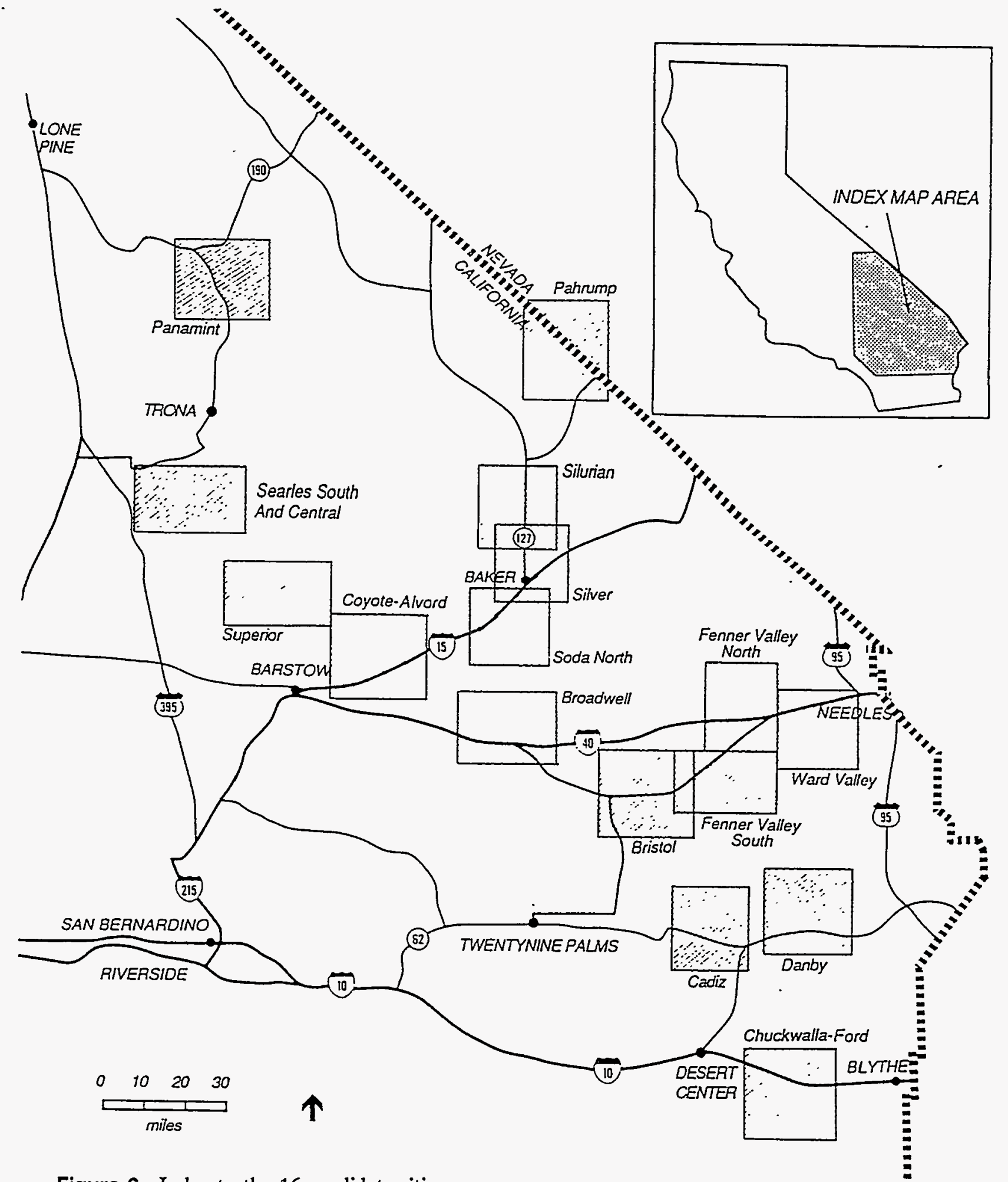

Figure 6. Index to the 16 candidate siting areas. 
Based on the information, US Ecology in February 1987 named three candidate siting areas (CSAs) for detailed site-specific evaluation: (a) the Ward Valley, (b) Silurian, and (c) Panamint CSAs.

\subsubsection{Screening the Candidate Site Areas}

To ensure diversity in the field of candidate sites, US Ecology decided to orient the siting process toward identification of one site in each of the three CSAs. The objective at this stage was to reduce the amount of land under consideration in each of the three CSAs to approximately $4 \mathrm{mi}^{2}$. This was a qualitative exercise in which US Ecology project managers considered a wide range of factors. These included technical favorability, good access, and flexibility in acquiring land parcels. Information from both mapped sources and from ground and air reconnaissance was considered.

From the most technically favorable areas with good transportation access, US Ecology sought areas where contiguous parcels had one owner, in order to simplify potential land acquisition. Negotiations with Santa Fe-Pacific Land Company were unproductive because the company wanted to sell a larger tract than necessary for the disposal facility and buffer zones. State school lands did not appear to offer the most favorable technical characteristics and ease of transportation access. As a result, each of the parcels finally identified by US Ecology was located on land managed by the BLM (Candidate Site Selection Report, p. 3-78, 79).

\subsubsection{Identification of Candidate Sites}

From each of the three 4-mi ${ }^{2}$ parcels, US Ecology selected 1-mi ${ }^{2}$ "candidate sites." Surface hydrology was the main consideration at this stage. Factors included: (a) topography, (b) drainage areas and patterns, (c) flooding potential, (d) erosion potential, and (e) suitability for implementing flood controls. US Ecology also conducted preliminary surveys of ecological resources. Detailed area maps and extensive field reconnaissance were involved in delineating the placement of the 1-mi grids.

These three candidate sites underwent detailed site characterization to determine the preferred site (a report on comparative approaches to site characterization is planned for this series).

\subsection{Final Site Selection}

In March 1988, following detailed site characterization of three candidate sites, US Ecology selected the Ward Valley site as the preferred site. The selection was made by US Ecology after consideration of the results of site characterization, input from the $\mathrm{CAC}$, and input from local advisory committees established by the League of Women Voters. A backup site in the Silurian Valley was also selected. The primary attributes favoring the Ward Valley site are:

- Greater depth to groundwater

- Better transportation access 
- Existing electrical power

- Gentler slope

- Greater distance to known earthquake faults

- Smaller upgradient watershed area. 


\section{CONNECTICUT-NORTHEAST COMPACT REGION}

Connecticut and New Jersey comprise the Northeast compact region. Deadlocked over which of the two member States should be first to host the regional facility, the Compact Commission in December 1987 designated Connecticut and New Jersey to develop and operate disposal facilities concurrently. Connecticut enacted enabling legislation in July 1987, making the Connecticut Hazardous Waste Management Service (Service) (an existing agency for promoting appropriate management of hazardous waste) responsible for selecting a site location for the lowlevel radioactive waste disposal facility. The Connecticut Siting Council is responsible under the law for regulating the siting process and issuing a "certificate of public safety and necessity" for the facility.

\subsection{Status}

Battelle Memorial Institute and subcontractor Atlantic Environmental Services, under contract to the Service, completed a statewide site screening program and recommended eight potentially suitable sites. In June 1991, the Service selected three of the sites to undergo characterization. Site-specific activities were suspended pending an independent quality review of the site screening process. The quality review of the site screening process was completed in January 1993 by TRC Environmental Corporation, under contract to the Service. Some of the issues raised by the review are discussed in the sections that follow.

In response to growing opposition to the candidate sites, the State in May 1992 enacted Public Act 92-45, which redirected the siting program. Under the new law, the Service was required to:

- Terminate all activities associated with the 1990 site selection plan

- Submit a new management plan (including siting criteria) to the General Assembly by February 1, 1993

- Commence a procedure to select "a contractor to conduct the new site selection."

The law nullified the results of the site screening and the plans to characterize the three candidate sites. The new management plan completed in January 1993 features a volunteer town approach to siting the facility. The volunteer approach set forth in the plan provides that only towns that want to participate in the process will be considered, and that a proposed site be approved in a town-wide referendum.

The remaining sections of the report on Connecticut's siting process focus on the initial site selection process. 


\subsection{Legal and Regulatory Framework}

Connecticut's initial site development law, P.A. 87-540, became effective upon Connecticut's designation as a host State for a regional disposal facility, December 23, 1987. As enacted in 1987, the law directed the Connecticut Hazardous Waste Management Service to identify four candidate sites for the disposal facility. It was amended the following year to require the Service to "evaluate and select one or more potential sites for a regional low-level radioactive waste facility."

The law requires the Service to select a firm in the private sector to prepare necessary license and permit applications and, to operate the facility. It also contains a provision precluding the license designee from having participated in the selection of the site. Siting organizations in North Carolina, Michigan, New York, and Illinois adopted a similar approach as a matter of policy, but not pursuant to a State law.

Prior to being amended in 1992, Connecticut's law required that a form of the top-down screening method be used to identify the site for the disposal facility:

In selecting each potential site, the Service shall use a process of site evaluation which considers generalized areas initially derived by applying a broad level of analysis ... The Service shall establish a continuing process of technical refinement of such areas based on more detailed levels of technical analysis of the (applicable criteria) (Section 22a-163d).

At the same time, the law provided that, "Any person may offer a land area for consideration as a potential site. Any such land area shall be evaluated by the Service with the criteria used for evaluation of any site."

The law also gives the Connecticut Siting Council authority to issue further directives on siting through formal rulemaking processes. Under the law, the Council shall adopt regulations they deem necessary to carry out the law, including regulations for the siting of regional low-level radioactive waste facilities. The Council consists of designees of the Department of Health Services and the Department of Public Safety, and members appointed by the governor and legislative leadership. The siting regulations adopted by the Council (Section 22a-1631-1, Site Selection Plan, A-14) are limited to site requirements or criteria, and do not elaborate on the method or process for siting that is outlined in the statute.

Although not an agreement State, Connecticut law vests the Siting Council with authorities that, in many respects, parallel the authority of the NRC to license and regulate the disposal facility. Before construction of the disposal facility can begin, the developer must receive a "certificate of public safety and necessity" from the Council, a process that can take 12 or 18 months under the law. Thereafter, the facility is required to be operated in conformity with the certificate. To obtain the certification, the applicant must submit information relating to site selection, land use, risk assessment, financial assurance, management of site operations, and plans for closure and stabilization of the site. The applicant must also submit a copy of the NRC license application and environmental reports to the Council for review. The Council evaluates the information through adjudicatory-style hearings. 


\subsection{Siting Criteria}

In order to receive a lieense from the NRC. the site must meet the general requirements in 10 CFR Part 61.50), "Technical Requirements lor Land Disposal Facilities."

In order to receive a "eertificate of public safety and necessity" from the Siting Council, the site must meet additional requirements issued in the form of regulations by that body. The Council's site requirements are generally in the form of proscriptions. For example:

The active parts of the proposed facility shall not be located in any of the following arcas ... Arcas with slopes greater than 15 percent subject to instability including, but not limited to, the geologic process of mass wasting, slumping, landsliding, and gully crosion.

Sume of the regulations decmed necessary by the Siting Council are similar to those that had already been codified into Federal regulations by the NRC. the ageney responsible for evaluating the lieense application against the Federal requirements. For example, the State regulations prohibit siting in an area "that could adversely affect the ability of the site to meet the pertormance ubjectives of 10 CFR Part 61."

Bused on site requirements in Federal regulations, the regulations of the Siting Council, and wher requirements impesed by various State laws and regulations. the Hazardous Waste Management Service developed a set of 94 specific criteria. The criteria were divided into three caltegories for purposes of application. As described in the Site Selection Plan, these are:

- Exclusionary-If the characteristic is present, the site is unacceptable

- Avnidance-To be implemented as an exclusionary critcria, unless there is a compelling reason to consider the site in spitc of the characteristic

- Preference-A desirable, but not necessary, characteristic.

The site selection eriteria were also divided into 15 broad subject areas. At the request of the Buard of Directors of the Service, the Low-Level Radioactive Waste Advisory Cummittec. a committee established by law with members appointed by the governor and legislative leadership. ranked each subject area as to its relative importance to screening. The subject areas were ranked as indicated in Table 1. The number in parenthesis is the number of criteria in each subject arca.

The Sitc Selection Plan designated the step or steps at which cach critcrion would be applied. In general, selected exclusionary and avoidance criteria were applied during all screening stcps, using data sets applicable to the particular scalc of screening. Avoidance criteria were appliced as though they were exclusionary, with the caveat that excluded areas could be revisited if necessary. Preferential criteria for which data were available were applied during the latter stages of screening to cvaluate and compare sites not previously excluded. 
Table 1. Subject area ranked.

$\begin{array}{ll}\text { High rank } & \text { Water quality (6) } \\ & \text { Hydrogeology (16) } \\ \text { Geology (8) } \\ \text { Hydrology (3) } \\ \text { Memography (5) } \\ \text { Transportation (2) } \\ \text { Site size (3) } \\ \text { Medium-high rank } & \text { Land use (33) } \\ & \text { Natural resources (2) } \\ & \text { Environmental resources (3) } \\ & \text { Habitat areas (4) } \\ & \text { Site acquisition cost (1) } \\ & \text { Culturalaesthetic (5) } \\ & \text { Air quality (1) }\end{array}$

\subsection{Site Selection Process}

The governing board of the Service made a critical decision early in the site screening process. In order to avoid accusations that had been raised in other States that candidate sites had been selected based on personal or political considerations, Battelle and its sereening subcontractor. Allantic Environmental Services, were directed not to release maps showing the results of interim screening steps. Instead, the members of the board would be presented with physical descriptions of finalist sites, and would be required to select the finalists without knowledge of their locations within the State. Thus, although the Site Selection Plan specified that sereening be done in three distinct phases, interim results of these phases could only be released after the final decision had been made on locations of the candidate sites. The screening stcps wcre as follows:

1. Statewide screening to identify areas in Connecticut that contained potentially suitable sites.

2. Area-wide screening and evaluation of any volunteered land areas to identify a number of potentially suitable sites.

3. Evaluation and comparison of potentially suitable sites to identify three candidate sites for charactcrization.

While the purpose of this strategy was to avoid creating the perception that inappropriate considerations had influenced the selection of sites, the decision not to release interim results also allowed the screcning to be completed more quickly. From start to finish. Connecticut identified three specific sites for characterization in seven months, a shorter period of time than any of the 
other States engiged in identilication of potential sites for low-level radioactive waste disposal lacilitics.

To sereen the State, Batlelle used AutoCAD soltware to process information and gencrate outpul. AutoCAD is a computcr-aided design and graphics systcm, one of whose capabilitics is the manipulation of digitieed data to gencrate maps. For purposes of screening, it can serve the same lunctions as GIS soltware such as Arc/Info. A digital map of the State obtained from a State agency. was used as the base map for overlaying data.

Bcfore initiation of site screening, the contractor identified data sources that it intended to use to represent the 94 criteria. In the majority of cases, the data existed in mapped format, but needed to be converted to digital format by the contractor for application in the screening system (a spin-off from the project that was of potential benelit to land use planners for other applications). In some casces. data sets were already in the standard digital format and ready for direct application. Some data sources intended lor possible application in the latter stages. evaluation and comparison of specific sites. were not digitized into the computer system since they could be applied just as easily for that purpose through manual techniques.

Step 1. Statewide screening. During statcwide screcning, 15. exclusionary and 2 avoidance eriteria were applied. Excluded were lands that are sources of or watersheds for public drinking water supplics. protected aquifers. major watcrcourses, river conservation zones. $1(0)$-ycar moodplains, coastal storm surge areas. Statc parks and forests, historic places and districts. urban centers. rural community centers, urban growith arcas, and existing presended open spaces. Stalcwide screening eliminated approximately two-thirds of the State's land arca (sce Figure 7 ).

Step 2. Area-level screening. During this stcp, data representing two cxclusionary and six avoidance critcria were applied to the areas remaining after the statewide screening. Excluded were State and Federal wetlands, arcas with less than 160 acres, certain agricultural lands. municipal forests, and municipal open spaces.

During this step. in November 1990. the Service sent a letter to towns and potentially interested parties soliciting voluntecred lands. The solicitation resulted in eleven areas as possible volunteer sites. Or these, unly two were located in areas that had not been previuusly cxcluded in statewide or area level screening. The remaining two were located in land eliminated in Step 3 under the criterion to prefer land with slope less than $15 \%$.

Figure 8 shows areas remaining after the area-level screening. Although only $11.5 \%$ of the State remained unexcluded, the land area was widely dispersed throughout the State in hundreds of small, irregularly shaped parcels. (Other States had avoided this result due, in part, to more diverse physical characteristies that allowed broad-brush exclusions of large contiguous arcas, and due to delibcrate decisions to include or exclude towns or countics as whole geopolitical units.)

Step 3 (earlier stages). This step involved the reduction of the number of siting areas under consideration. Additional exclusionary and avoidance critcria applied at this step removed arcas of known natural resourecs, critical habitats for threatened and endangered species, lands with a scasonal high water table, projected population growth. and ancient burial places. Hundreds of small areas, however, representing some $7 \%_{0}$ of the State's land area, still remained. 


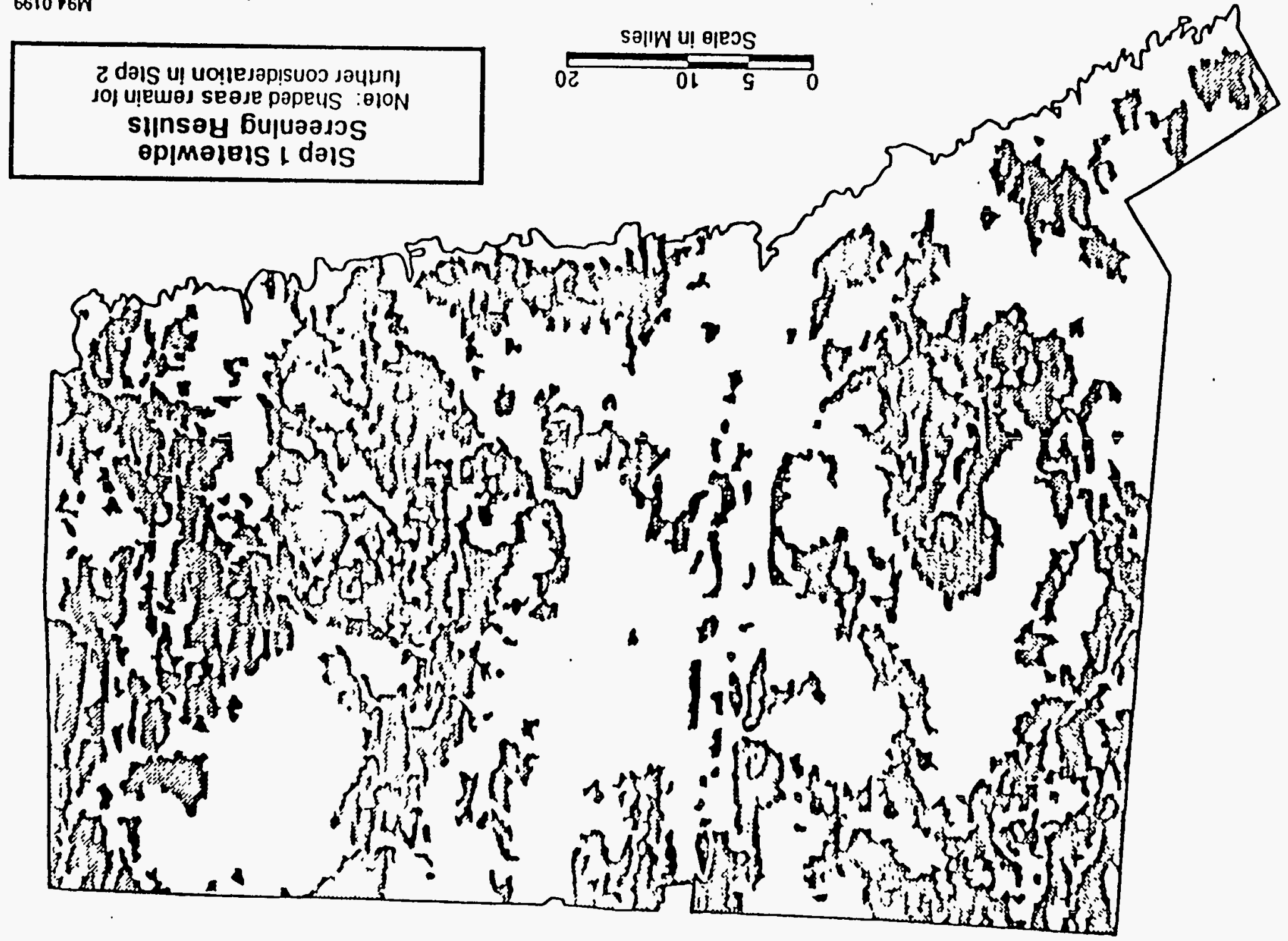




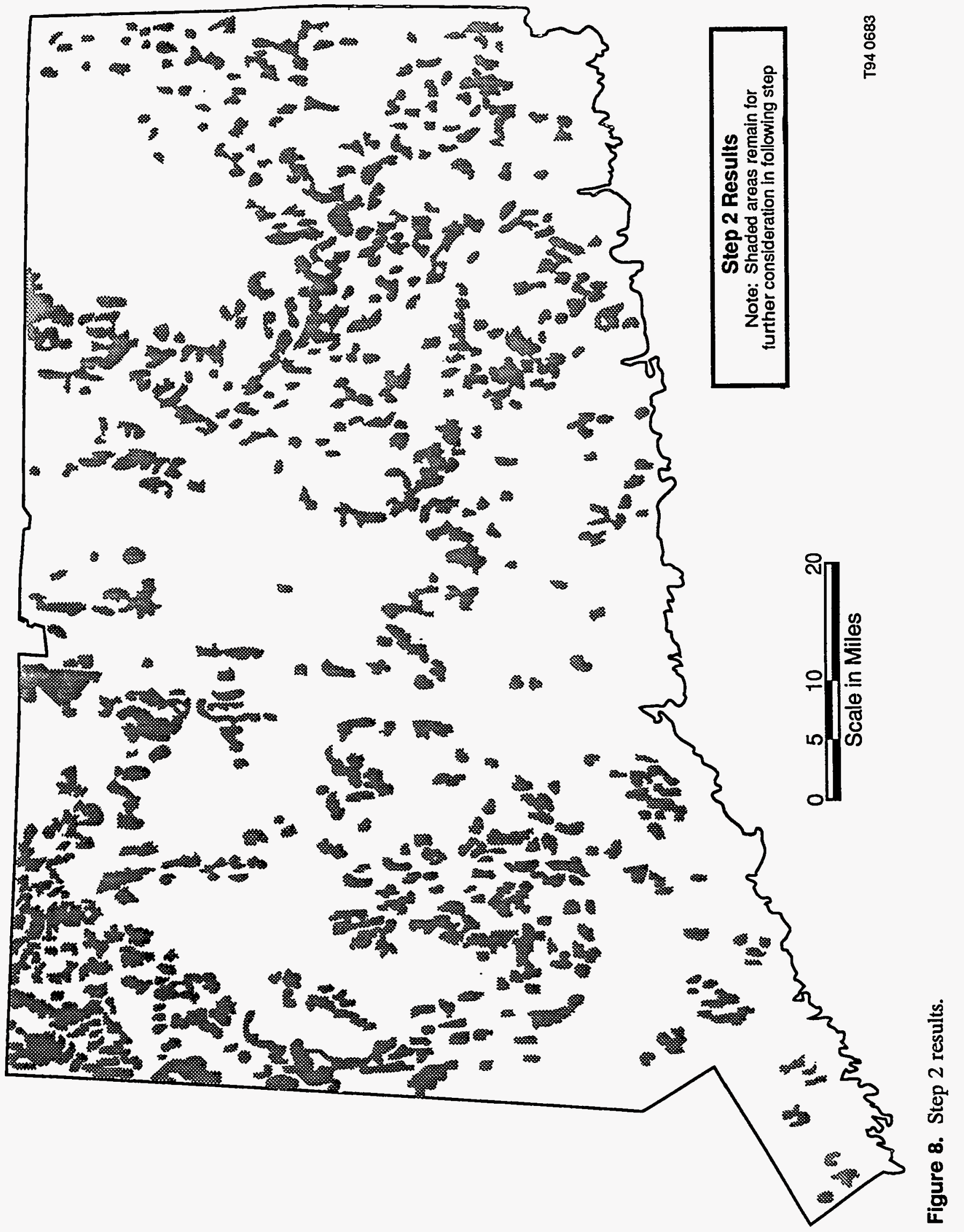


In order to meet the goal of selecting a limited number of specific sites, the Service decided to apply the preference criterion for preferring land with less slope. Originally, the criterion was intended for use not as a screening factor, but as a site-specific consideration for comparing a limited number of competing sites. To apply slope as a screening criterion, the Service directed the contractors to examine remaining areas against Soil Conservation Service soil maps, a surrogate source of data, to identify and "defer" land with slopes greater than $15 \%$. As shown in Figure 9, this application reduced the number of small contiguous sites to 45 . With a more manageable number of sites for which site-specific information could be obtained, the Service's siting contractors reduced the number to 28 .

At this stage, the process shifted from exclusionary or avoidance screening of land area, to comparative evaluation of the remaining areas using the long list of preference criteria. Over two workshops, a technical panel consisting of staff of the Service and the contractors conducted a grading-scoring exercise to provide a basis for comparing the siting areas. For each of the preference criteria rated for which data were available, the panel rated each of the 28 siting areas. A single value of $\mathrm{A}, \mathrm{B}$, or $\mathrm{C}$ was awarded by the panel as a whole, depending on how well the siting area met the criterion. Table 2 is one sample page from the matrix comparing three of the sites against several of the criteria. For cumulation of aggregate scores, the $A, B$, and $C$ grades were converted to scores of 3,2 , and 1 , respectively. In the first workshop, the participants considered only the criteria rated "high" or "medium-high" by the Advisory Committee (see above). In the second workshop, criteria of "medium" rank were considered. Based on the results from both workshops, the staff of the Service recommended eight siting areas to the Board for its consideration.

Step 3 (later stages). Selection of three sites for characterization. The site selection plan called for the siting contractor to recommend three candidate sites to the Board for its approval. However, the Board wanted to be more actively involved in the final stages of site selection, and held an open two-day workshop to select three from the eight recommended sites to undergo characterization. At the same time, the Board wanted to avoid accusations made in other States that the final selection had been based on considerations other than those in the published criteria. To reconcile the two objectives, the Board asked the staff and contractors to present information about the eight sites in a manner that would not reveal their locations within the State.

During the first day of the Board's workshop, the Board reviewed the data sources for the criteria, the grading standards, and the grades prepared in the staff and contractors' previous workshops. Because aggregate scores of the eight recommended sites did not vary significantly, the Board decided to consider and compare subtotals of the scores for different categories of criteria. These categories were:

- High ranked criteria in the areas of water quality, hydrogeology, geology, and hydrology.

- Medium-high ranked criteria in the areas of demography and transportation. 


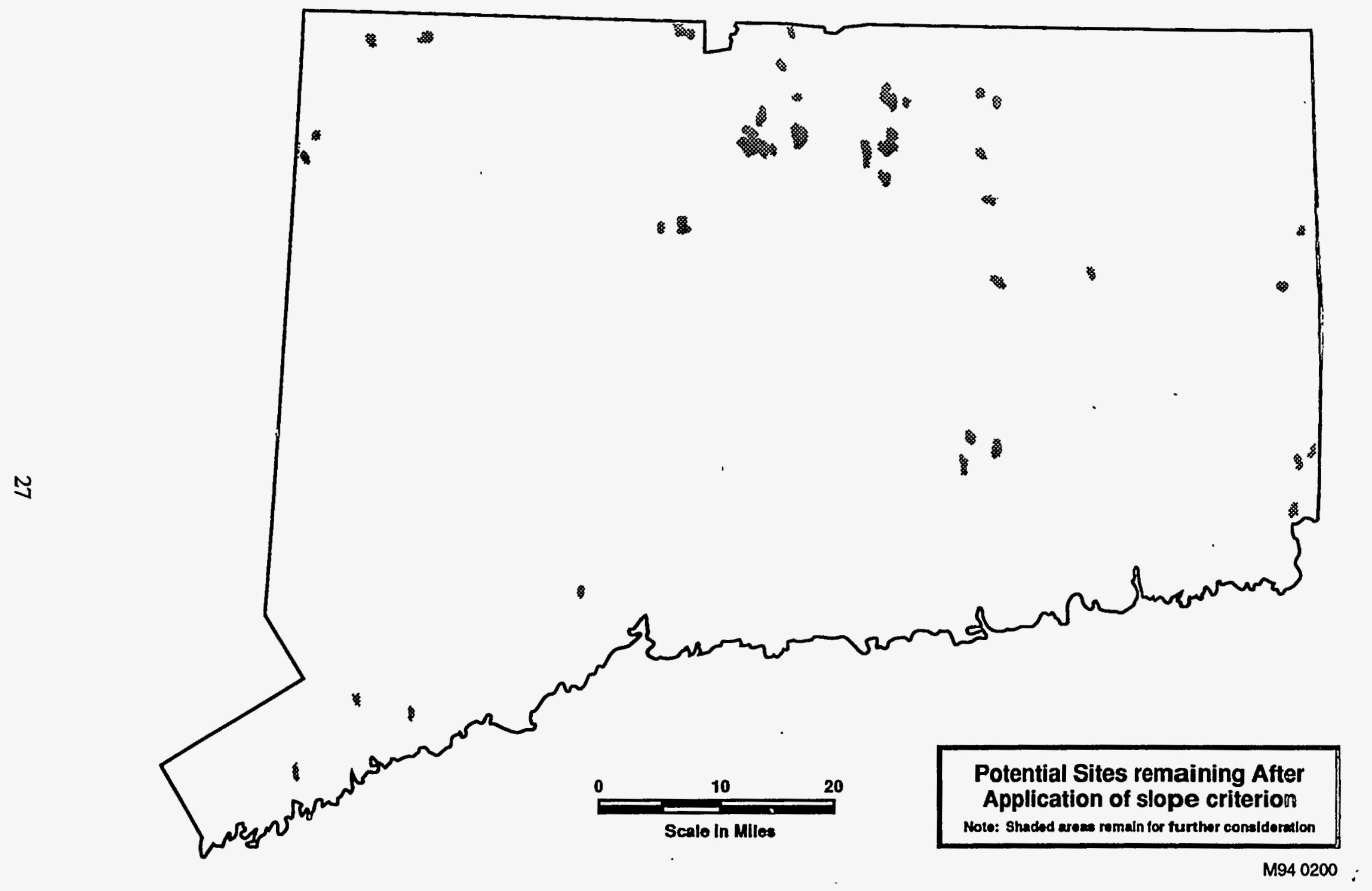

Figure 9. Potential sites remaining after application of slope criterion. 
Table 2. Data matrix for panel workshop two.

No. Site selection criteria Water Quality

6 Prefer: Minimum impact to water sources $(4 \mathrm{E} 2,5 \mathrm{~F} 3)$

Hydrogeology

8 Prefer: Easier for hydro modeling for NRC and EPA (2B2, 6A2)

9 Prefer: Hydro units "not highly vilnerable" (6F1)

Geology

13 Prefer: Stable foundation materials (6D1, 2A3)

Geology-Retardation of radionuclides

14 Prefer: Better retardation of radionuclides (2A1)

$\begin{array}{ll}\text { A Public Well } & 1.6 \\ \text { GAA } & 0.9 \\ \text { AA } & 0.9\end{array}$

C Southern half of site is sand and gravel. Northern half is a mixture of thin and thick till. Difficult to model.

C Southern half of site on sand and gravel. Short travel time.

C Southern half of site on delta (river mouth) deposits. Northern half on till with slopes. Landslides in same material $1 \mathrm{mi}$ away.

C Southern half of site on sand and gravel. Poor retardation capacity.

A Site not in Moodus area

C Number of watercourses $>1$, distance from site: bordering

B Upland watershed, 9.4 acres

C 100-year floodplain, elevation difference to site $10-20 \mathrm{ft}$.

A

\section{A Public Well}

GAA

AA

Stratified drift

C Site is underlain by relatively thin till over fractured bedrock. Difficult to model.

C Travel time through thin till and fractured bedrock possibly short.

B Till over marble, with karst features nearby. Uncertain foundation conditions.

B Thin till over fractured marble. Moderate retardation capacity.

A Site not in Moodus area

C Number of watercourses $>1$, distance from site: bordering.

A Hilltop, no upland area

C 100-year floodplain, elevation difference to site $10-20 \mathrm{ft}$

A
A Public Well

GAA

AA

Stratified drift

C Site underlain by thin till over marble, probably with fractures. Difficult to model.

C Site underlain by thin till over marble with fractures. Travel time may be short.

B Site on till over marble. Moderately poor foundation material. (Possible karstic features.)

C Marble probably has medium to poor retardation capacity.

A Site not in Moodus area

B Number of watercourses $>1$, distance from site: $100 \mathrm{ft}$

A Hilltop, no upland area.

A 100-year floodplain, elevation difference to site $50-60 \mathrm{ft}$

24 Prefer: Not in 500-year floodplain (11A1)

Hydrology-Coastal high hazard areas

26 Prefer: Farther from coastal storm surge $(2 \mathrm{~F} 6,3 \mathrm{E} 3)$ 
- Medium ranked criteria in the areas of site acquisition cost, land use, natural resources, adverse economic impact, environmental resources, habitat area, and cultural factors/aesthetics.

- Low ranked criteria in the area of air quality.

Divided this way, scores for four of the eight sites (sites A, C, D, and G) were clustered at a higher plateau for the high-ranked criteria than scores for the other four. Of the four more highly scored sites, site $\mathrm{G}$ scores lower with respect to the medium ranked criteria. Following consideration of this sensitivity analysis, the Board formally specified sites A, C, and D as the candidate sites on June 10, 1991. Later in the day, the staff of the Service announced the locations of the three sites that were within 2 mi of each other.

Independent Quality Review. Following discovery by the staff of the Service of two errors in application of the screening process, the staff contracted with another company, TRC Environmental Corporation, to conduct an independent review of the quality of the screening process. The review focussed on technical aspects of the screening exercise and did not address the general methodology or strategy adopted by the Service for identifying candidate sites.

Among the general findings, the report was critical of the lack of formal procedures for digitizing data, inadequate documentation of the source of data sets, the decision not to apply data that were not uniformly available across the study area, and selection of some data sets over others. Among specific comments, the report noted an insufficient measure of proximity (500-ft radius) away from community wells, and application of slope criterion in a manner that may have unnecessarily eliminated areas of sufficient size for the disposal facility. One of the more controversial recommendations was that the site screening process be conducted under a quality assurance program that complies with ANST/ASME NQA-1 (American National Standards Institute/American Society of Mechanical Engineers Nuclear Quality Assurance) standards, which were designed for site characterization of nuclear power plant sites. Noting that some imprecision is inherent in top-down screening methods, the staff of the Service and its contractors questioned whether the costs of implementing such procedures would justify any benefits.

In response to the quality review, the staff of the Service issued comments with general applicability to any State executing this kind of process:

Perhaps the most striking outcome of the quality review and the comments is that many issues remain concerning the level of accuracy that is possible with publicly available data in Connecticut, and how the data should be used in a statewide screening to attain an acceptable level of accuracy. (The Department of Environmental Protection) indicates that data of different map scales should not be overlaid in a statewide screening to achieve the best results, but Battelle and Atlantic indicate that the best available data appear in a variety of scales. Issues regarding the usefulness of publicly available data must be resolved for the State of Connecticut to undertake a successful statewide screening for siting public facilities. ${ }^{a}$

a. Memo to Board of Directors from Ronald Gingerich, Director, February 3, 1993. 


\subsection{Final Site Selection}

Connecticut did not select a final site, but instead revised its approach to site selection. Following tumultuous local opposition to the selected sites, Connecticut, in 1992, enacted P.A. 92-45, "An Act Concerning the Siting of a Low-Level Radioactive Waste Disposal Facility and a Temporary Monitored Retrievable Low-Level Radioactive Waste Facility." The law directed the Connecticut Hazardous Waste Management Service to terminate its site selection activities and develop a new waste management plan. Unlike its predecessor, the new law does not mandate a specific approach to siting.

The results of the top-down screening process convinced the Hazardous Waste Management Service that a site selected through such a method would be unlikely to win public support. A volunteer-town approach was developed by the Service after consultation with regional planning agencies, councils of governments and other organizations of local elected and appointed officials, the Low-Level Radioactive Waste Advisory Committee, and the general public.

The new plan features substantial benefits and incentives to towns that participate in the process. The Service will consider only sites that have been approved in town referendums. (The State of Connecticut is divided into townships.). Prior to a referendum in a town or regional group of towns, the Service will conduct a preliminary site suitability study to determine whether or not the site is likely to meet the site suitability requirements in State and Federal law and regulations, and any additional requirements established by the town. 


\section{ILLINOIS-CENTRAL-MIDWEST COMPACT REGION}

Illinois is the host State for the Central-Midwest compact region. Kentucky is the only member State of the compact region. The Illinois Low-Level Radioactive Waste Management Act was enacted in 1983. As originally enacted, the law made the Illinois Department of Nuclear Safety (IDNS) responsible for selecting a site for the disposal facility. The law was amended in 1985 to provide additional guidance and detail. IDNS proposed a site location near the volunteer town of Martinsville in January 1991. After controversy ensued at the State level over the selection of the site, the State in 1990 amended the law to create a three-member Illinois LowLevel Radioactive Waste Disposal Facility Siting Commission (Siting Commission) to approve or disapprove the site. The Siting Commission rejected the site and the review of the license application was never completed.

\subsection{Status}

In reaction to the rejection of the Martinsville site by the Siting Commission, the State in 1993 enacted new legislation amending the Low-Level Radioactive Waste Management Act. The amended law establishes a Task Group consisting of three State department heads and other citizens. The Task Group is required to develop a new set of siting criteria. Based on the criteria, the law requires the Illinois State Geologic Survey and the State Water Survey to conduct a top-down screening of the State to identify at least 10 possible site locations of at least 640 acres each. From these sites, a contractor under the IDNS is required to select the three "that appear most promising for development" of a disposal site. If the Task Group concurs that the three sites are likely to meet the siting criteria, then the contractor is required to select one or more for full characterization. The governor appointed many of the other members of the Task Group on December 30, 1993.

The remainder of this section describes Illinois' initial site selection process.

\subsection{Legal and Regulatory Framework}

The Illinois Low-Level Radioactive Waste Management Act (Ill. Rev. Stat., ch. 111 1/2, para. 241-1 through 241-24) contained few siting criteria. Several of the statutory criteria were general statements, which called for favorable site characteristics. Section 12(b) of the law, as amended, required that the site be located:

- So that public health, safety, and welfare be protected

- In a suitable geological and hydrological medium

- So as to minimize the possibility of radioactive releases into groundwater used for public water supplies

- $\quad$ Outside 100-year flood plains

- So as to consider transportation distances for the waste. 
As enacted in 1983, the law essentially provided veto authority to a "municipality" in which a proposed site was located, or one within 1-1/2 mi of a proposed site. Section 12(b) of the law provided that:

No low-level radioactive waste disposal facility shall be located in or within 1-1/2 mi of the boundaries of any municipality unless approval is given by the governing body of that municipality.

In the midst of the siting process, the law was amended in 1988 to add a similar veto authority for county governments for proposed sites that were more than 1-1/2 mi from any municipality. Section 12 (b) provided that:

No low-level radioactive waste disposal facility shall be located in an area of a county situated more than $1-1 / 2 \mathrm{mi}$ beyond the boundaries of a municipality unless approval is given by the governing body of that county.

The Radioactive Waste Management Act did not require that site requirements be promulgated through a rulemaking process. The law did, however, require that IDNS, in cooperation with the Illinois Geological and Water Surveys, conduct a study of technical considerations related to siting, including geologic and hydrologic conditions best suited for such a facility.

As a condition for becoming a NRC agreement State in 1987, IDNS adopted site suitability regulations substantially equivalent to those in 10 CFR Part 61.50. The regulations are in Title 32 of the Illinois Administrative Code, Part 601.230.

\subsection{Siting Criteria}

Exclusionary and "favorability" criteria were developed by the IDNS in consultation with the Illinois State Geological Survey, Illinois State Water Survey, Illinois State Natural History Survey, Illinois State Museum, and Illinois Department of Energy and Natural Resources. Eventually, three reports were issued that included site criteria.

As applied to a screening exercise, the purpose of siting criteria is to increase the chances that a site selected through such a method will meet technical requirements and performance objectives once onsite studies are conducted. Recognizing that GIS-based data representing site requirements can only approximate actual site conditions, IDNS limited screening criteria to significant core criteria for which relatively good data were available.

Based on the State law and Federal regulations, six exclusionary criteria were established. These were as follows:

- Areas with free-standing water

- Areas either exceeding earthquake intensity Modified Mercalli Index IX on bedrock or Modified Mercalli Index VIII on unconsolidated material 
- Designated federally protected lands

- Designated State-protected lands

- Areas prone to subsidence or landsliding

- Areas within a 100 -year floodplain.

Favorability criteria were divided into those that are performance-related and those that are not. Performance-related factors were considered more significant in determining the suitability of a site because nonperformance conditions are often more easily prevented, minimized, or mitigated. These factors were applied at a county level to select the potential candidate areas. Following are the seven performance-related favorability criteria:

- Areas of low permeability

- Areas of simple geologic structure

- Areas without surficial sand and gravel deposits

- Areas with low erosion

- Areas far from surface water supplies

- Areas without high-yield groundwater aquifers

- Areas without shallow aquifers.

Eleven nonperformance-related favorability factors were established. IDNS's 1988 Site Identification Plan and Status Report indicated that these 11 factors would be used, along with input from local governments, groups, and individuals, in selecting alternative sites. Examples of nonperformance-related criteria are:

- Areas without archeological, historical, or cultural sites

- Areas with as little prime farmland as possible

- Areas close to Federal and State primary roads.

\subsection{Site Selection Process}

\subsubsection{Identification of Counties to Undergo Evaluation}

The framework designed by IDNS for site selection was to perform exclusionary screenings of counties potentially interested in having the proposed facility. The solicitation of interest included mailings, personal contacts, briefings, and hearings. Counties were provided background information about the proposed facility and a description of the kinds of benefits and incentives 
available for hosting the facility. Although a county veto was not included in the State's low-level radioactive waste law during the initial phases of site selection, IDNS announced a policy that the site would not be located in a county that was opposed to having the facility. IDNS indicated that, if a sufficient number of counties expressed interest in the facility, it would limit further detailed evaluation to those counties.

Based on judgments about the likelihood of obtaining political support in the more technically promising counties, the management of IDNS selected 21 counties to undergo more detailed screening and evaluation. Two counties were later added to the group.

\subsubsection{County Screening}

To screen the 21 counties and generate composite maps, IDNS's contractors, Battelle Memorial Institute and Hanson Engineers, used a relatively simple method. Areas that included exclusionary criteria were considered "excluded areas," while areas that did not meet all seven of the performance-related favorability criteria were considered "areas difficult to license." The remaining areas were "candidate areas." The January 1988 report, Site Identification Plan and Status Report, contained maps that presented the results of the county screening. Figure 10 is a black and white reproduction of the color map for Clark County. Following publication of the screening results, six of the 21 counties notified IDNS that they no longer wanted to be considered. As the site selection process progressed, a total of 17 counties indicated that they no longer wanted their unincorporated areas to be considered. Four others were eliminated by IDNS for technical reasons.

\subsubsection{Site Selection}

A month prior to issuance of the Site Identification Plan and Status Report, the Illinois LowLevel Radioactive Waste Management Act was amended to grant counties formal power to veto site locations that were 1-1/2 mi outside a municipality (see Section 4.2.). The new provision was not as broad as the previous IDNS policy in that it did not give counties veto power if the site was located in or near a municipality within the county.

The combination of the amendment to the law and the release of county screening maps precipitated increased discussion and debate within the remaining counties regarding their willingness to host the facility. As it became apparent that many county governments would likely vote to formally withdraw their nonmunicipal land from consideration, the town of Martinsville, in Clark County, signalled increased support for locating the facility within the county, if not in Martinsville itself. In January 1988, the Martinsville City Council voted unanimously to endorse locating the proposed facility in Clark County. The following day, the Clark County Board voted four to three to withdraw the county from further consideration.

With the withdrawal of nonmunicipal areas of Clark County (and withdrawal of each of the other remaining counties), IDNS siting officials began a more specific investigation of the town of Martinsville, and established a field office in the town. In February, the Martinsville City Council voted unanimously to ask IDNS to determine whether the site could be located in or within $1-1 / 2 \mathrm{mi}$ of the town. Following an intensified two-month study, involving limited drilling, field reconnaissance, and investigation of land records, IDNS in March 1988 announced selection of a 


\section{Plate 5}

\section{Composite Favorability \\ Clark County}

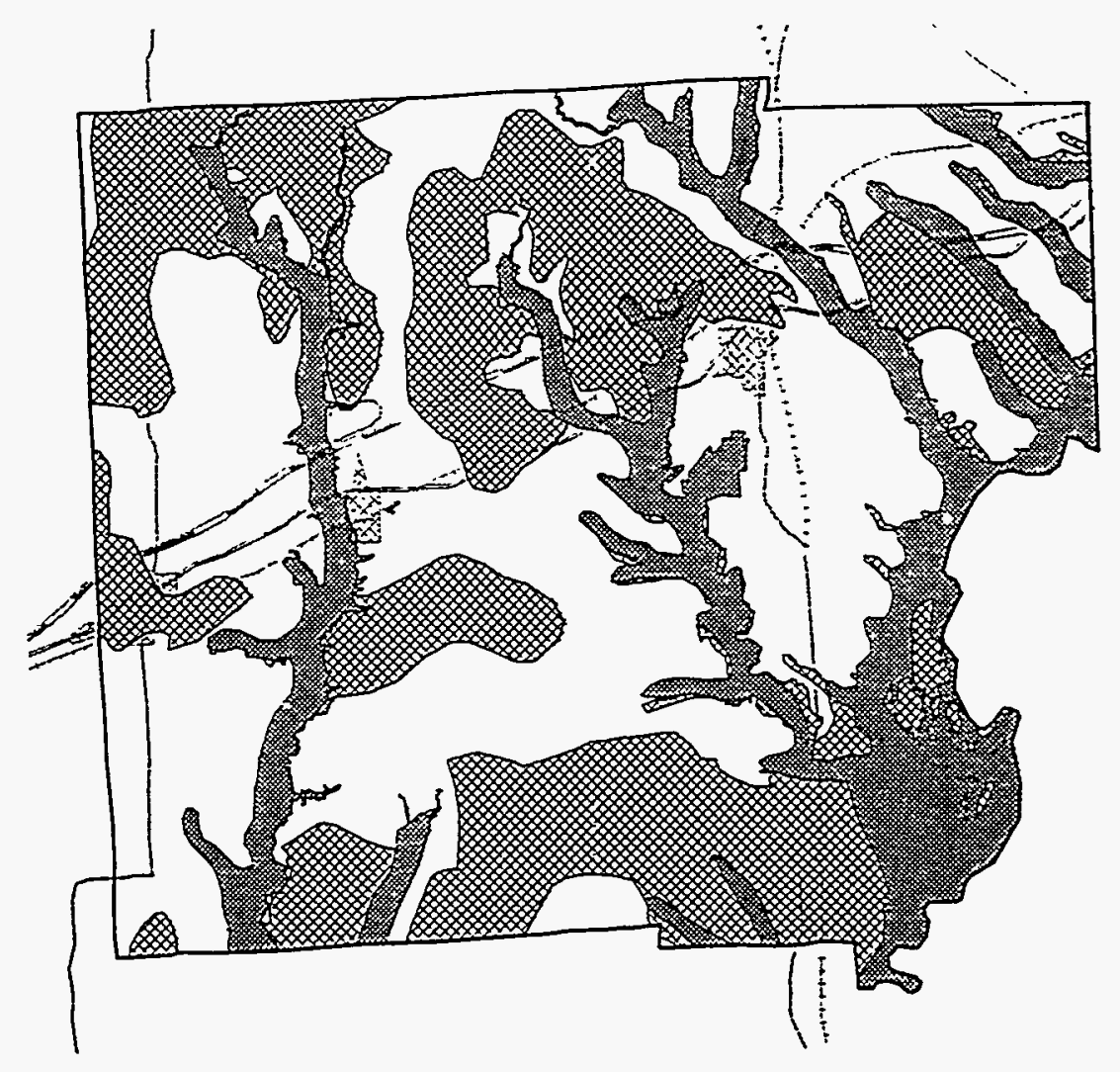

Candidate Areas

Areas difficult to license

Excluded Areas

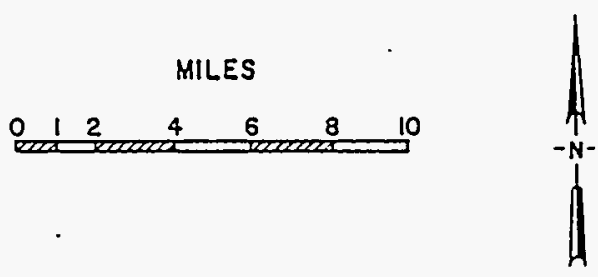

Figure 10. Composite favorability Clark County. 
potential site north of Martinsville, within the town's 1-1/2 mi zone of jurisdiction. In June, another alternative site was selected about 9 mi south of Martinsville (the "Martinsville South" site). If the site had been selected, Martinsville planned to strip annex out to the site.

As IDNS began to focus selection of alternative sites on the Martinsville area, Wayne County requested IDNS staff to provide briefings on the project. Having been preoccupied up to that time in establishing a regional sanitary landfill, Wayne County had neither asked to be considered for the low-level radioactive waste disposal site, nor withdrawn from consideration. In March 1988, the County Board voted unanimously in favor of participating in the siting process. In June, a candidate site near the unincorporated town of Geff was identified. IDNS indicated to residents of Geff that, should the site be located there, it would help the town incorporate so that it could assume jurisdiction. By August, another site was identified in the Crisp township. Following a referendum in March 1990, indicating little support for the facility, the County Board voted 12 to 1 against hosting the facility. The Board notified IDNS that characterization of the Geff alternative site could continue, but if asked, the county would not give approval for its use as the disposal facility.

IDNS discontinued work at the Martinsville South site when it appeared that the Martinsville North site would be suitable. Because of the opposition from landowners, characterization of the Crisp site was never begun.

\subsubsection{Concerns of the Illinois Siting Commission}

In response to concern over the role of IDNS as both developer of the site and licensing agency, and interagency disputes over site characterization, the State enacted legislation in June 1990 creating a three-member Low-Level Radioactive Waste Disposal Facility Siting Commission. The law required the Commission to hold adjudicatory-style hearings to "evaluate the safety and suitability of any site proposed by the Director [of IDNS] ... by determining whether the proposed site meets all the requirements set forth in State law."

In rejecting the site, the Siting Commission maintained that there was not a preponderance of evidence showing that the site could meet four of the seven criteria in subsection (b) of the Section 12 of the Illinois Low-Level Radioactive Waste Management Act:

1. The site shall be located so that the public health, safety, and welfare shall be protected.

2. The site shall be located in a suitable geological and hydrological medium.

3. The site shall be located so as to minimize the possibility of radioactive releases into groundwater used as public water supplies.

4. The site shall be located outside the boundaries of the 100-year floodplain as determined by the Illinois Department of Transportation. 
In addition to the statutory responsibilities, the Commission also decided to evaluate the process by which the site was selected. The final report of the Commission was critical of several IDNS activities related to site selection:

- Activities of IDNS to promote the idea of hosting the facility to local governments (referred to pejoratively as "lobbying," p. 22, et seq.).

- A decision by IDNS to reduce the preferred size of the site study area from $4 \mathrm{mi}^{2}$, in order to accommodate smaller areas available in the municipality and county that expressed interest in hosting the facility (pp. 28, 38).

- A decision by IDNS to proceed with site characterization at two of four alternative sites, when it was unable to identify eight, as previously planned (pp. 26 and 28).

- Lack of documentation showing that siting officials initially considered Martinsville one of the most favorable sections of Clark County for the disposal facility (p. 33).

- A decision by IDNS to open a field office in Martinsville in order to help garner support for a site within or near that municipality (p. 36).

- That "the person who approved" the "change in (site size) criteria never was identified, and never was brought forward to justify the change" (p. 43). (It should be noted that IDNS officials involved in the siting process were not asked by the Siting Commission to provide testimony.)

\subsection{Final Site Selection}

Since revision of the Illinois Low-Level Radioactive Waste Management Act in December 1992 and again in June 1993, a Task Group has held public hearings in preparation for adopting revised siting criteria. 


\section{MAINE-UNAFFILIATED STATE}

In June 1987, Maine enacted the "Maine Low-Level Radioactive Waste Disposal Authority Act," Title 38, Chapter 14B of Maine Revised Statutes Annotated. The law established the Maine Low-Level Radioactive Waste Authority and made it responsible, "if necessary," for developing and operating a storage or disposal facility for low-level radioactive waste.

In 1993, Maine enacted legislation to enter a compact with Texas and Vermont. The compact language (that names Texas as host State for the low-level radioactive waste disposal facility) was enacted earlier in the year by Texas, and will become effective upon receiving congressional consent.

\subsection{Status}

With membership in the Texas compact region likely, Maine has suspended its site selection activities. Legislation enacted in 1993 disbands the Maine Low-Level Radioactive Waste Authority as of June 30, 1994.

\subsection{Legal and Regulatory Framework}

The Maine Low-Level Radioactive Waste Authority Act does not specify an approach or strategy for site selection and does not include site requirements.

The law authorizes the Department of Environmental Protection (DEP) to adopt site requirements through a rulemaking process. The rules were issued in September 1988. Because Maine is a NRC agreement State, the DEP regulations include technical requirements substantially equivalent to those in 10 CFR Part 61 (see Section 1.2). However, the regulations differ from the Part 61 technical requirements in several respects:

- The technical requirements that were designed by the NRC to apply to permanent disposal facilities are made applicable to facilities for "storage" of low-level radioactive waste, as well

- The requirement that the site be capable of being characterized, modeled, analyzed and monitored list several specific activities to be included in site characterization to ensure this

- The regulations require that waste disposal shall not take place in a 500-year flood plain, rather than a 100 -year flood plain

- The regulations require that the disposal site overlie surficial geologic deposits of either marine clay or basal till, or deposits that provide comparable isolation of waste

- The regulations preclude the site from containing any permeable anomalies, such as fracture zones or sand lenses 
- The regulations require that the facility provide a stable foundation for engineered containment structures and meet State regulations for soil suitability for developments.

The revised siting methodology, entitled "Maine Low-Level Radioactive Waste Disposal Facility Siting Methodology-Exclusion Criteria, Fundamental Performance and Avoidance Screening Factors," was adopted July 17, 1990.

\subsection{Siting Criteria}

The Authority's contractors, E. C. Jordan Company, Stone and Webster Engineering Corporation, and the J. W. Sewall Company, proposed a siting selection method and siting criteria. After public review and subsequent revision, the Authority formally adopted the proposal under the title, "Low-Level Radioactive Waste Disposal Facility Siting Methodology, Exclusion Criteria, Fundamental Performance and Avoidance Screening Factors," July 1990. As indicated in the title, the criteria in the report were grouped into three classifications: (a) exclusion criteria, (b) fundamental performance factors, and (c) avoidance factors. Additional "preference factors" were developed later, in consultation with the CAC:

Exclusion criteria were divided into the following seven general categories:

1. Groundwater hydrology

2. Surface water hydrology

3. Geologic hazards

4. Human-made hazards

5. Protected natural areas

6. Scenic and cultural resources

7. Land use.

"Fundamental performance factors" describe site conditions that provide natural barriers to groundwater flow and radionuclide migration. "Avoidance factors" identify technical, environmental, and land use issues that may be relatively unfavorable. "Preference factors" are relatively favorable conditions that can enhance the performance of a potential site, or reduce the impacts or costs of its construction and operation.

The report lists the criteria in matrix fashion, showing the category of each criterion and the step in the screening process at which the criterion would be applied. (Table 3 is the first page of the matrix.) 
Table 3. Screening criteria and factors.

\begin{tabular}{ccc} 
& \multicolumn{3}{c}{ Screening step } \\
\hline 1 & 2 & 3 \\
State-wide & Regional & $(1: 12,000$ or \\
$(1: 100,000)$ & $(1: 24,000)$ & $1: 7,200)$
\end{tabular}

I Exclusion criteria

A Groundwater hydrology

1. Exclude sand and gravel aquifers

Exclude primary recharge areas and water supply wells

2. Exclude areas with shallow groundwater table $(<2 \mathrm{ft})$

3. Exclude sites with anomalous zones of highly permeable soil or rock

B. Surface water hydrology

1. Exclude surface water bodies-rivers, streams, lakes, wetlands

2. Exclude coastal hazard areas and 500-year flood plains

C. Geologic hazards

1. Exclude areas with average slopes $>20 \%$

D. Manmade hazards

1. Exclude areas with facilities or activities that could adversely affect site performance or monitoring

E. Protected natural areas

1. Exclude Maine DIFW Wildlife Management areas Exclude Federal or state sanctuaries, refuges, or preserves

2. Exclude habitat of threatened and endangered species and State designated deer wintering areas

Exclude critical areas established by Maine State Planning Office, unusual natural areas, and Coastal Heritage areas

Exclude Protection Subdistricts designated by Maine LURC

Exclude lands above 2,700 ft elevation

3. Exclude the Coastal Barrier Resource System and areas of coastal sand dunes and wetlands

4. Exclude park and wilderness lands owned and administered by the Federal Government

5. Exclude park and wilderness lands owned and administered by the State of Maine including state parks, public reserved lands, and lands acquired using "Land for Maine's Future Funds"

F. Scenic and cultural resources

1. Exclude lands protected as National Wild and Scenic Rivers, or as State designated Outstanding River segments

2. Exclude historic places and archeological sites
$-$

$-$

$\mathbf{x}$

$-$

$-$

$-$

$\mathbf{X}$

$\mathbf{x}$

- $\quad-\quad x$

$\begin{array}{lll}- & - & \mathrm{x}\end{array}$

$-$

$\mathbf{x}$

$-$

$-$

$-$

-

$-$

-

$\mathbf{X}$

$\mathbf{X}$

$\mathbf{X}$

$\mathrm{X}$

X

X

$\begin{array}{lll}- & \mathbf{X}\end{array}$

X

-

X

X

$\mathrm{X}$

$\mathrm{X}$

$\mathbf{X}$

$\mathrm{x}$

$\mathrm{x}$

$\mathbf{x}$

$\mathbf{X}$

$-$

$\mathbf{X}$

$\mathbf{x}$

X

X

-

$\mathrm{x}$

-

.

$\mathrm{X}$

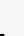

x

$x$ 
Table 3. (continued).

\section{Screening step}

\begin{tabular}{ccc} 
& Screening step \\
\hline 1 & & 3 \\
State-wide & 2 & Detailed area \\
$(1: 100,000)$ & Regional & $(1: 12,000$ or \\
& $(1: 24,000)$ & $1: 7,200)$
\end{tabular}

G. Land use

\section{-}

3. Exclude land within $1 \mathrm{mi}$ of state and international boundaries

II. Fundumental performance factors

1. Favor thick, laterally extensive soils (glacial till and marine clay) with low permeability and high retardation

2. Favor lands with a deeper water table

3. Favor lands with good conditions for surface drainage and runoff

III. Avoidance factors

A. Groundwater hydrology

1. Avoid recharge areas of sand and gravel aquifers, and bedrock wells used as community water supplies:

a. Granular soils contiguous with sand/gravel aquifers used as community water supplies

b. Watershed elements directly recharging sand/gravel aquifers or bedrock wells used as community water supplies

2. Avoid recharge areas of aquifers having significant potential for future use as public water supplies:

a. Granular soils contiguous with high yield sand/gravel aquifers (>50 gpm)

b. Watershed elements directly recharging high yield sand and gravel aquifers and bedrock localities that provide well yields $>50 \mathrm{gpm}$

3. Avoid sites with adverse hydrogeologic conditions (recharge, high gradients, and radial flow) associated with hilltops and ridgetops

B. Surface water hydrology

1. Avoid watersheds of Great Ponds

2. Avoid lands within $1,000 \mathrm{ft}$ of perennial streams and Great Ponds

3. Avoid lands within $1,000 \mathrm{ft}$ of the $+20 \mathrm{ft}$ elevation contour adjacent to the ocean shoreline

C. Surficial and bedrock geology

1. Avoid surficial deposits unlikely to provide effective barriers to groundwater movement:
a. Thin drift or bedrock
b. Stagnation moraine, end moraine, ribbed moraine

$\mathbf{X}$

$-$

$\mathbf{x}$

-

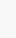

$-$

$\mathbf{X}$

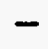

$-$

$-$

$-$

$\mathbf{X}$

$\mathbf{x}$

$\mathbf{X}$

$\mathbf{X}$

$\mathbf{X}$

$\mathbf{X}$

-

$\mathbf{X}$

$\mathbf{X}$

-

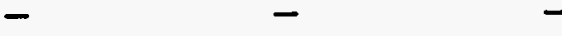

$-$

$\mathbf{x}$

$-$ $\mathbf{x}$

$\mathbf{X}$

$\mathbf{X}$

$\mathbf{X}$

$\mathbf{X}$

$\mathbf{X}$

X

$\mathbf{x}$

$\mathbf{x}$

$\mathbf{X}$

$\mathrm{X}$

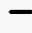

-

$\mathrm{X}$

$\mathrm{X}$

$\mathrm{X}$

$\mathbf{x}$

x

-

X

$\mathrm{X}$ 
Table 3. (continued).

\begin{tabular}{|c|c|c|c|c|c|}
\hline & & & \multicolumn{3}{|c|}{ Screening step } \\
\hline & & & $\begin{array}{c}1 \\
\text { State-wide } \\
(1: 100,000)\end{array}$ & $\begin{array}{c}2 \\
\text { Regional } \\
(1: 24,000)\end{array}$ & $\begin{array}{c}3 \\
\text { Detailed area } \\
(1: 12,000 \text { or } \\
1: 7,200)\end{array}$ \\
\hline & 2. & $\begin{array}{l}\text { Avoid bedrock structures and lithologies that may } \\
\text { provide significant pathways for groundwater flow or } \\
\text { present complex hydrologic conditions }\end{array}$ & $\mathrm{X}$ & $\mathrm{x}$ & $\mathrm{x}$ \\
\hline \multirow[t]{8}{*}{ D. } & \multicolumn{2}{|r|}{ Environmental and land use conflicts } & - & - & - \\
\hline & \multirow[t]{3}{*}{1.} & $\begin{array}{l}\text { Avoid lands in public or private ownership managed } \\
\text { entirely for conservation or recreation: }\end{array}$ & - & - & - \\
\hline & & $\begin{array}{l}\text { a. Within } 1,000 \mathrm{ft} \text { of excluded Protected Natural } \\
\text { Areas }\end{array}$ & $\mathbf{x}$ & $\mathbf{x}$ & $\mathbf{x}$ \\
\hline & & $\begin{array}{l}\text { b. Other, nonexcluded, lands managed entirely for } \\
\text { conservation or recreation }\end{array}$ & - & $\mathrm{x}$ & $\mathbf{x}$ \\
\hline & \multirow[t]{3}{*}{2.} & Avoid lands containing significant natural resources: & - & - & - \\
\hline & & $\begin{array}{l}\text { a. Presently exploited or potentially exploitable } \\
\text { mineral resources }\end{array}$ & - & $\mathrm{x}$ & $\mathbf{x}$ \\
\hline & & b. Prime farmland based on SCS soil classification & - & - & $\mathbf{x}$ \\
\hline & 3. & $\begin{array}{l}\text { Avoid locations within the direct viewshed of scenic } \\
\text { and cultural resources subject to Exclusion Factors }\end{array}$ & - & - & $\mathbf{x}$ \\
\hline
\end{tabular}

\subsection{Site Selection Process}

A salient feature of Maine's site selection process was active formal involvement of a large Citizens Advisory Group (CAG). In May 1989, the Authority organized the CAG in order to represent various interests within the State. Unlike more narrowly focussed technical advisory bodies, the CAG has a wide-ranging charter to: (a) advise and make recommendations to the Authority on management of low-level radioactive waste, (b) assist the Authority in evaluating siting policies, and (c) understand and share information with interested groups and citizens. The CAG was sanctioned as a statutory organization in response to legislation signed in late March 1992. The CAG was actively involved in the development and implementation of the Authority's siting strategy and site criteria.

With approval of the Disposal Facility Siting Methodology Report in July 1990 (see Section 5.3), the Maine Low-Level Radioactive Waste Authority adopted a two-track process for site selection. While conducting a top-down screening process, the Authority would also solicit sites from volunteer landowners. The methodology report discussed the limitations of the tools available for screening and the difficulty of merging a volunteer site process with a top-down screening:

We agree that selection of Candidate Regions should not rely on a computer algorithm. Rather, the computer GIS will be used as an aid to make the technical teams' analysis as efficient and consistent as possible... Screening is a pragmatic process to make best use of the available data to focus future efforts and resources on regions of manageable size. The process is not perfect or completely rigorous. It cannot ensure that the "best" site will be found or that some "good" sites will not be overlooked. However, we 
believe that these limitations can be compensated for, in part, by allowing future reconsideration of 'residual areas' if information indicating the possibility of a superior site should become available either during the screening analysis or through the volunteer process. All screening processes are subject to the issues and concerns expressed, precisely because their goal is to make recommendations based on data that are not complete.

\subsubsection{The Screening Process}

The screening process began in February 1989. The first phase involved application of exclusionary criteria using a GIS system. This required considerable work to digitize data not already in GIS format. A composite statewide exclusionary map was produced at a scale of 1:100,000 ( 1 in. $=$ approximately $1.6 \mathrm{mi})$. After extensive public comment, this map was adopted by the Authority in July 1991 . Figure 11 is a greatly reduced copy of the composite map.

The second phase employed a three-step approach to identify 10 candidate sites.

Step 1. The objective of Step 1 was to select candidate regions of at least $50 \mathrm{mi}^{2}$ for more detailed mapping and evaluation. In selecting the candidate regions, the Authority's contractor conducted qualitative analyses of the results of a series of map overlays representing the various performance and avoidance factors, as well as the exclusionary maps from Phase 1.

Data representing the criteria were applied statewide to develop digital overlay maps at a scale of 1:100,000. A separate overlay map was prepared for each of the State's geographical areas. Figure 12 is a statewide composite of these maps. From these maps, 12 regions that appeared to exhibit the highest percentage of exclusion- and avoidance-free land, and the largest proportion of land area satisfying statewide fundamental performance factors were recommended to the Authority. Each of the selected regions comprised approximately $200 \mathrm{mi}^{2}$, totalling about $7.5 \%$ of the State. The regions are shown in Figure 13. In December 1990, following a technical presentation by the contractor, the Authority accepted the candidate region map with slight modifications.

In selecting large regional areas for further study, the Authority designated the smaller relatively favorable areas as "residual areas," signifying an intent that they could remain available for further study during the siting process, or that volunteered sites located within the areas might be found suitable for the proposed facility.

Step 2. The objective of this step was to apply more detailed data in the 12 regions in order to allow for identification of 10 "preferred candidate areas" of 2 to $6 \mathrm{mi}^{2}$. Mapping was done at a scale of 1:24,000. Data representing exclusion criteria, fundamental performance factors, and avoidance factors were again applied at the smaller scale. The data included both mapped information and information gathered through aerial photos and field reconnaissance, such as eagle nesting areas and deer wintering habitats. The data from these observations were hand-drawn onto base maps, and then digitized for GIS application.

At this step, data representing "preference factors" that had been developed in consultation with the CAG were also applied to the maps. Because mapped data representing these 


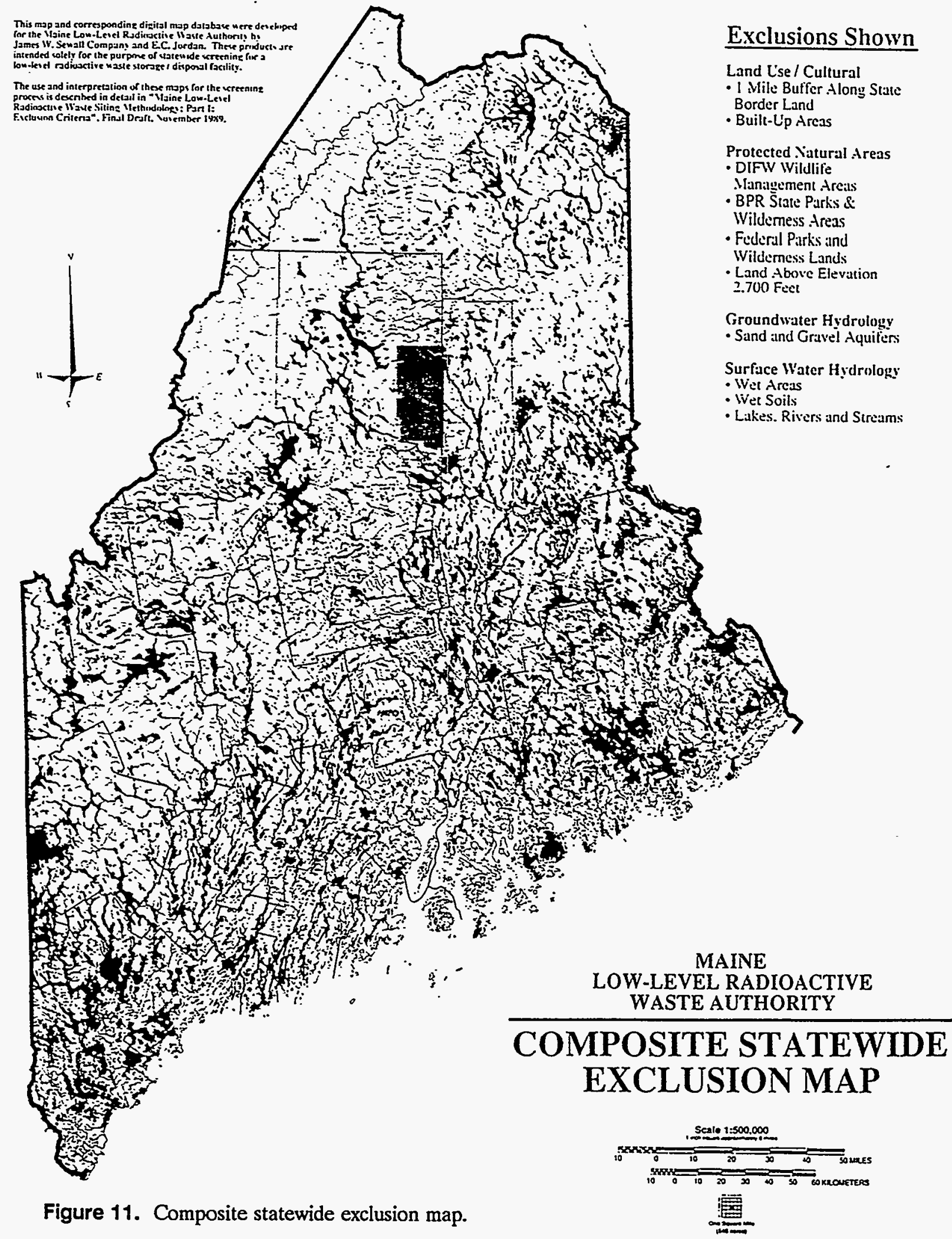




\section{Screening Criteria Shown}

This map and corresponding digital map database were deretoped for the Majne Low.Level Radiosctive Waste Authority by James W. Serall Company and EC. Jordan Company. The products are intended solely for the purpose of staterth icreening for a low-level radioncive wate storage/disposal

The use and interpretation of these maps for the screening proces is described la detzil in thine Low. Level Rodioartive Waste Disposal Facility Sitin Methodolog: Exedussar Crilesia Fundamental Periormance and A roidance Sercening Factors",
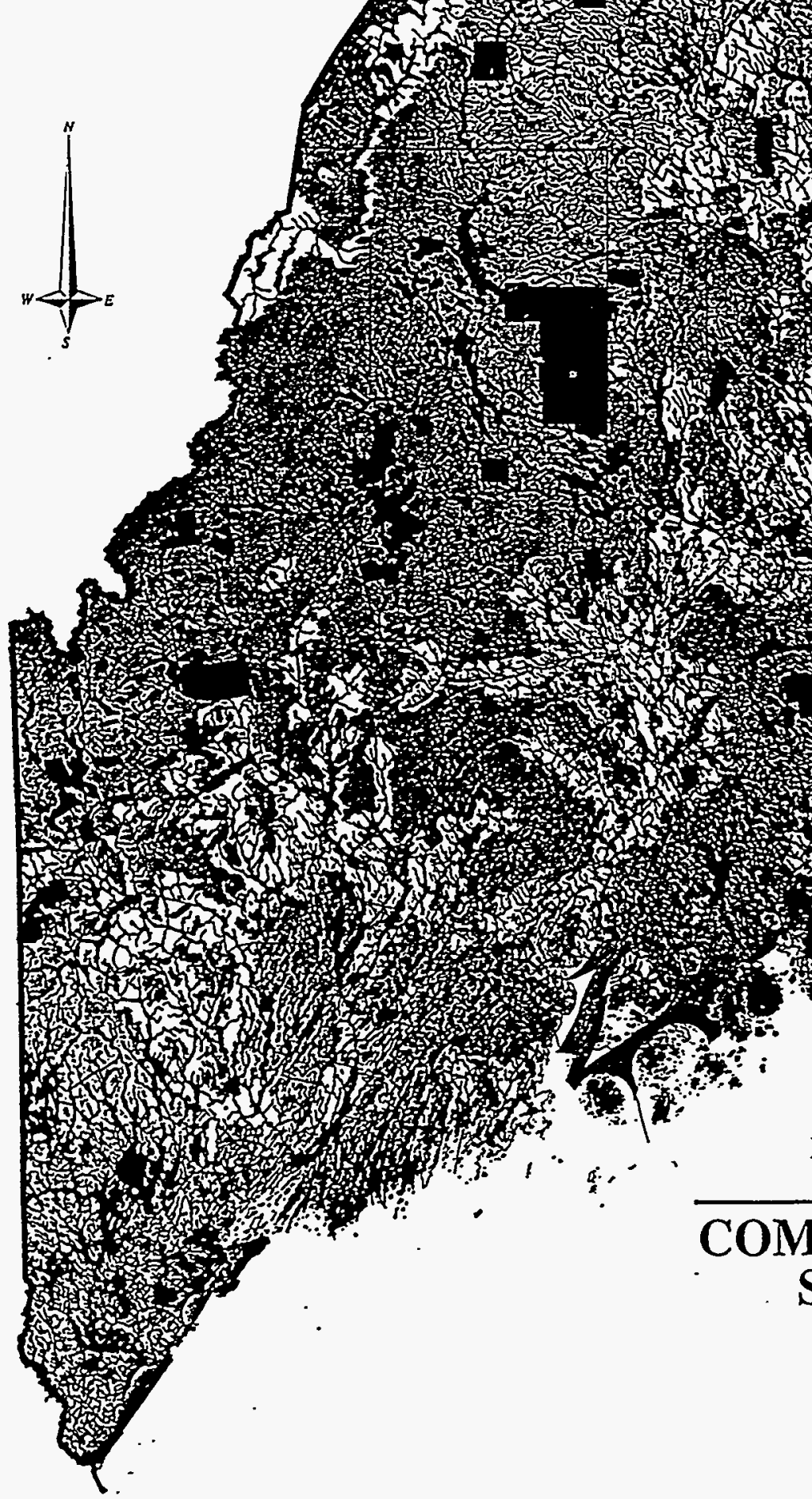

LOW-LEVEL RADIOACTIVE WASTE AUTHORITY

COMPOSITE STATEWIDE SCREENING MAP

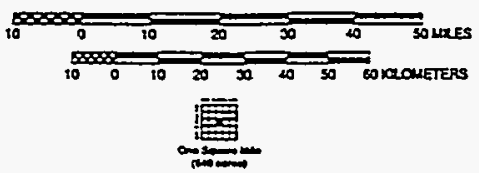

Figure 12. Composite statewide screening map. 


\section{Towns within Candidate Regions}

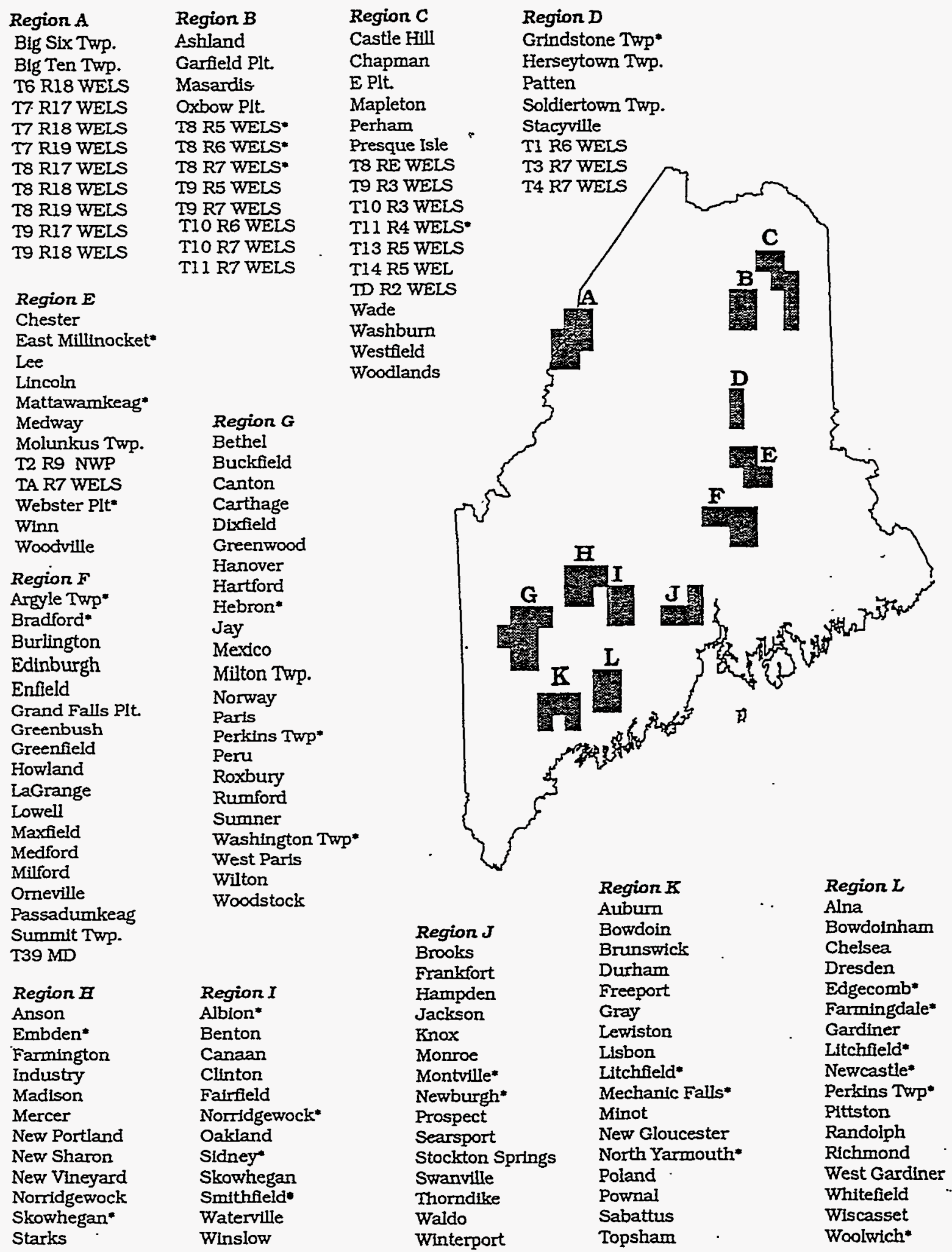

Towns followed by an contain less than 200 contiguous Exclusion and Awoidance Free acres with-in a Candidate Region and have been removed from the list.

Figure 13. Towns within candidate regions. 
conditions were not always available at this scale, only a small number of the preference factors could be considered. In winnowing the 12 regions down to preferred candidate areas, the quantitative weights given to the preference factors by the CAG were also considered by the Authority's consultants.

Step 3. The objective of this step was to identify one or more candidate sites of approximately 200 acres from each of the preferred candidate areas. New digital overlay maps at scales of $1: 12,000$ or 1:7,200 were prepared for each preferred candidate area. Where available, data for screening criteria previously applied at less detailed scales were reapplied. The information was supplemented on the maps by observations from recent aerial photographs.

As a result of this phased screening, 29 potential candidate sites, ranging in size from 374 to 5,809 acres, were identified within the preferred candidate areas. To further narrow the number of candidate sites, the Authority's contractor used a weighting/scoring method. The contractor's team evaluated each of the 29 candidate sites against each of the criteria and awarded each site a score with respect to the criterion. The relative importance or "value" of each criterion was developed in a weighting workshop involving the CAG. After calculating the summation of the weight-times-score for all of the criteria for each site, the contractor recommended that the Authority select the 10 sites with the highest numerical scores to undergo preliminary characterization studies.

During preliminary characterization, one site was dropped from further consideration. The remaining nine sites, shown in Figure 14, were as follows:

- $\quad$ Pittston Site, Kennebec County

- Edinburg Site, Penobscot County

- Summit TWP Site, Penobscot County

- T10R6 WELS West Site, Aroostook County

- Garfield Plantation South Site, Aroostook County

- T13R5 WELS South Site, Aroostook County

- T8R17 WELS Site, Northern Somerset County

- T8R18 WELS/T9R18 WELS Site, Northern Somerset County

- $\quad$ T8R19 WELS Site, Northern Somerset County.

Preliminary characterization studies were begun at each of the sites in order to identify sites to undergo full characterization as preferred candidate sites. Full characterization of the preferred candidate sites and volunteered sites was scheduled to start late in 1992. 


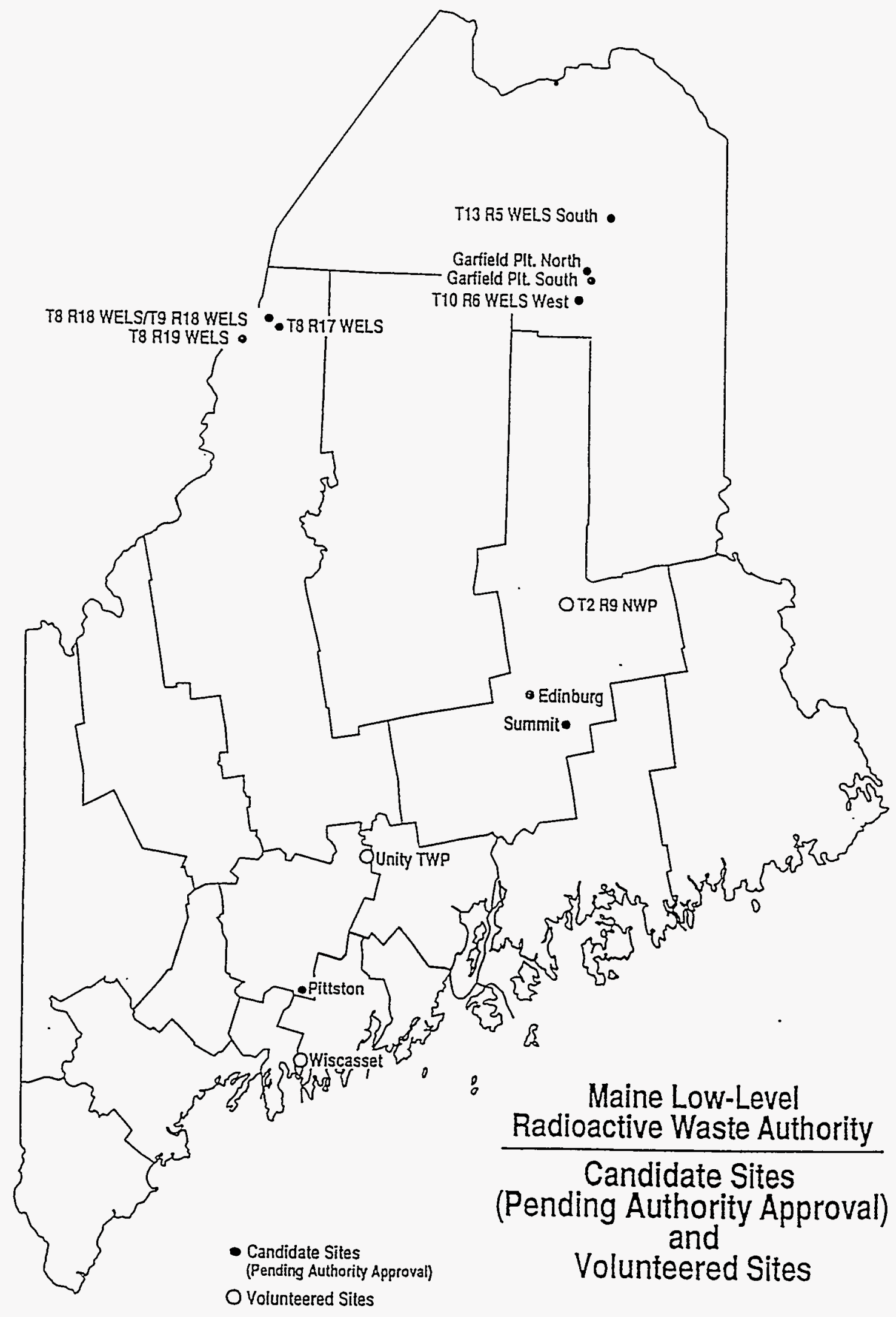

Figure 14. Candidate site (pending Authority approval) and volunteered sites. 


\subsubsection{Volunteer Process}

During the summer of 1990 , the Authority initiated a volunteer process whereby individual landowners could offer parcels to the Authority for evaluation. The solicitation effort resulted in offers of approximately 100 parcels of land, 60 of which were rejected because of obvious problems related to the site criteria.

Preliminary evaluations of the remaining 40 sites revealed unfavorable conditions on all but 12 sites. To conduct precharacterization studies, the Authority entered into agreements with nine of the landowners and discontinued evaluation of the remaining three parcels. Preliminary characterization work was performed at all nine volunteered sites. During the work, the Authority eliminated six sites as unfavorable conditions were encountered. The three volunteered sites not eliminated by preliminary characterization studies were:

- $\quad$ Maine Yankee Site, Wiscasset, Lincoln County

- Unity TWP Site, Kennebec County

- T2R9 NWP Site, Penobscot County.

\subsubsection{Demographics of the Sites}

Prior to approval of a site location, Maine law requires a $60 \%$ voter approval at the local level, a public hearing and approval by the Board of Environmental Protection, approval by the State legislature, and approval by a statewide referendum. Of the 12 sites for which preliminary characterization was completed (nine identified through screening, three offered by landowners), several numbers were in unpopulated "unorganized townships." Those located in townships with voting population were vigorously opposed by local residents.

\subsection{Final Site Selection}

Of the 12 candidate sites, four were recommended by Authority contractor Stone \& Webster for full characterization. The recommendation was made in conjunction with a technical briefing to the Authority in an open meeting. The Authority voted to accept the recommendation. Characterization work was not begun because it had become clear by that time that the State was likely to enter into a compact arrangement with the State of Texas. 


\section{MICHIGAN-MIDWEST COMPACT REGION}

At the time Michigan undertook site selection activities, it was host State for the Midwest compact region, which also consisted of Indiana, Iowa, Minnesota, Missouri, Ohio, and Wisconsin. In 1987, Michigan enacted Act 204, legislation creating the Michigan Low-Level Radioactive Waste Authority. The Authority was responsible for siting and developing the Midwest compact region's disposal facility. The Authority contracted with Michigan State University, and later with Battelle Memorial Institute, to assist in site selection. Siting criteria adopted in State law the same year were later determined to be so restrictive as to virtually guarantee that a site meeting the criteria could not be found in Michigan.

In October 1989, Michigan selected three candidate areas that were to undergo further evaluation to identify specific site locations. Prior to field work, each of the areas was eliminated under the restrictive statutory criteria.

\subsection{Status}

Michigan's membership in the Midwest compact region was revoked on July 24, 1991, and the State has discontinued siting activities. The State of Ohio, which had been named first alternate host State at the time Michigan was designated host State, was named the new host State for the compact region. The Ohio Blue Ribbon Commission and the Governor's Advisory Board on Low-Level Radioactive Waste have recommended that the State adopt a top-down screening process as the method of site selection. The balance of this report addresses Michigan's site selection process.

\subsection{Legal and Regulatory Framework}

Like most of the State laws for establishing disposal facilities, the Michigan Low-Level Radioactive Waste Authority Act provided the Authority wide discretion in designing and implementing a process by which the site would be selected. The law simply required the Authority to "select the host site." (Regarding site requirements, on the other hand, Michigan's statute was much more prescriptive than any of the other State laws. See section below.)

The law did not require that the strategy and procedures for site selection be promulgated through a formal rulemaking process. However, the law did require the Authority to adopt siting criteria through a formal process involving consultation with a statutorily created advisory panel.

\subsection{Siting Criteria}

Michigan law delegated responsibility for developing siting criteria to the Authority, but specified that such criteria exclude a site that met any of a long list of conditions. These were:

- In a 500-year floodplain

- One mile or less from a fault where tectonic movement has occurred "within the 10,000 years preceding the effective date of this act" 
- Sufficiently large to ensure that disposal units are at least $3,000 \mathrm{ft}$ from adjacent property

- Has wetlands as defined in Michigan's Geomaere-Anderson Wetland Protection Act

- An environmental area or a high risk area as defined in Michigan laws

- A floodway designated in Michigan laws

- Hydrogeology beneath the site discharges groundwater to the surface within $3,000 \mathrm{ft}$ of the boundaries of the site

- Within $10 \mathrm{mi}$ of one of the Great Lakes, and several designated rivers, except if the site is located adjacent to a nuclear power plant.

In addition to the requirements above, which applied to the siting criteria to be developed by the Authority, a separate section of the law lists several other site requirements of an exclusionary nature. These included:

- Groundwater travel time along any 100 -ft flow path from the edge of the disposal unit is greater than approximately 100 years

- "Six or more meters of soil with a maximum permeability of 1.0 times 10 to the minus $6 \mathrm{~cm} / \mathrm{sec}$ at all points below and lateral to the bottommost portions of the leak detection system of the disposal unit," or an area that provides equivalent protection

- Not above an aquifer that is the primary source of water for a municipality or county "or for persons doing business in the municipality or county."

The law also required the Authority to give "preference" to sites with a number of other characteristics, several of which are identical to site requirements in Federal regulations, $10 \mathrm{CFR}$ Part 61. However, the law provided that the Authority may waive one or more of these preference factors following a process involving public hearings. (In practice, the Federal requirements cannot be waived by State actions.).

In July 1990, a report prepared by Linda Lehman and Associates for the Midwest Compact Commission concluded that, "... it is highly unlikely that any suitable site will be found in Michigan. The very restrictive nature of the criteria themselves and the method of application by the Authority virtually guarantee that no site will be found."

The Authority entered a contract with the Department of Resource Development at Michigan State University to conduct a statewide exclusionary screening. Based on the requirements in the law, the Michigan State team developed 33 specific siting criteria in consultation with a Siting Criteria Advisory Committee, a panel consisting of members of the State's scientific community appointed by the Authority. In addition to the requirements in the statute and criteria derived from those requirements, the criteria included other technical and land 
use considerations. One criterion required that, if all other criteria are met, preference should be given to areas near communities desiring the facility.

\subsection{Site Selection Process}

\subsubsection{Selection of Siting Strategy}

It was not possible to determine within the scope of this report just when the Michigan Authority decided to employ a phased top-down process as the strategy for site selection. Prior to enactment of Act 204, negative public reaction at hearings held by the State's "Radioactive Waste Control Committee" contributed to a view among Authority staff that a volunteer approach would probably not be successful.

A 1989 report prepared for the Authority by consultants at Michigan State University states:

The State of Michigan is required to initiate a site selection process which would identify a suitable location for (the disposal facility). This requires, as a first step, the design and implementation of screening procedures ... Such a screening process must be carried out in full compliance with the requirements of the Federal Low-Level Radioactive Waste Policy Act of 1987 (sic) and other applicable Federal and State statutes. Under auspices of a research grant to the Department of Resource Development, Michigan State University faculty and staff were asked to assist in the design and implementation of a screening method with guidance of Michigan's Radioactive Waste Authority and the appointed Site Screening Advisory Committee ...

The statement suggests that Michigan planners believed that Federal laws or regulations required the use of a phased, top-down screening process. (Although the Low-Level Radioactive Waste Policy Amendments Act of 1985 required States to "screen for broad siting areas," the Department of Energy had decided in late 1987 that siting plans involving voluntary screening phases were consistent with the law. Similarly, Federal regulations of the NRC do not constrain States in the methods by which sites are selected, as long as the sites meet the requirements.)

\subsubsection{Statewide Exclusionary Screening}

For statewide exclusionary screening, Michigan State University first applied exclusionary criteria to $1-\mathrm{km}^{2}\left(0.39-\mathrm{mi}^{2}\right)$ grids using a GIS system. A number of data sets needed for the screening required conversion to digitized format. Data representing or approximating the following factors were applied:

- Certain rural and urban places

- Mercalli (seismic) intensity

- Certain hydrologic features

- Forested and nonforested wetlands 
- Thickness of glacial drift

- Selected Quaternary geologic features

- Selected soil associations based on permeability and drainage

- Aquifer vulnerability

- Great Lakes shoreline

- Well locations for public water supplies

- Federally designated lands.

Following application of the exclusionary criteria in these areas, remaining areas too small to accommodate the proposed site were also eliminated. The statutory screening requirement that the disposal units be located at least $3,000 \mathrm{ft}$ from adjacent property dictated that the size of the site be nearly $2 \mathrm{mi}^{2}$. This eliminated all clusters consisting of fewer than nine $1-\mathrm{km}$ grids, and many irregularly shaped clusters that otherwise would not have been eliminated using the factors noted above. The requirement effectively cleaned the map of the many small "pinpoint" areas, symptomatic of the intermediate results in Connecticut (see Figure 8).

The statewide screening eliminated over $97.3 \%$ of the State from consideration-far more than first-step exclusionary screenings in any other State. This result is attributed to a number of factors. A recent report for the Michigan Authority by Battelle Memorial Institute evaluates the impact of various criteria and decisions on the siting process. The report, An Evaluation of the Michigan Siting Criteria and Their Effect on the Elimination of Land Area for Siting a Low-Level Radioactive Waste Isolation Facility (November 1993) (referred to as the Battelle Report) cites several factors leading to elimination of much of the State. These include:

- The Siting Criteria Advisory Committee and the Midwest Compact Commission believed that some of the criteria in the statute had no defensible scientific basis

- Expansion of the minimum size for the site from 1,200 acres specified in the law to 2,250 acres. This site size was dictated by the GIS system, which used square-kilometer grids. Grids measuring $2-\mathrm{km}$ on a side would have provided only 988 acres. Therefore,

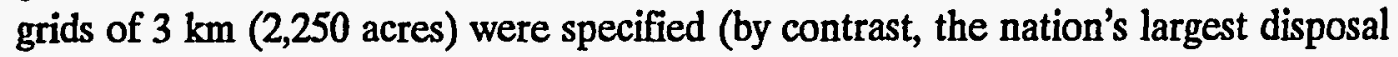
facility for low-level radioactive waste in Barnwell County, South Carolina, is approximately 300 acres).

- It was decided to employ surrogate data to represent criteria in a number of cases where more direct measurements were unavailable. For example, excluding areas identified as marsh or wetlands, or soil associations dominated by the presence of organic soils intermixed with (wet) loamy or wet sandy soils, as a substitute for areas where the water table is not sufficiently low to prevent the intrusion of groundwater into the bottommost portions of the leak detection system. 
Following the exclusionary mapping exercise, a key administrative decision was made by the Authority to defer from consideration all but the largest three contiguous areas from the 79 that resulted from the process. This further reduced the amount of land under consideration in the next step from $2.7 \%$ of the State to $0.1 \%$, or 49,000 acres. The areas were located in Lenawee, Ontonagon, and St. Clair Counties. Officials and residents of the counties vigorously objected to the idea of having the site within their borders.

\subsubsection{Area-Level Evaluation}

Using a more complete database for wetlands, the entire study areas in Ontonagon and St. Clair Counties were eliminated from further consideration in early 1990.

The Battelle Report indicates that application of a nonstatutory criteria, proximity to humanmade features, was responsible for elimination of some 6,450 acres of 14,600 in the Lenawee County study area. The criteria had been intended to be used as an evaluation criteria with which to compare sites "in the event several otherwise potentially favorable sites can be identified." The human-made features to be avoided included various pipelines, wells, railroads, and roadways. Using measures of proximity to the various human-made features, the criterion was used instead as an exclusionary criterion to eliminate land within the study area from further consideration. The land in Lenawee County remaining after application of the criterion was also eliminated due to wetlands, groundwater discharge to the surface within $3,000 \mathrm{ft}$ of the disposal unit, and flood prone areas.

\subsubsection{Reexamination of the Deferred Areas}

With elimination of the three largest candidate areas, the Authority decided to reexamine the 76 areas that had been deferred, using readily available data for the more stringent State criteria. The study was suspended in 1991 following revocation of Michigan's membership in the compact region. The Authority contracted with Battelle in 1993 to complete the study. The report, issued in November 1993, concludes that:

- While it is impossible to demonstrate absolutely that the siting criteria cannot be met without carefully examining the entire State, the results of the siting process, and this study indicate that it is highly unlikely that an area can be found that will meet all of the siting criteria.

- Limitations on available data, along with time frames required in State and Federal law, forced the Authority to make certain administrative decisions regarding the use of data and the conduct of the siting process. Because of the restrictive nature of the criteria, however, the administrative decisions made by the Authority regarding application of the siting criteria ultimately had little impact on the availability of candidate sites.

\subsection{Final Site Selection}

A site has not been selected in Michigan and siting activities have been suspended. 


\section{NEBRASKA-CENTRAL COMPACT REGION}

The Central compact region eonsists of Arkansas, Kansas, Louisiana, Nebraska, and Oklahoma. The terms of the Central compact call upon the Compact Commission to promote the establishment of regional low-level radioactive waste management facilities by selecting bids from companies in the private sector to develop such facilitics. The Compact Commission selected US Ecology. Inc., to sitc, develop, and operate the regional disposal facility.

As originally envisaged when the compact was being negotiated, the siting process was to be regional in nature. That is, the terms of the compact do not specify that a host State for the facility be designaled as part of the process leading to selection of a site location. However, because the Low-Level Radioactive Waste Policy Amendments Act of 1985 required compact regions 10 either identily a specilic sitc. or name a host Statc by January 1. 1988. the Compact Commission decided lo designale a hosit Stalc. Nehraska was named hosi State by the Compact Commission in late 1987, based on a recommendation by its site operator-designce.

\subsection{Status}

As the disposal site developer for the compact region. US Ecology began the site selection process in 1988 and narrowed the selection to three candidate sites in carly 1989. Sitc charactcrization of candidate sites in Boyd. Nuckolls. and Nemaha Countics began in March of the same year. Additional detailed sitc characterization to support the license application continued. On December .31. 1989, at the conclusion of a year of characterization activities. L'S Ecology selected a location in Boyd County near the village of Butte as the preferred site. A licensc application was submitted in July 1990.

Development of the site has been affected by two issues. The first involves whether or not US Ecology complied with a Nebraski law requiring the developer to "make every' effort" to locate the facility where "community support is evident" (sec Section 7.3). The second issue was related to review of the license application. On January 22, 1993. the Nebraska Department of Environmental Quality and the Department of Health issued a joint public Notice of Intent (o) Jeny the license application. citing adverse surface water characteristics and proximity of wedlands. On October 4. 1993, the Department of Environmental Quality (DEQ) withdrew the notice. after US Ecology redrew the boundaries of the formal site area to exclude the wetlands. The change resulted in minor relocations of the disposal units and surface water retention pond.

\subsection{Legal and Regulatory Framework}

Alhough the license-designec, US Ecology, is under contract to the Compact Commission, the Nebraska Low-Leval Radioactive Waste Disposal Act (Ncb. Rev. Stat. 81-1578, Cum. Supp. 1988 ) impeses some requirements directly upon the contractor that are not related to the State's responsibilities under the NRC Agrecment State Program to license and regulate the facility. In addition, the law gives the State's DEQ authority to impose other requirements. For example. during the siting presess, the DEQ can require the site developer to submit "plans, specifications. and other data for siting, construction, and operation" of the disposal facility. 
As a NRC agreement State, Federal site suitability requirements and performance objectives are reflected in State regulations of the Department of Environmental Quality. These are in Title 194, "Rules and Regulations for Disposal of Low-Level Radioactive Waste."

\subsection{Siting Criteria}

Although not a siting requirement in the legal sense, the former governor of Nebraska issued conditions under which she would continue to support the development of the regional disposal facility in the State. One condition pertaining to siting required that assurances be given that "US Ecology and the Compact Commission will not locate a facility in a community without community consent. Nebraska's 1988 enabling legislation includes a variation on the idea of community consent in the "legislative policy" section of the law:

It is the intent of the Legislature that potential host communities be actively and voluntarily involved in the siting process. To the extent possible, consistent with the highest level of protection for the health and safery of the citizens of the state and protection of the environment, the developer shall make every effort to locate the facility where community support is evident $(81-1579,1988)$.

US Ecology developed screening criteria based on the following guidance and directives:

- Site suitability requirements from 10 CFR Part 61.50, as reflected in Nebraska's regulations

- The governor's stipulation regarding community consent

- Various Federal and State regulations on environmental quality and land use

- Siting constraints related to engineering requirements for the design, construction, operation. monitoring, and long-term stability of the facility after closure.

As indicated in Table 4, general criteria statements were developed for eight screening factors, with more specific statements developed appropriate to the level(s) at which the factor would be applied in screening.

Beneath each of the screening factors, more specific criteria statements were developed to describe application of the criteria at the State, regional, and/or county levels. For example, the general criterion for "land use," noted that "dedicated lands, protected or restricted by Federal, State, or local law for specific purposes are not suitable." Under State, regional, and county level, the specific criterion was, "Include geographic areas for further study that are located outside the boundaries of existing and formally proposed Federal and State protected or restricted lands." The criterion was applied at all three levels in order to add precision to these boundaries at progressively smaller scalcs. 
Table 4. General criteria statements.

\begin{tabular}{lccc}
\hline & \multicolumn{3}{c}{ Level of application } \\
\cline { 2 - 4 } \multicolumn{1}{c}{ Screening factor } & Statewide & Regional & County \\
\hline Ground water & - & - & $\mathbf{x}$ \\
Geology & - & $\mathbf{x}$ & $\mathbf{x}$ \\
Surface water & $\mathbf{x}$ & - & $\mathbf{x}$ \\
Land use & $\mathbf{x}$ & $\mathbf{x}$ & $\mathbf{x}$ \\
Population and urban growth & $\mathbf{x}$ & - & $\mathbf{x}$ \\
Cultural resources & - & - & $\mathbf{x}$ \\
Biological resources & - & - & $\mathbf{x}$ \\
Community compatibility (consent) & - & $\mathbf{x}$ & - \\
\hline
\end{tabular}

\subsection{Site Selection Process}

The objective of the screening process was to select three candidate sites to undergo complete characterization, in accordance with Nebraska's law. The screening process was comprised of the following steps:

- $\quad$ Statewide screening

- Regional screening

- County-level screening (resulting in "potential areas")

- Evaluation of potential areas (resulting in "potential siting areas")

- Selection of three candidate sites.

\subsubsection{Statewide Screening}

Site screening began with the application of State-level screening criteria using a USGS base map of Nebraska at a 1:500,000 scale. The following land was excluded:

- Existing and formally proposed Federal and State protected or restricted lands

- Land within $15 \mathrm{mi}$ of communities with a population of at least 100,000

- $\quad$ Land within $2 \mathrm{mi}$ of communities with a population of at least 5,000

- Land located within the 100-year flood plain of major rivers. 
US Ecology plotted the data on map overlays to develop a composite map. The statewide screening eliminated only a very small percentage of the State from further consideration.

\subsubsection{Regional Screening/Community Consent}

Regional screening criteria were then applied using overlays at a scale of $1: 250,000$ to the areas not previously excluded. Criteria applied during the regional screening were from the geology, land use, and community compatibility criteria groups.

The community compatibility criterion was last applied during the regional screening. It required a "formal invitation by host entity to evaluate their area." In order to elicit interest, US Ecology in June 1988 sent an information package to various community and county organizations describing the proposed facility and outlining potential benefits. The package asked the organizations to provide a formal response expressing interest in having the area evaluated for the proposed facility. Twenty counties and 72 communities expressed interest.

Because the 72 interested communities were not necessarily located within the 20 interested counties, US Ecology asked its CAC how best to apply the community compatibility criterion. The CAC advised that a county unit should be considered an "interested entity" and that interested communities should work with their county boards to obtain statements of interest. Area within the 20 counties that had not been eliminated because of other statewide and regional criteria represented $22 \%$ of the State. Figure 15 is a composite map of criteria overlays showing areas excluded, and those that remained after State and regional-level screening. In the illustration, the close relationship of the "areas for further consideration" with county boundary lines suggests that, although the site selection process to this stage was ostensibly a phased, topdown process, similar results would have resulted from an overtly "volunteer" process.

\subsubsection{County-Level Screening}

During county-level screening, 16 county-level criteria were considered, some of which were reapplications of criteria applied in the earlier steps using data at a smaller scale. Like statewide screening, the county-level screening was exclusionary in nature. County highway maps at a scale of $1 / 2$ in. = 1 mi were used as base maps. Screening was accomplished manually by transposing information from source maps and other data sources onto the base maps. (Original overlays and map work sheets from the exercise are retained in US Ecology's project files.) At this stage, locally available data were used where available. Screening at this level in this manner was essentially an "analog" process, which did not necessitate the use of standard-sized square grids. Because the screening was exclusionary in nature, it did not lend itself to the kind of weighting and scoring exercises that had been conducted in several other States.

During the county-level screening, three counties withdrew their expressions of interest and were removed from consideration. Following the screening, 81 potentially suitable areas in 17 counties were identified. The areas comprised approximately $2,900 \mathrm{mi}^{2}$, or $4 \%$ of the State, and about $17 \%$ of the participating counties. Maps were prepared showing the potential areas within each county. Six more counties withdrew their expressions of interest after the potential areas were identified, leaving 111 potential siting areas (PSAs) in 11 counties for the next phase of screening. The PSAs ranged in size from 0.5 to $18 \mathrm{mi}^{2}$. Figures 16 and 17 show PSAs in Boyd 


\section{Results of State and Regional Screening}

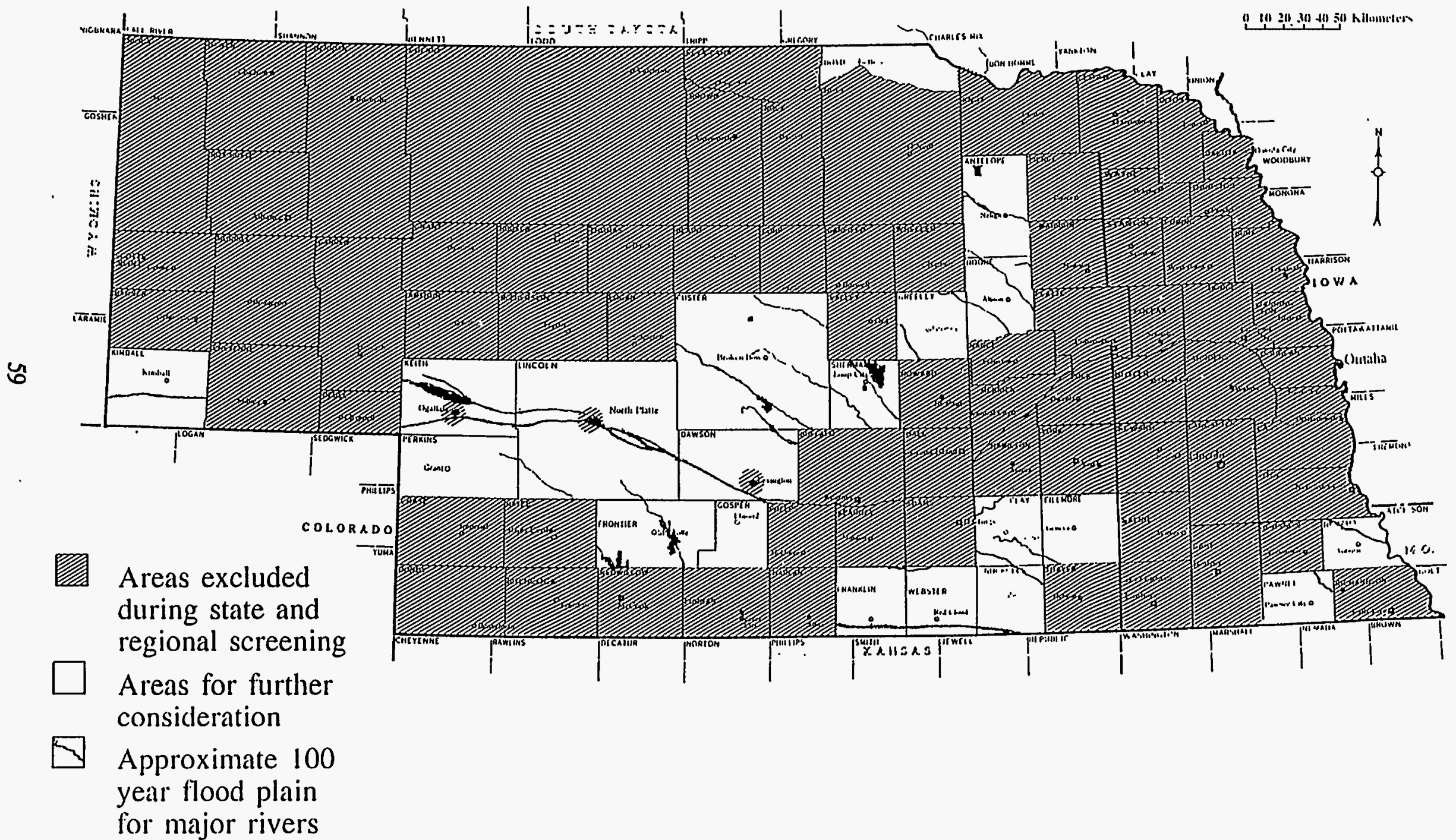

Figure 15. Results of State and regional screening. 
Map of Boyd County, Nebraska

Showing the Potential Siting Areas Within the Potential Areas Octolocr 31, 1988

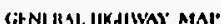

BOYD COUNTY

NEBHRASKA

DEPARIMENT OF ROAOS

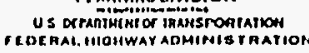

$m+m+\frac{1901}{2}$

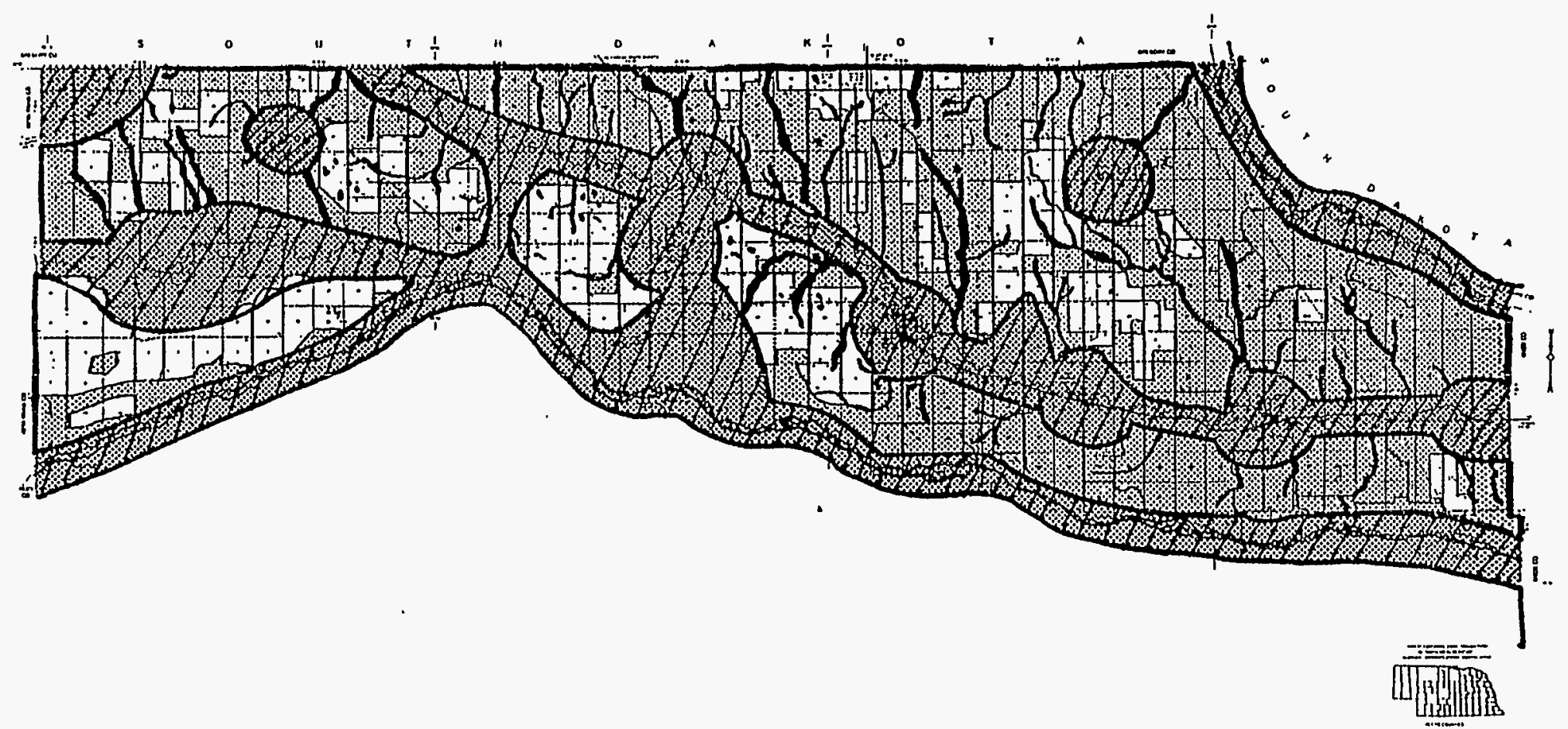

\section{EXILANATION}

$\square$ Polential Siting Arcas

[: Polcmial Areas (Outside Polential Siling Areas)

Outside Potential Areas

$\triangle$ Flood Plains

Figure 16. Map of Boyd County, Nebraska. 
Map of Nemaha County, Neloraska

Showing the Potenlial Siting Areas Within the Potential Areas Octolser 31, 1988
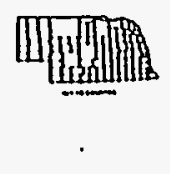

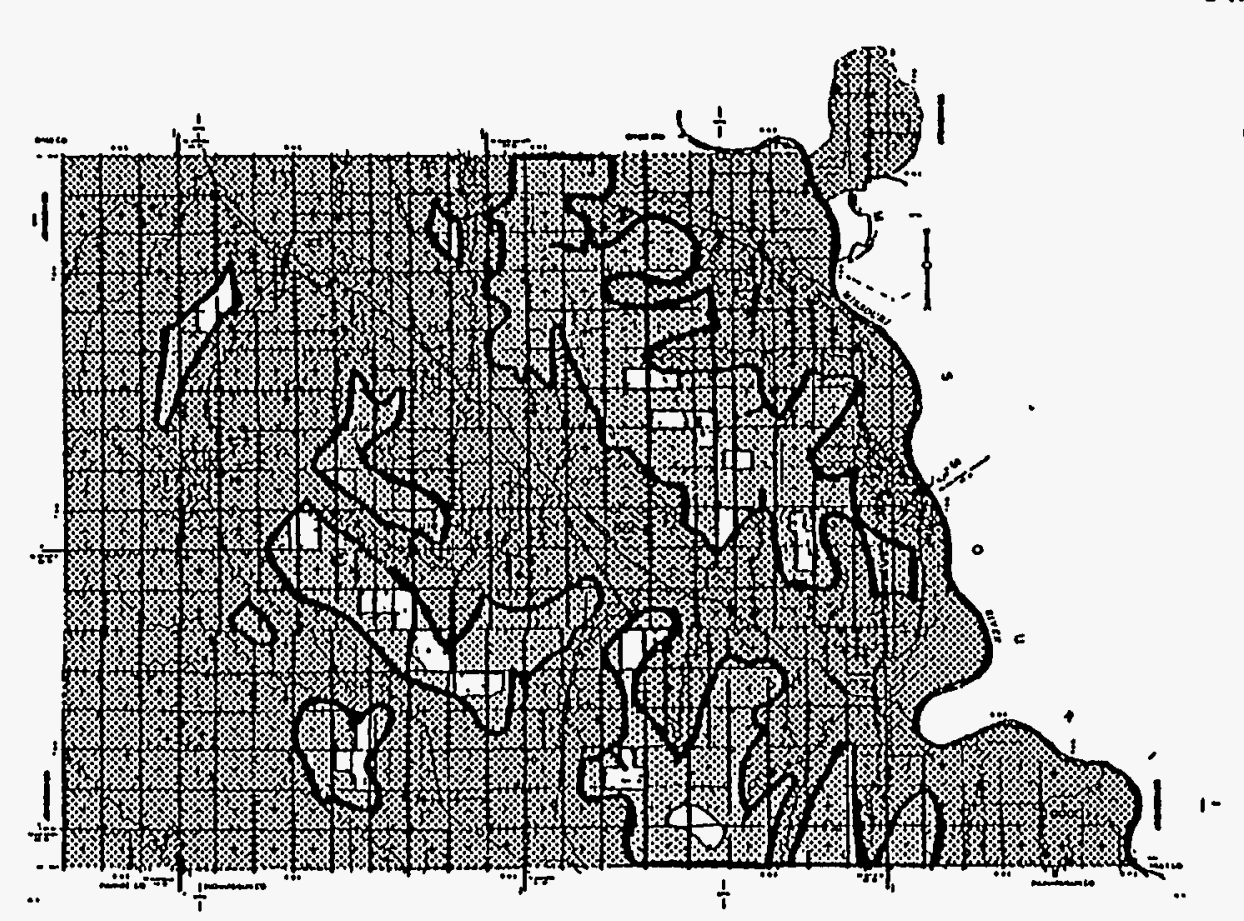

Malwar ment

NEMAHA COUNIY

NEBIRASKA

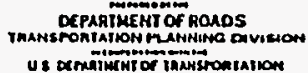

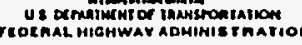

1903

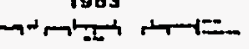

\section{EXPI.ANATION}

$\square$ Polcutial Silling Arcas

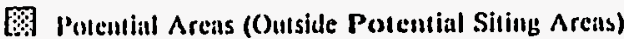

\%ollside Polential Arcas

$\triangle$ Plowd Plains

Figure 17. Map of Nemaha County, Nebraska. 
and Nemaha Counties. The results of the county-level screening were presented to the CAC in October 1988.

\subsubsection{Selection of Preferred Regions}

The 111 potential siting areas were distributed among five geologic regions of the State. US Ecology categorized each the 111 PSAs as having a high, moderate, or low probability for licensing. The categorization was based largely on the amount and quality of existing data related to geology and groundwater considerations. The final categorization was adjusted to take into account significant surface water and environmental considerations.

With support from the CAC, US Ecology decided that it would be preferable to select the three sites for characterization from different geographic regions in order to increase the probability that at least one site would prove suitable for the facility following characterization. To select the three regions from the five that had PSAs, US Ecology selected 27 representative PSAs with a high or moderate probability for licensing from the five regions. In a structured exercise conducted in November 1988, the CAC ranked each of the five regions based on an intercomparison of the representative PSAs against criteria that the CAC believed to be most significant. In general, the representative PSAs in the three selected regions exhibited greater diversity in depth to water and to bedrock, and soil features, suggesting a higher likelihood that superior sites might be located in these regions.

\subsubsection{Selection of Candidate Sites}

The next step was selection of three sites to undergo full characterization. Site selection was accomplished through an iterative process involving reexamination of the criteria with data available at the local level, area reconnaissance and site walkovers, and solicitation of landowners interested in selling tracts of land. For example, where technical judgment suggested that a land area might be especially suitable, intensified efforts were made to solicit landowners; where landowners with large tracts came forth, efforts were intensified to evaluate the likelihood of the land to ultimately meet licensing requirements.

Recognizing that locally available data could alter assessments of PSAs, US Ecology continued to refine, add, and delete PSAs throughout the site selection process. A finalist site in Nuckolls County, for example, was located on a PSA that was added following regional selection in response to data from the archives of the Nebraska Geological Survey indicating up to $250 \mathrm{ft}$ of silt and clay overlying bedrock. Data used earlier in the process had suggested a thinner layer consisting mostly of sand and gravel. Ultimately, the three finalist sites were those that remained after each of the others was downgraded based on technical, site access, or site acquisition considerations. The sites were located in Boyd, Nemaha, and Nuckolls Counties.

\subsection{Final Site Selection}

Following characterization of the sites, US Ecology, on December 31, 1989, selected the Boyd County (Butte) location as the preferred site. Characterization activities continued at the other two sites, however, to provide complete documentation of the rational for the selection. A 
license application for a disposal facility for the Butte site is currently under review by the Nebraska Department of Environmental Quality and the Department of Health.

General Accounting Office Study. In July 1991, at the request of Senator James Exon of Nebraska, the General Accounting Office (GAO) performed a study on the selection and characterization of the Butte site. The GAO concluded that the selection process had been performed correctly and agreed that the Butte site was the strongest of the three sites. In addition, the GAO found that, because of the geologic characteristics of the other two candidate sites considered by US Ecology, there is no technically strong substitute site available if Nebraska denies the license application of the Butte site. 


\section{NEW YORK-UNAFFILIATED STATE}

New York participated in early compact discussions of the Coalition of Northeast Governors, but decided not to enter the proposed Northeast compact. On July 26, 1986, the State enacted the Low-Level Radioactive Waste Management Act. The law declared New York's intention to develop a disposal site for low-level radioactive waste, and divided responsibilities for establishing the new facility among several State agencies:

- The New York Low-Level Radioactive Waste Siting Commission (Siting Commission) was established to site the facility and propose a disposal method.

- The Advisory Committee on Permanent Disposal Facilities, Siting and Disposal Method Selection was established within the Siting Commission and given a formal advisory role.

- The New York Department of Labor is the NRC Agreement State agency responsible for issuing the radioactive materials license.

- The New York Department of Environmental Conservation was given responsibility to develop regulations for siting, construction, operation, and closure of the facility and for the method of disposal, and to certify that the site location and recommended disposal method meet the regulatory requirements. DEC is also responsible for issuing an environmental permit for construction and operation of the facility.

- The New York State Energy Research and Development Authority (NYSERDA) was given responsibility to construct and operate the disposal facility, and to administer generator fees for the establishment of the facility.

- The New York Department of Health was made responsible for conducting a public information and education program on low-level radioactive waste management.

\subsection{Status}

The Siting Commission performed a statewide site screening in 1988 and 1989 resulting in identification of five sites as possible locations for the disposal facility, two in Cortland County and three in Allegany County. In late 1989 and early 1990, the Commission and its contractors attempted to conduct preliminary activities at the sites, but were physically prevented by opponents of the siting process. This led the governor of New York to recommend suspension of further onsite work pending a review of the siting process. After completion of the evaluation, the State Low-Level Radioactive Waste Management Act was amended to address public concerns and perceptions, the most significant of which was the legal requirement that the Siting Commission select a preferred method of disposal before selecting the candidate site.

The Siting Commission is currently implementing a plan for selecting the method of disposal, as required in the 1990 amendment. The plan includes siting criteria specific to disposal methods that may be chosen. The disposal method selected and approved may have an effect on the 
suitability of the potential sites that were selected previously and on the need for further site selection activities. In 1993, the Commission passed a resolution declaring that the five sites identified through the siting process would no longer be considered "preferred sites." The Commission directed its staff to develop a process for soliciting volunteer communities to host the disposal facility.

\subsection{Legal and Regulatory Framework}

New York's Low-Level Radioactive Waste Management Act of 1986 did not mandate specific siting criteria. However, the law did require the Department of Environmental Conservation to develop through a rulemaking process "the minimum characteristics a disposal site and a disposal method must have under existing Federal and State law to be acceptable for use for permanent disposal facilities." The law required that such regulations be specific to the types of disposal methods that may be employed at a permanent disposal site, and shall include criteria for:

- Aboveground, monitored, retrievable disposal

- Underground, mined, repository disposal

- Where practicable, other disposal methods for which there are applicable regulations : but in no event including shallow land burial.

The law contains a moderate amount of detail on the process for developing siting criteria and certifying that the site or sites meet the criteria, but does not address the specific process by which the Siting Commission should identify candidate sites for characterization. Nor do the regulations of the DEC limit the discretion of the Siting Commission by prescribing a specific process for selecting disposal sites. While the law and regulations leave the decision on a siting strategy with the Siting Commission, they do limit the Commission in one regard. They explicitly exclude the Western New York Nuclear Service Center (known as "West Valley") from consideration as a potential site. Ironically, a site in the West Valley area is considered by many to have the greatest potential for community support.

The law also required the Siting Commission to propose a disposal "method" or technology to DEC at the same time that the site location was proposed. Because DEC issued regulations on the site and disposal method requirements in 1987, prior to implementation by the Commission of its processes, the regulations included three sets of site requirements, including (a) those applicable to all sites regardless of the disposal method, (b) additional requirements for sites employing aboveground and belowground near-surface disposal methods, and (c) additional requirements for sites using mined methods. This unusual lack of sequencing made it necessary for the Siting Commission to perform parallel siting processes for the conventional aboveground/belowground disposal methods and for mined methods, with both processes converging in the end in a set that included sites suitable for both technologies. 


\subsection{Siting Criterla}

Regulations issued by DEC in December 1987 divided siting critcria into three categories. The first category, Part 382.21, included siting criteria applicable to all disposal methods. The second category, Part 382.22, included additional critcria for aboveground and belowground disposal methods. The third category, Part 382.23, included additional siting criteria for underground mined repositories.

Based on the DEC regulations, the Siting Commission and its technical contractor, Roy F. Weston, Inc., developed a set of 61 "criteria statements," including both exclusionary statements and preference statements. In matrix fashion, each of the 61 statements was labeled as applying to aboveground/belowground facilities and/or mined facilities. In addition, the matrix illustrated the step in the siting process where each criterion could be applied-during the statewide exclusionary screening, during the candidate area identification, and/or during the potential site identification step. The 61 criteria statements were organized into 13 "siting factors" representing the usual categories of site characteristics:

- Geology

- Natural resources

- Groundwater hydrology

- Surface water hydrology

- Meteorology

- Air quality

- Ecology

- Incompatible nearby activities

- Demographic patterns

- Land use

- Cultural resources and aesthetics

- Transportation

- Socioeconomics and community services. 


\subsection{Site Selection Process}

The decision to employ a phased, top-down screening process was formally made as part of the request for proposals for technical support services in site selection. In response, each of the proposals submitted in early 1988 featured this approach to site selection.

Site selection consisted of two phases. Phase I involved top-down mapping and limited onsite observations to identify approximately four potentially suitable candidate sites. Phase II is characterization of each of the potentially suitable sites and recommendation of a single site to DEC for certification.

Under the Siting Commission's siting plan, "if a unit of government or another party requests consideration of a particular area or parcel of land, it will be evaluated and compared with other areas or sites resulting from screening." Under the guideline, such requests could come from communities that express interest in hosting a site, individual property owners offering a particular site, or third parties that suggest a particular location. In its siting plan, the Siting Commission adopted a policy that any such volunteered site that had community support would be compared with other potentially suitable sites unless it was eliminated from consideration by exclusionary criteria. In January 1989, the Commission amended the policy to distinguish between a "volunteer site," which has support in the local community, and an "offered site," a parcel offered by its owner without local support. For an offered site to be considered, it had to meet the cutoff score established for the siting step at which it was brought to the Commission's attention. The amended policy required that such sites be at least as good as the sites being considered at that stage.

A four-step process was used by the Siting Commission and Weston to screen the State for candidate sites. These steps include:

1. Statewide exclusionary screening (same exclusionary criteria for aboveground and belowground methods, new mines, and existing mines).

2. (a) Statewide exclusionary screening using additional criteria, (b) application of statewide preference criteria to produce composite favorability maps for aboveground and belowground methods, new mines, and existing mines, and (c) further comparative assessments to select 10 candidate areas.

3. Small-scale screening of the $\mathbf{1 0}$ candidate areas to identify specific sites.

4. Limited onsite studies to select approximately four for detailed characterization.

Step 1. Statewide exclusionary screening. In the first step, statewide exclusionary screening was performed using criteria-related data gathered and entered into the GIS. Five exclusionary criteria were applied during this stage, involving groundwater hydrology, demography, and land use. Application of the criteria eliminated approximately $30 \%$ of the State's land area. Because the exclusionary criteria were relevant to the range of disposal methods under 
consideration, a single exclusionary screening base map was prepared. Figure 18 shows the areas excluded at the conclusion of Step 1 screening.

Step 2. Identification of candidate areas. This step involved three substeps: (a) application of additional exclusionary criteria, (b) application of preference criteria, and (c) comparative assessments of potentially suitable areas.

\subsubsection{Additional Exclusionary Criteria}

At the beginning of Step 2, additional exclusionary criteria were applied. These were exclusionary criteria that required "some qualification or interpretation of regulatory requirements" and "other criteria that address conditions that may not have strict legal or regulatory definitions of the boundaries." The criteria included:

- High-yield aquifers (additional to those considered in Step 1)

- Surface water bodies

- Pollution nonattainment areas

- Federally and State protected land (additional to those considered in Step 1)

- The Western New York Nuclear Service Center in West Valley.

Application of these additional exclusionary criteria eliminated only an additional $10 \%$ of the State, leaving $60 \%$ of the State still potentially eligible (see Figure 19).

\subsubsection{Preference Screening}

The objective of preference screening was to select a small number of contiguous areas likely to be suitable for development of traditional near-surface disposal facilities (aboveground/belowground), as well as new mined facilities or facilities developed from existing mines. To do this, the Commission applied selected preference criteria in three separate applications-one for near-surface methods, one for the new mine method, and one for disposal methods using existing mines. Each application included the basic set of preference criteria considered applicable regardless of disposal technology. For the near-surface application, criteria related to precipitation and stratigraphy were added to the basic criteria; for the new mine method, additional criteria related to geology were considered along with the basic criteria; and for existing mines, the results of the new mine screening were compared to maps of existing mines to determine if mines were already present within the potentially suitable areas.

Preference criteria were applied by using a standard scoring-weighting exercise. To the land still considered potentially suitable from exclusionary screening, the Commission applied 13 preference criteria for which screening data were available. Each $1-\mathrm{mi}^{2}$ grid not previously excluded was evaluated with respect to each criterion and given a score of 1,3 , or 5 for that specific criterion. 


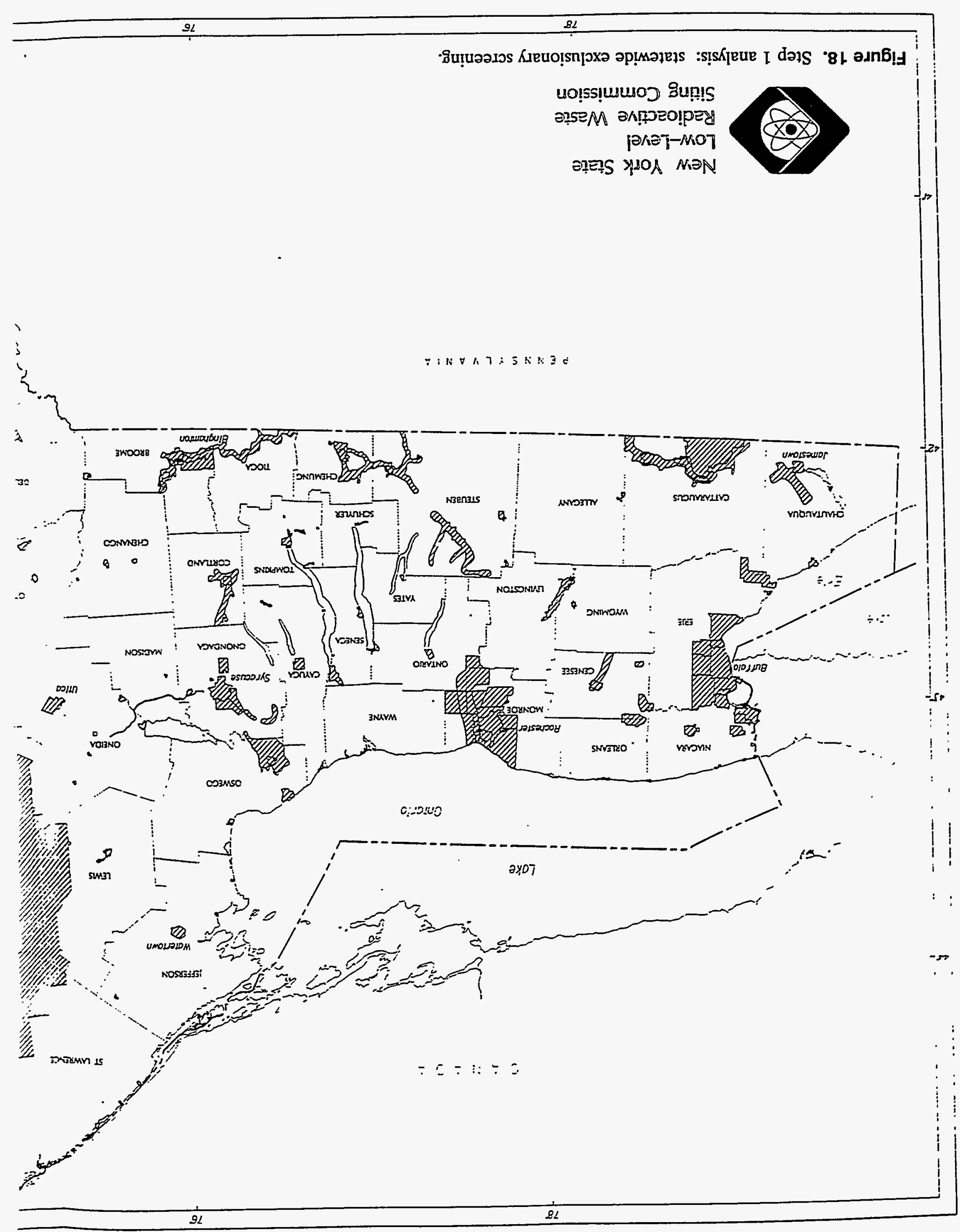




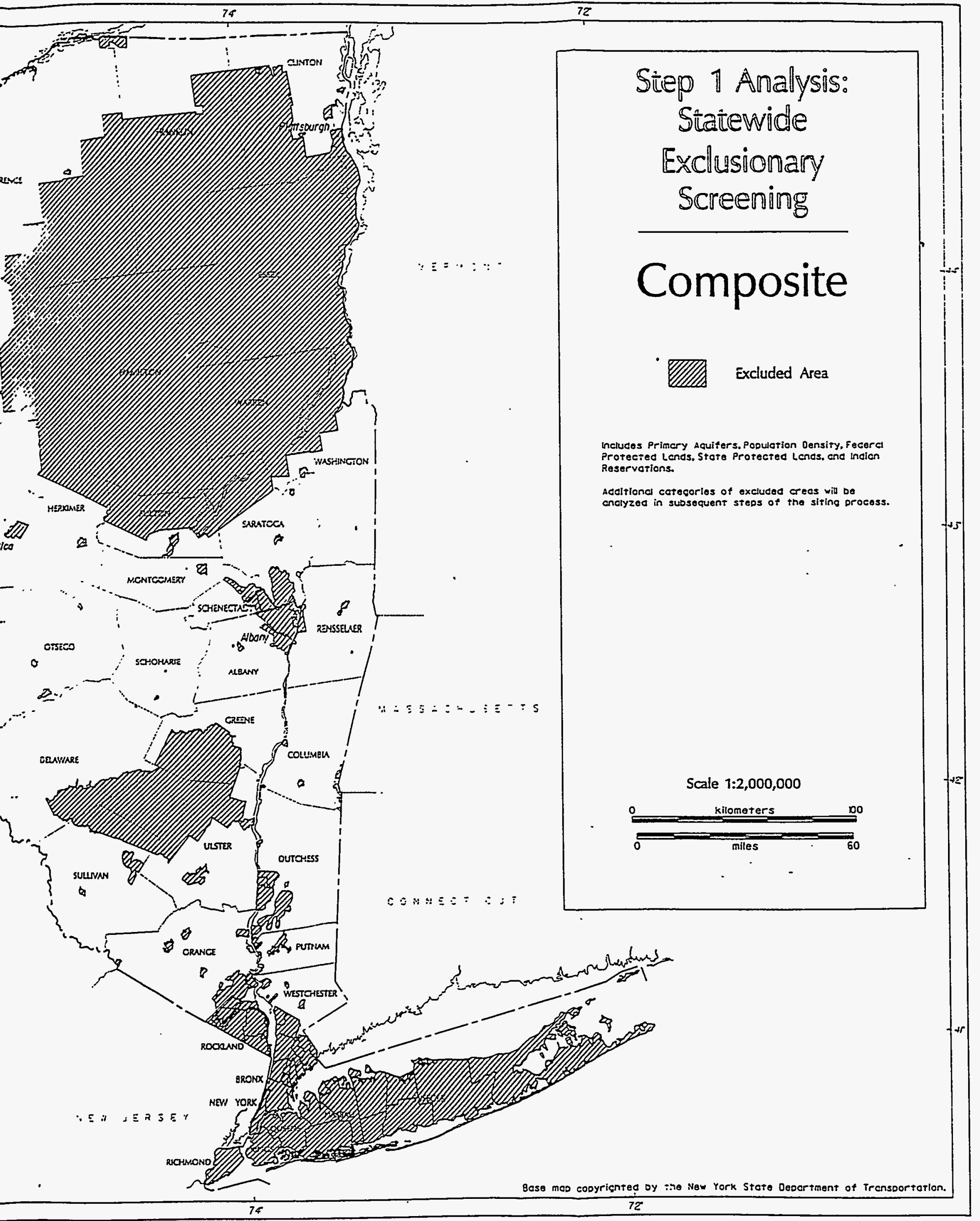




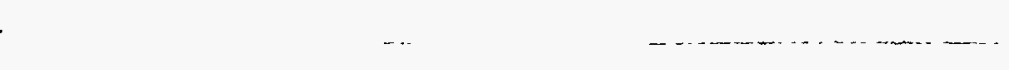


OL

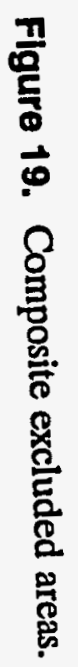

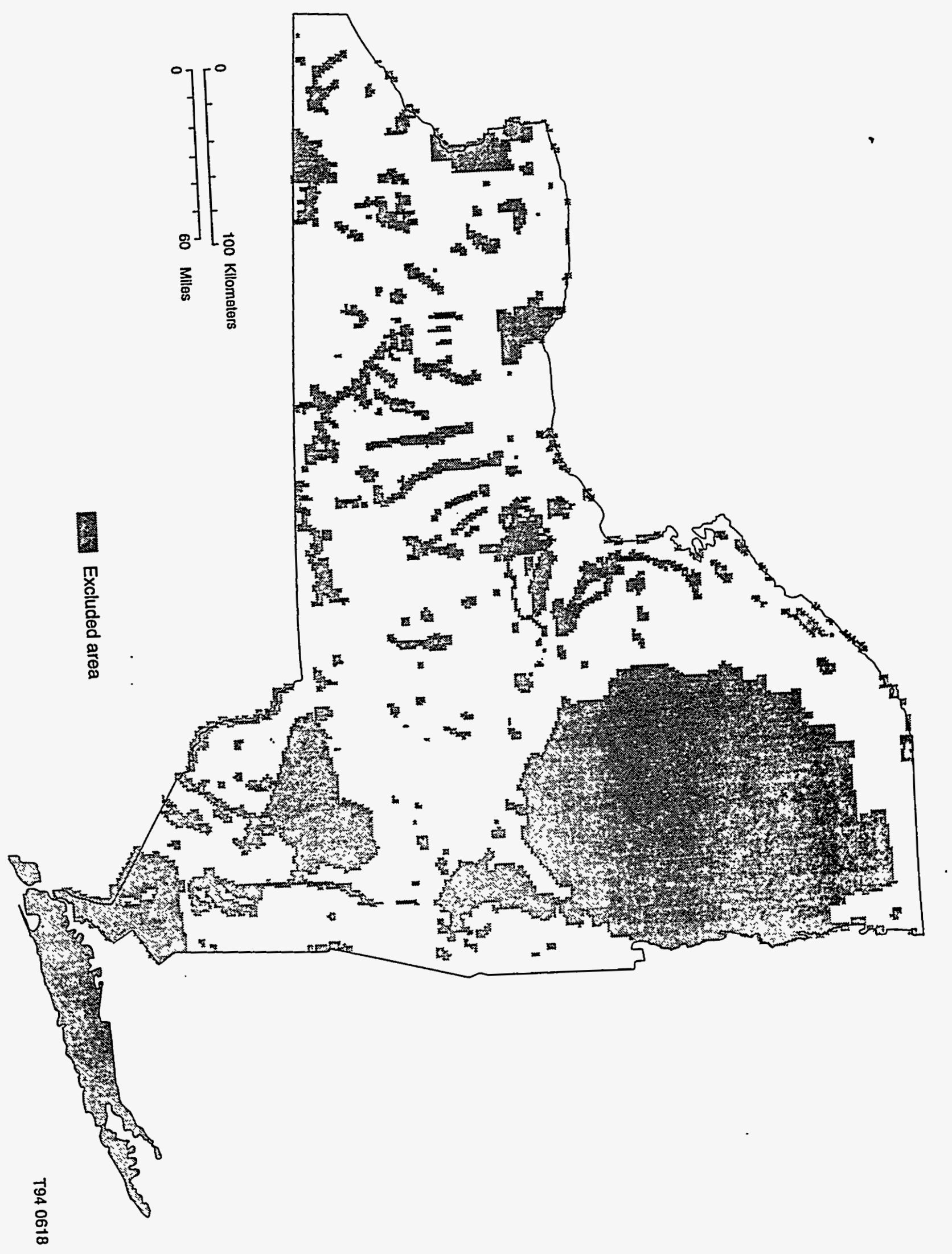


Because not all of the screening criteria were considered equal in importance, the Commission staff in November 1988 assigned each preference criterion a number representing its importance relative to the others. The staff derived these weights from two weighting workshops that had been conducted by the screening contractor in the previous months, one involving environmental organizations, site opponents, legislative representatives, and waste generators, and the other composed of the Commission staff. For each 1-mi cell within the eligible area, a score was assigned measuring the criterion with respect to the grid cell; then the score was multiplied by the weight of the criterion. A composite favorability score was calculated for each cell by adding the products of scores-times-weights for all of the preference criteria. Figure 20 is a color map showing composite favorability scores for areas of the State. In cases where the importance of criteria varied between common near-surface disposal concepts and mined facilities, separate weights were awarded to each. A separate composite map for new mine disposal methods was also generated.

Because the composite score for each 1-mi grid fell on a continuum between approximately 2,000 points and 5,000 points, the Commission staff and its screening contractor selected several cut-off values that might be used to distinguish areas that should be further evaluated from those that should be "set aside" or deferred from further consideration (see Section 11.3.5). The purpose in evaluating the results of several cut-off scores was to determine what cut-off score resulted in an optimum amount of land (not too much, not too little) to carry into the next substep of the process.

At this stage, the Siting Commission decided to use town borders to help draw the boundaries of candidate areas still under consideration. Boundaries for candidate areas were based on the following guidelines:

- A single town in which a large portion of grids exceeded a score of 4,700

- A group of contiguous towns in which a large portion of grids of each town exceeded a score of 4,400

- Where large portions of a town with grid scores exceeding 4,400 were contiguous to a candidate area as defined above, these portions of the town were also considered part of the candidate area.

Using this guidance, Weston outlined borders for 30 mutually exclusive potential candidate areas. Most of the areas consisted of from 1 to 10 entire towns. Several included portions of towns contiguous to the main cluster. After the exercise, approximately $5 \%$ of the State remained under consideration. The decision to use town borders at this stage to provide definition for potentially suitable areas avoided the kind of intermediate screening result experienced in Connecticut, where several hundred very small "potentially suitable areas" were spread throughout the State.

The final substep of Step 2 was to reduce the number of potential candidate areas from 30 to approximately 10 . This was done by a systematic, qualitative rating exercise. The staff of the Siting Commission, along with technical specialists from the siting contractor, assessed each of the 30 candidate areas as a whole with respect to selected criteria. For each criterion, an area as a 
whole was rated more favorable, favorable, or less favorable. The technical specialists based their rankings on a variety of available data and other information. Following the initial ratings, the technical contractor conducted "confirmatory assessments" to review the initial ratings in greater detail. One purpose of the confirmatory assessments was to determine whether any less favorable conditions within an area that were localized could be eliminated by simply adjusting the boundaries of the candidate area to exclude the location where the condition occurred. As a result of the confirmatory assessments, 11 specific modifications were made to areas or to the ratings of areas with respect to criteria. Table 5 shows technical ratings of the 30 potential candidate areas from this substep of Step 2.

Following the rating exercise, the staff (with support from Weston) prepared the Candidate Area Identification Report (CAIR), which recommended 10 of the candidate areas to undergo further evaluation. The report was presented to the Commission in a public meeting in December 1988. Figure 21 shows the 10 areas, which range in size from 49 to $162 \mathrm{mi}^{2}$ (Areas 22 and 23 were combined into a single area.). The basis for the selection is summarized as follows:

- Eight had been rated "more favorable" for aboveground/belowground disposal in the confirmatory assessment substep. Of these, three were considered to have good potential for mined disposal.

- One had been rated only "favorable" for aboveground/belowground disposal, but was selected because of its proximity to waste generators, a factor that the Commission upgraded in importance after the formal weighting exercise, based on public comment.

- One had been rated only "favorable" for aboveground/belowground disposal, but was located close to waste generators and also was considered to have good potential for mined disposal.

- One area rated only "favorable" in the formal rating process was selected, in part, because of its potentially superior geologic characteristics, which could only be assessed through further evaluation.

Step 3. Identification of potentially suitable sites. The step consisted of five distinct activities:

1. A GIS-based top-down screening exercise was used to help identify specific sites within the candidate areas.

2. A more qualitative rating exercise was used to reduce the number of sites under consideration.

3. Limited site inspections, or "windshield surveys," were undertaken to further reduce the number of sites.

4. A numerical scoring of the remaining sites was done using data that could not be applied during the earlier screening steps. 


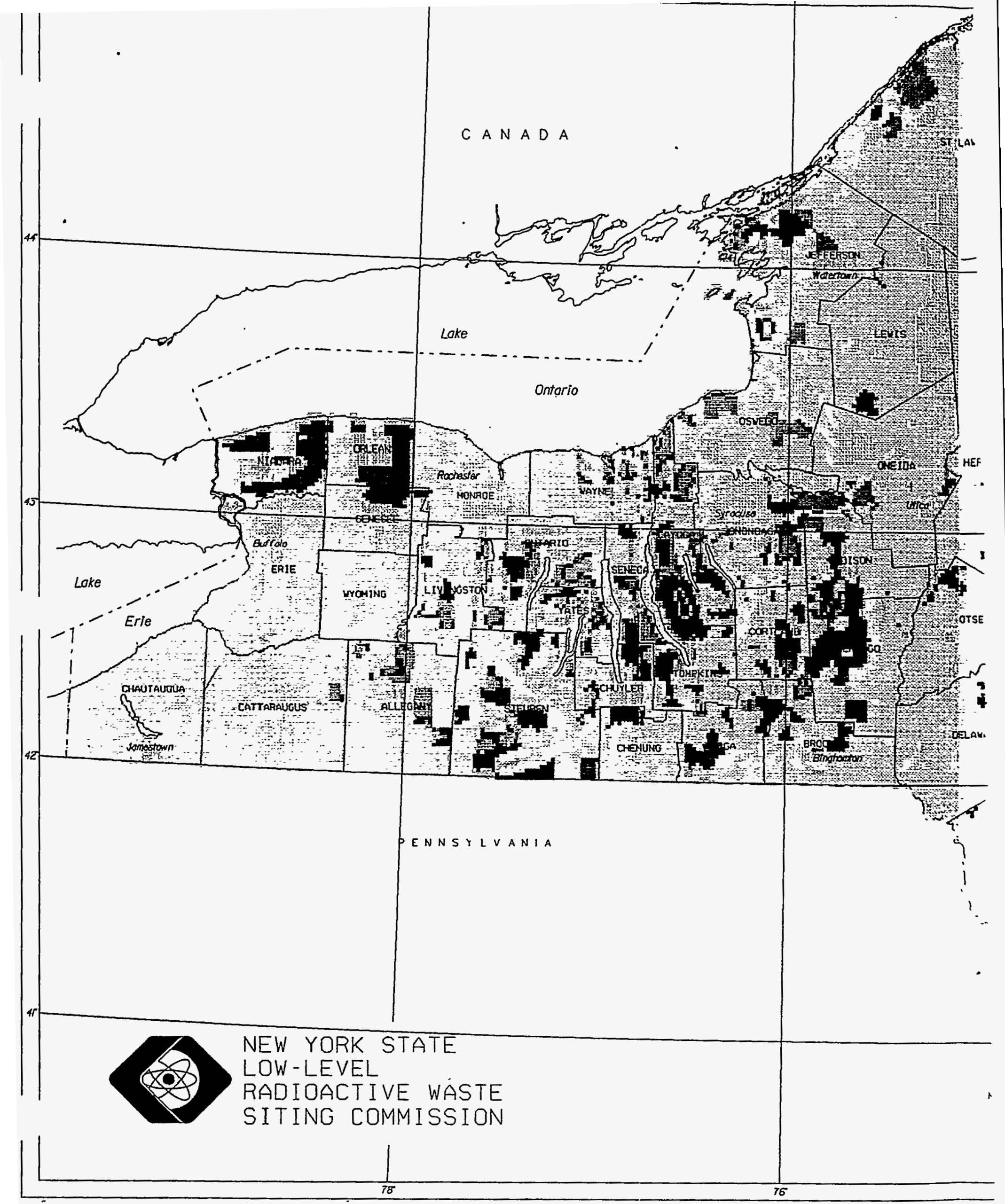

Figure 20. Composite favorability map. 


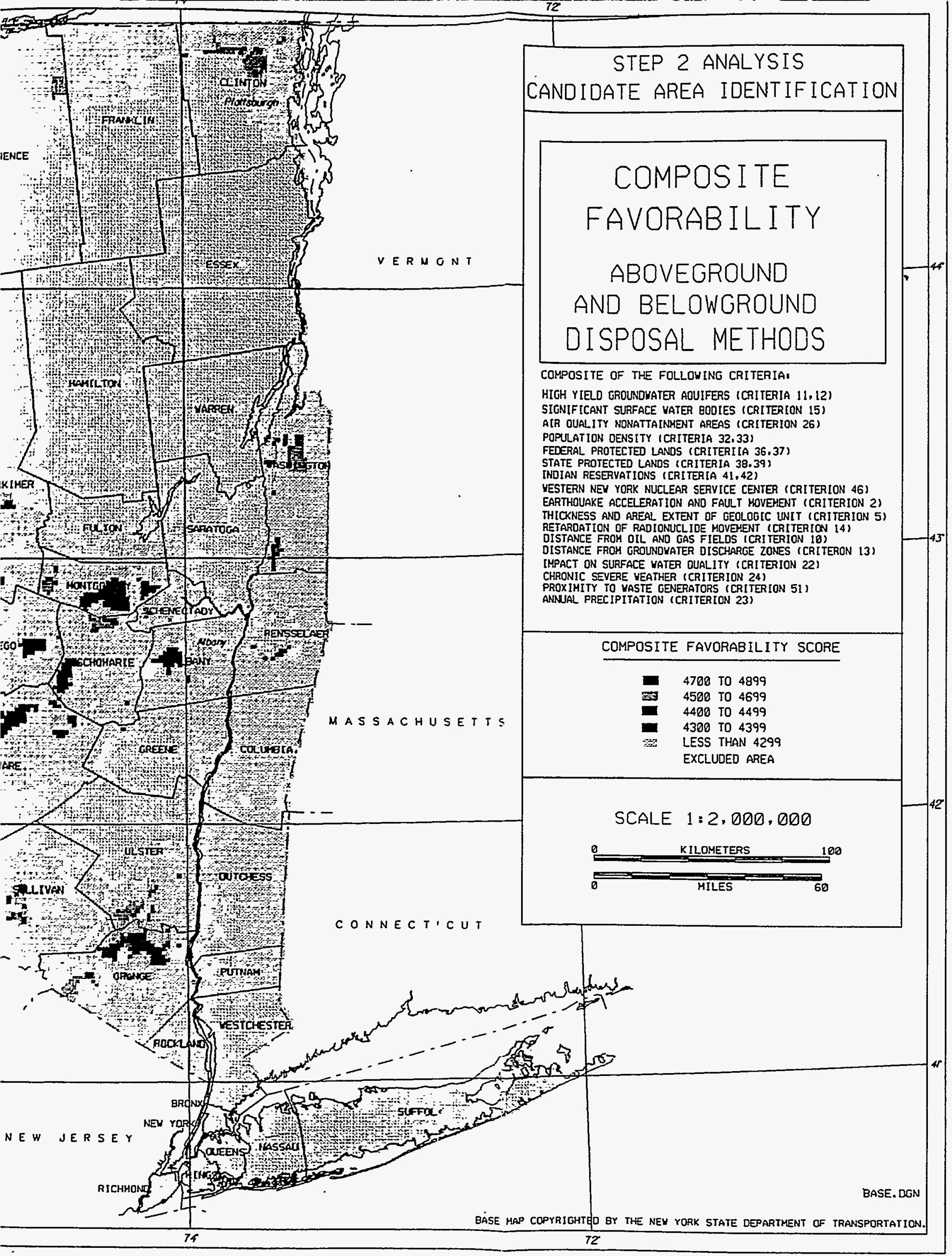




\begin{tabular}{|c|c|c|c|c|c|c|c|c|c|c|c|c|}
\hline \multirow[b]{2}{*}{-} & \multirow[b]{2}{*}{-} & \multirow[b]{2}{*}{-} & \multicolumn{10}{|c|}{ 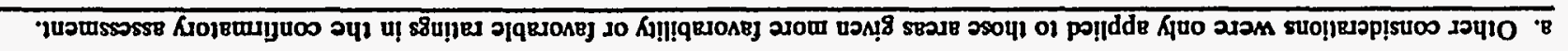 } \\
\hline & & & $\mathbf{X}$ & - & - & $\mathbf{X}$ & - & - & - & - & $\mathbf{x}$ & oE \\
\hline- & - & - & $x$ & - & - & - & $\mathbf{x}$ & - & - & - & $\mathrm{X}$ & $6 Z$ \\
\hline- & - & - & $\mathbf{x}$ & - & - & $\mathbf{x}$ & - & - & - & - & $\mathbf{x}$ & 82 \\
\hline- & - & - & $\mathrm{x}$ & - & - & $\mathrm{x}$ & - & - & $\mathrm{O}_{\mathrm{N}}$ & - & $x$ & $L 2$ \\
\hline- & - & - & $x$ & - & - & $\mathrm{x}$ & - & - & - & $\mathbf{x}$ & - & 9 \\
\hline- & - & - & $x$ & - & - & $=$ & $\mathbf{x}$ & - & - & $\mathrm{x}$ & - & $\Omega$ \\
\hline- & - & - & $\hat{x}$ & - & - & $\mathbf{x}$ & $\underline{-}$ & - & - & $=$ & $\mathbf{x}$ & +2 \\
\hline $180 M$ & ON & $\mathrm{ON}_{\mathrm{N}}$ & - & - & $\mathbf{x}$ & - & - & $\mathbf{x}$ & $\operatorname{sox}$ & - & $\mathbf{x}$ & $\varepsilon$ \\
\hline $150 M$ & ON & ON & - & - & $\mathrm{x}$ & - & - & $x$ & $\operatorname{sox}$ & - & $\mathbf{X}$ & $\tau z$ \\
\hline $\boldsymbol{O} \cdot \mathbf{N}$ & $\infty \pi$ & $\infty$ & - & - & $\mathrm{x}$ & - & - & $\mathrm{x}$ & ON & $\mathbf{x}$ & - & I \\
\hline- & - & - & $\mathbf{x}$ & - & $=$ & $\mathbf{x}$ & - & $=$ & - & $\mathbf{x}$ & - & $0 z$ \\
\hline- & - & - & $x$ & - & - & $\mathbf{x}$ & - & - & - & $x$ & - & 61 \\
\hline- & - & - & $x$ & - & - & $\mathrm{x}$ & - & - & - & - & $\mathbf{x}$ & 81 \\
\hline- & - & - & $\mathrm{x}$ & - & - & - & - & $\mathbf{x}$ & - & - & $\mathbf{x}$ & $\angle I$ \\
\hline$D-N$ & $\infty_{\lambda}$ & $\infty \pi$ & - & $\mathbf{x}$ & - & $\mathbf{X}$ & - & - & $\mathbf{O N}_{\mathrm{N}}$ & $\mathbf{x}$ & - & $9 I$ \\
\hline- & - & - & $\mathbf{x}$ & - & - & $\mathbf{x}$ & - & - & - & - & $x$ & SI \\
\hline D-N & $o_{N}$ & $\infty X$ & $x$ & - & - & - & - & $\mathbf{x}$ & ג & $\mathbf{x}$ & - & $b I$ \\
\hline 0- & $\mathrm{ON}_{\mathrm{N}}$ & ON & - & - & $\mathbf{x}$ & - & - & $\mathbf{x}$ & $\infty \alpha$ & $=$ & $\mathbf{x}$ & EI \\
\hline 5-日 & ON & ON & - & $\mathbf{x}$ & - & - & $\mathbf{x}$ & - & $\operatorname{sox}$ & - & $\mathbf{x}$ & ZI \\
\hline- & - & - & $\mathbf{x}$ & $=$ & - & $\mathbf{x}$ & - & - & - & $\mathbf{x}$ & - & II \\
\hline as & $\infty x$ & ON & - & $\mathbf{x}$ & - & - & $\mathbf{x}$ & - & $\mathbf{O}_{\mathbf{N}}$ & $\mathbf{x}$ & - & OI \\
\hline IsE & $\mathbf{O N}_{\mathbf{N}}$ & ON & - & $\mathbf{x}$ & - & - & $\mathbf{X}$ & - & ON & - & $\mathrm{X}$ & 6 \\
\hline $0-3$ & $\mathrm{o}_{\mathrm{N}}$ & $\operatorname{sox}$ & - & - & $\mathbf{x}$ & - & - & $\mathbf{x}$ & $\sin x$ & - & $\mathrm{X}$ & 8 \\
\hline $0-\bar{B}$ & $\mathrm{oN}_{\mathrm{N}}$ & ON & - & - & $\mathrm{x}$ & - & - & $\mathrm{x}$ & $80 x$ & - & $\mathrm{x}$ & $L$ \\
\hline- & - & - & $\mathbf{x}$ & - & - & - & $\mathbf{x}$ & - & - & - & $\mathbf{X}$ & 9 \\
\hline $\mathbf{G N}$ & $\mathrm{ON}_{\mathrm{N}}$ & ON & - & - & $\mathbf{x}$ & - & - & $\mathbf{x}$ & $\mathbf{O N}_{\mathbf{N}}$ & - & $\mathbf{X}$ & $s$ \\
\hline- & - & - & $\mathbf{x}$ & - & - & $\mathbf{x}$ & - & - & - & $\mathbf{x}$ & - & $b$ \\
\hline 158g & $\mathbf{O}_{\mathbf{N}}$ & $\infty \alpha$ & - & - & $\mathbf{x}$ & - & - & $\mathbf{x}$ & $80 x$ & - & $\mathbf{x}$ & $\varepsilon$ \\
\hline- & - & - & $\mathbf{x}$ & - & - & $\mathbf{x}$ & - & - & - & - & $\mathbf{x}$ & $z$ \\
\hline- & - & - & $\mathbf{x}$ & - & - & - & $\mathbf{x}$ & - & - & $\mathbf{x}$ & - & I \\
\hline \multirow[t]{2}{*}{ uo!neson } & 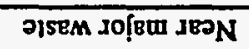 & su!̣ $\mathrm{MON}$ & 5507 & 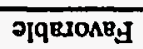 & गुON & sSP & गqसIOABy & 2Now & uolıвisadojo्d & วuाos & ग0 ma्य & Eary \\
\hline & & & \multicolumn{3}{|c|}{ 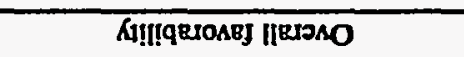 } & \multicolumn{3}{|c|}{ suol!̣puos souajoj21d } & \multicolumn{3}{|c|}{ 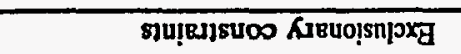 } & \\
\hline \multicolumn{3}{|c|}{ 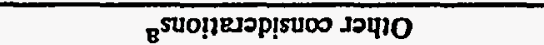 } & & OSSE KJolew & & \multicolumn{6}{|c|}{ ( ( Uo!̣100S) juatussosst on!̣lededtuon } & \\
\hline
\end{tabular}




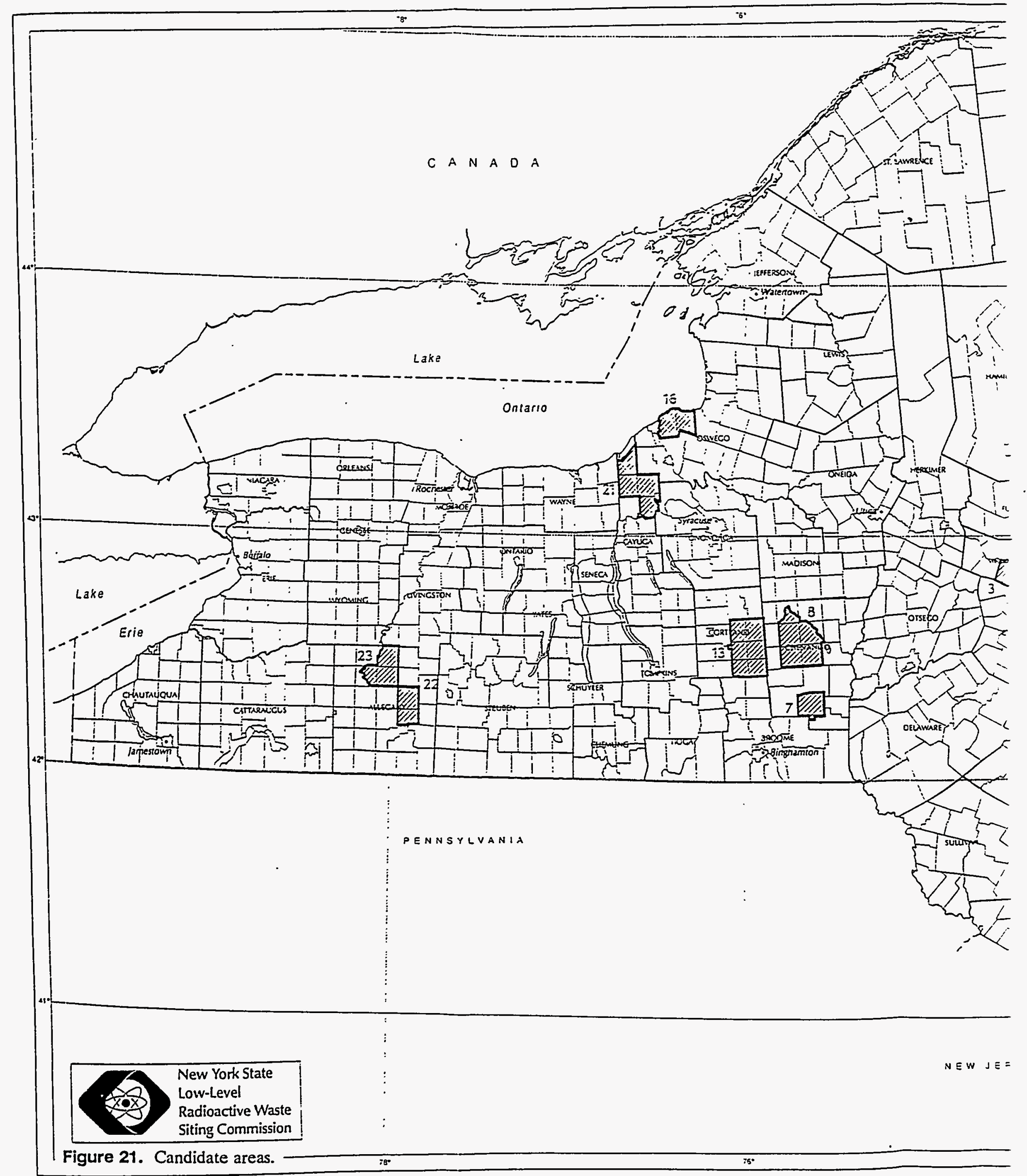




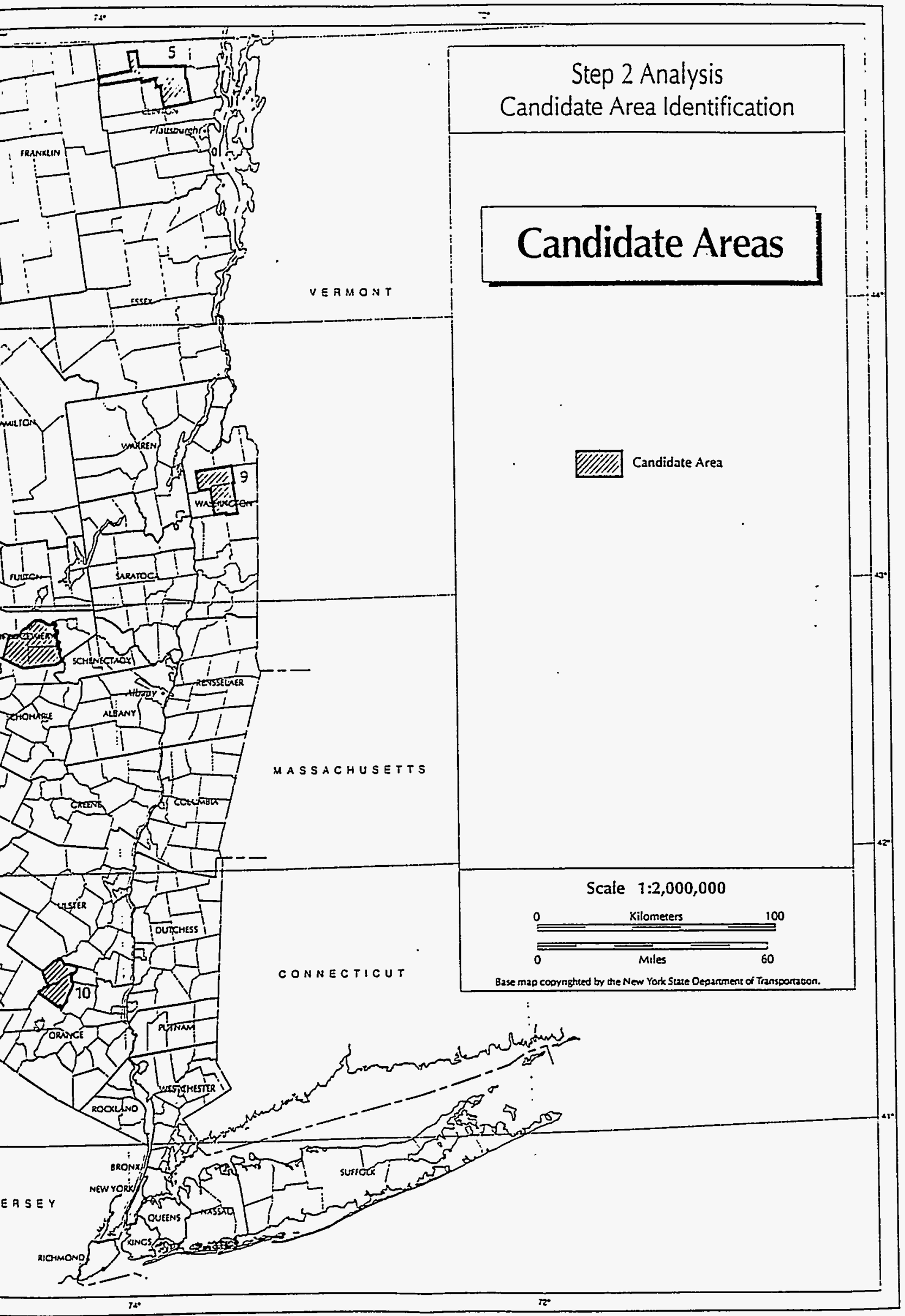


5. The Commission designated five of the sites for characterization, based on recommendations of the Commission staff.

\subsubsection{GIS Screening}

The top-down screening exercise that applied to the 10 areas was similar to that used to identify the areas within the State, except at a much smaller scale. Grids of 40 acres were used as the basic land units for comparison. As in the statewide and regional screening, if any portion of a grid contained an exclusionary feature, then the entire grid was considered unfavorable. A computerized GIS was used. Some criteria that had been used in the statewide screening with applicable data sets were reapplied at the area level with more specific data. In addition, some criteria not previously applied because of the lack of statewide data were applied at this step. New York documentation notes that, in many cases, data representative of applicable criteria were not already digitized and available for application, but had to be read into the database from published maps, lists, tables, and so on.

The process by which New York identified specific candidate sites from within potentially suitable areas differed from that used in Texas in at least one respect (see Section 10.4). In New York, the same criteria and data sets were used to screen all of the areas, while Texas tailored its process for screening each area to the specific characteristics of the area. The different strategies reflect the differing geographic characteristics of the two States.

As with statewide screening, the Commission used the weighting-scoring method in order to develop a composite rating for each grid. Weights for the various criteria were those developed during the earlier workshops. Criteria that might have differing importance to common, near-surface disposal concepts than to drift mine disposal were given separate weights for each disposal method.

At the conclusion of GIS screening, 96 sites were identified. The sites were clusters of at least five 40-acre grids, each of which exceeded a numerical threshold from the weighting-scoring exercise.

\subsubsection{Qualitative Rating of Sites}

The next task was to select from among the 96 sites those that would undergo further evaluation. To do this, the staff and technical contractor rated each site by assigning a plus, zero, or minus value to each site based on a qualitative evaluation against several key criteria:

- $\quad$ Proximity to incompatible structures

- Soil groups and agricultural activity

- Drainage (not applicable to drift mines)

- Slopes

- Transportation access. 
Under this evaluation, 79 of the 96 sites received relatively high ratings. This number was reduced to 51 by eliminating the smaller sites that were less likely to provide at least 400 acres for the disposal site and an ample buffer area. In addition, four sites offered by landowners were added to the list of sites to undergo further consideration. Two of the four were within candidate areas identified in Step 2. Sites selected for limited inspection in the next step were located, in descending order by the number of sites, in Allegany, Chenango, Cortland, Clinton, Montgomery, Oswego, and Washington Counties.

Each of the remaining sites underwent a "windshield survey." Two teams, consisting of the staff of the Commission and the technical contractor, used standard procedures and checklists to record applicable features of each of the sites. For each of the sites, survey teams recorded their observations of "major siting constraints" and "other siting concerns." Table 6 is one page from a table documenting the observations on the sites. Following the surveys and consultation with individual members of the Commission, the staff and contractor selected 19 sites considered to have conditions superior for siting.

\subsubsection{Site-Specific Scoring}

In order to provide additional information to assist the Commission in selecting sites to undergo precharacterization, the Commission staff and its technical contractor rated each of the 19 sites. For each site, the participants assigned a score relative to each of the applicable criteria. The value or weight of each criterion was taken from the earlier weighting workshops. The composite score for each site was based on the sum of scores-times-weight for the site for all the applicable criteria. Criteria additional to those available in the GIS system were used for the exercise.

\subsubsection{Designation of Five Sites for Precharacterization}

It was the responsibility of the Commission staff to recommend four to eight sites to undergo precharacterization work. Because data and information on each of the sites were diverse, consisting of the results of rating exercises, windshield surveys, and voluminous information submitted by communities in which the sites were located, the final recommendation did not lend itself to a simple formula. In a series of meetings of staff and the technical contractor, the features of each site were reviewed and evaluated against the others. In a process of stepwise elimination, five sites were selected for recommendation to the Commission.

Recommendations of the staff were based heavily on the table of numerical scores that resulted from the GIS preference screening and the site-specific evaluations. The five sites recommended by the staff were each ranked highly by the composite scores. Other factors cited by the staff were:

- The complexity of ownership of the sites (that could potentially affect their acquisition)

- The potential for future development for other uses

- The productivity of soils for agriculture 
Table 6. Results of limited site inspections of sites set aside.

\begin{tabular}{|c|c|c|c|}
\hline Candidate area & Site no. & $\begin{array}{l}\text { Major siting } \\
\text { constraints }\end{array}$ & Other siting concerns \\
\hline \multirow[t]{30}{*}{ Allegany } & $22-1$ & - & Poor drainage \\
\hline & & - & Flooding potential \\
\hline & & - & Potential wetlands \\
\hline & & - & Potential soil creep \\
\hline & & - & Seeps and springs \\
\hline & & - & Ponds onsite \\
\hline & & - & Road construction required \\
\hline & & - & Insufficient slopes for mine \\
\hline & $22-4$ & - & Poor drainage \\
\hline & & - & Hydric soils \\
\hline & & - & Nearby quarries \\
\hline & & - & Nearby recreation area \\
\hline & & - & $\begin{array}{l}\text { Creek in potential areas for drift } \\
\text { mine }\end{array}$ \\
\hline & $22-6$ & - & Poor internal drainage \\
\hline & & - & Seeps \\
\hline & & - & $\begin{array}{l}\text { Steep slopes but marginal for } \\
\text { drift mine }\end{array}$ \\
\hline & & - & Sheet and gully erosion \\
\hline & & - & Thin till \\
\hline & & - & Potential nonresident population \\
\hline & $22-7$ & - & $\begin{array}{l}\text { Poor drainage; ponding and } \\
\text { flooding }\end{array}$ \\
\hline & & - & Potential wetlands \\
\hline & & - & Potential springs and seeps \\
\hline & & - & Quarry \\
\hline & & - & $\begin{array}{l}\text { Flooding from upstream } \\
\text { impoundment }\end{array}$ \\
\hline & & 一 & Potential nonresident population \\
\hline & & - & Road improvements required \\
\hline & $22-8$ & Active gas wells & Variable drainage \\
\hline & & & Pond on site \\
\hline & & & Potential springs and seeps \\
\hline & & & Road improvements required \\
\hline
\end{tabular}


- The size and shape of the sites

- The ability of the sites to support common abovegrade/belowgrade disposal concepts, or drift mine disposal

- Geographic diversity (to reduce the chances that a flaw discovered in one site might afflict the other candidate sites).

Two of the recommended sites were in Cortland County and three were in Allegany County. The sites ranged in size from approximately $3 / 4$ to more than $1-1 / 2 \mathrm{mi}^{2}$, and all were considered by the Commission to be suitable for a variety of aboveground and belowground disposal methods. Figure 22 shows the location of the five sites within the two counties. Figure 23 shows the boundaries of one of the candidate sites in Cortland County. Following a technical presentation by the Commission staff and its technical contractors on September 1989, the New York Siting Commission designated the five recommended sites for further evaluation during the preliminary characterization phase.

Step 4. Selection of sites for characterization. The Commission staff and its technical contractors attempted to conduct preliminary characterization activities at the five candidate sites, but were physically prevented from doing so by opponents of the sites. Facing the escalating chance of violence, the governor requested that the Commission suspend further onsite activities pending an evaluation of the siting and disposal method selection processes.

\subsection{Final Site Selection}

New York's low-level radioactive waste legislation was amended in 1990 in response to opposition in Allegany and Cortland Counties to the candidate sites that had been selected. The amendment made several significant changes related to site selection. The amendment to the law required the Siting Commission to select a disposal method before resuming the site selection process.

The commission shall select as its preferred disposal method that method which is projected best to meet applicable regulatory criteria and performance objectives and maintain exposure to the general public as low as reasonably achievable, taking into account engineering and economic feasibility compared to other available disposal methods. An Environmental Impact Statement is required in support of the decision. [Environmental Conservation Law, section 29-0303(2)]

The amendment also required the Siting Commission to issue a report on lands "excluded from consideration for siting." The report is to serve as a basis for independent evaluations by the State's CAC and by an independent technical and scientific evaluation panel. The report was completed in 1993.

Although the amendment to the law does not prescribe any specific action in response to the evaluations of excluded land, the outcome of the evaluation will likely influence a decision by the Siting Commission or the legislature on whether the siting process should be continued where 


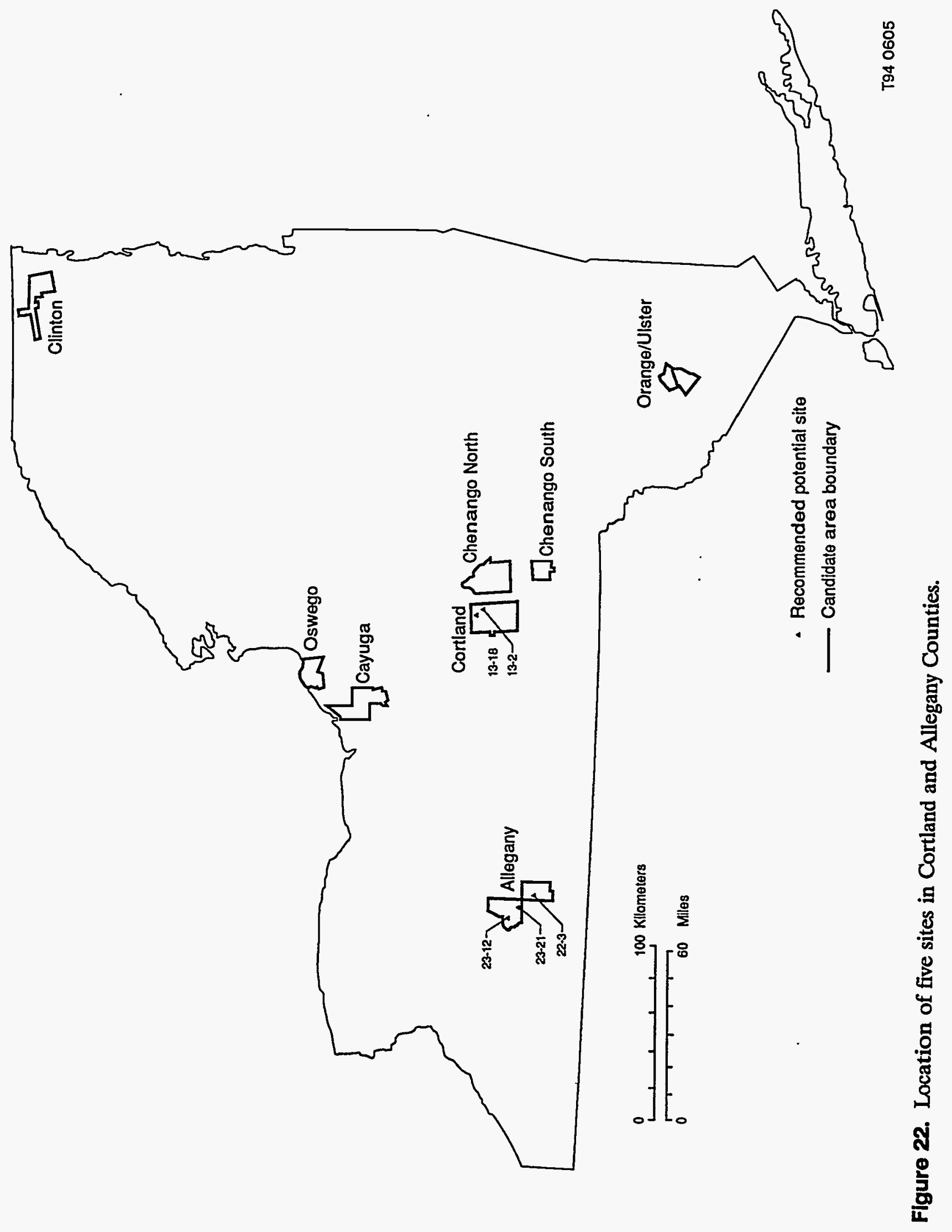




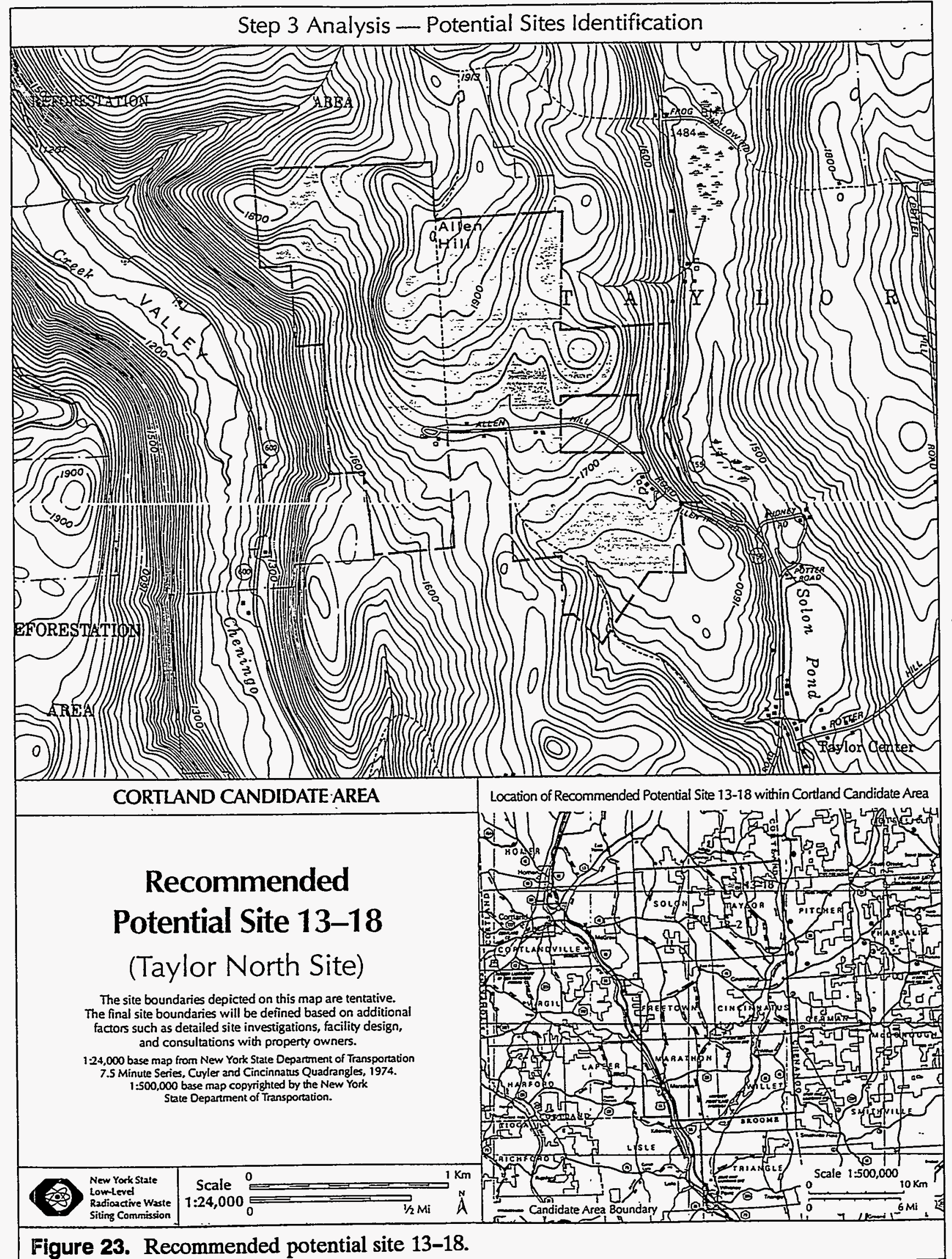


it was suspended, continued from an earlier phase, or revised completely. The 1990 amendment also did not address the continuing status of the five preferred sites already identified.

On May 11, 1993, the Siting Commission voted that the sites would no longer be considered "preferred sites," pending a decision by the Department of Environmental Conservation on the Siting Commission's recommendation of a disposal method. The Commission also directed its staff to develop a process for soliciting volunteer communities to host the disposal facility. 


\section{NORTH CAROLINA-SOUTHEAST COMPACT REGION}

The Southeast compact region consists of Alabama, Florida, Georgia, Mississippi, North Carolina, South Carolina, Tennessee, and Virginia. The Compact Commission designated North Carolina as the region's second host State in September 1986. The current host State is South Carolina, which plans to provide disposal access at its Barnwell County facility through 1995 for low-level radioactive waste generated within the region.

North Carolina enacted legislation on August 13, 1987, creating the North Carolina LowLevel Radioactive Waste Management Authority (Authority), which is responsible for siting, design, construction, operation, and closure of a disposal facility. The Authority entered into an agreement with Ebasco Services, Inc., to develop and initiate a site selection program. On July 28, 1989, the Authority entered into a contract with Chem-Nuclear Systems, Inc. (CNSI) to complete site selection, and to design, build, and operate the facility.

\subsection{Status}

After conducting preliminary characterization work at four sites, CNSI recommended to the Authority that two sites be fully characterized, one in Richmond County and the other straddling the border between Wake and Chatham Counties (the Wake/Chatham site was later reduced in size and is wholly contained in Wake County). Site characterization plans developed by the Authority were approved by the Department of Environment, Health, and Natural Resources' Division of Radiation Protection on August 16, 1991, and site characterization began immediately on the Wake/Chatham site. A restraining order brought by Richmond County delayed the characterization activities on the Richmond site until January 1992. Following characterization, CNSI prepared license applications for both sites. In an open meeting, December 7 and 8, 1993, the Authority voted 14 to 0 to submit the license application for the Wake site to the Division of Radiation Protection for review.

\subsection{Legal and Regulatory Framework}

The North Carolina Low-Level Radioactive Waste Management Authority Act of 1987 (Chapter 104G of the General Statutes) does not prescribe a particular siting method, except to direct that, "The Authority shall actively seek communities interested in hosting low-level radioactive waste facilities" (104G-9). However, the law does require the "procedures and criteria" for siting to be codified through a rulemaking process by the Low-Level Radioactive Waste Management Authority. The law provides the Authority the power of eminent domain, suggesting that a nonvoluntary approach (e.g., a top-down screening method) is also sanctioned under the law.

Regulations governing siting appear in two different parts of the North Carolina Administrative Code (NCAC). Section .1200, Chapter 11, of Title 15A includes regulations substantially equivalent to those in Federal regulations, 10 CFR Part 61.50, describing technical specifications for the disposal site in general terms (see Section 1.2). 
The Authority issued more specific regulations and procedures pursuant to the Management Authority Act in August 1988. The regulations, Title 1, Chapter 37, August 1, 1988, are relatively nonprescriptive as to the type of process to be used, leaving the Authority with considerable flexibility in the design and execution of the siting program. The Authority is required to "identify areas that may be suitable" for the disposal facility (Section .0302), and is required to select at least two potentially suitable sites (Section .0304). The regulation does not explicitly require that the two or three sites be selected from potentially suitable areas identified in a screening process, and the term, "areas," is not defined in the regulation.

The Authority's rules prescribe procedural safeguards for communities in which a designated site is located. They also set forth a number of factors that must be "considered" in site selection (Section .0200). Among these are a requirement that the Authority consider local land uses, including "use of large land holdings by utilities or other industries, including land adjacent to nuclear power plants." Although the factors are called "criteria" in the regulations, they are presented in a manner that requires adaptation into more specific statements that lend themselves to measurement prior to application in a site evaluation or screening process.

The Authority's request for proposals for a contractor to assist in site selection asked bidders to propose a complete methodology for identification of candidate sites. Each of the proposals recommended a top-down screening method for site selection using the entire State as the initial study area. Although the State's law and regulations do not explicitly require that the site be selected through a geotechnical screening process (as opposed to a volunteer community approach, for example), Authority staff believe that those involved with development of the law anticipated that the Authority would employ a geotechnical screening approach.

In August 1993, the Authority amended its siting regulations to codify the process by which the Authority was to select which, if any, of the two fully characterized sites for submission of a license application.

\subsection{Siting Criteria}

Ebasco prepared measurable siting criteria based on the guidance and direction provided in the State law and in the State and Federal regulations. Using the format in the North Carolina General Statutes GS 104G-9, the Authority divided the applicable State and Federal siting requirements into six major factor groups, with subcategories under each:

- Hydrological and geological factors

- $\quad$ Surface water

- Groundwater

- Geology

- Geologic stability

- Soil characteristics 
- Environmental and public health factors

- Water quality/public drinking water quality

- Demography and population growth

- $\quad$ Air quality

- Natural and cultural resources

- $\quad$ Parks and forests

- Wildlife protection areas

- Areas of scenic importance

- Areas of historical, cultural, religious, ethnic, or racial importance

- Local land use

- Proximity to activities pumping large quantities of water, quarry blasting, uses of conflicting sources of radioactivity, and to military facilities and lands.

- Land ownership by utilities and other industries, particularly in proximity to nuclear power plants.

- Transportation

- $\quad$ Proximity to major highways and waste generators

- Route safety

- Method of transportation

- Aesthetics

$\begin{array}{ll}\text { - } & \text { Visibility } \\ \text { - } \quad \text { Appearance } \\ \text { - } \quad \text { Noise levels. }\end{array}$

A total of 55 criteria were developed under these areas. Each was written so as to be an exclusionary criterion ("The site shall be located outside of ..."), or a "site suitability" criterion ("Sites are preferred that ..."). Data associated with each criterion were also examined to determine whether the criterion could be applied at the statewide level. Ebasco noted that, "virtually all of the criteria applied at the statewide screening phase will be reapplied at a smaller, more local scale during the subsequent phases of the study."

In November 1988, the legislative Joint Select Committee on Low-Level Radioactive Waste adopted a resolution that, "Priority should be given to characterization of a site on land owned or controlled by a public utility in proximity to a generating nuclear power reactor."

\subsection{Site Selection Process}

Statewide screening was initially performed by Ebasco under the direction of the Authority. Ebasco conducted Phase 1 and 2 of screening, which produced a number of potentially suitable 
site areas. After the Authority contracted with CNSI, that company completed the screening process, recommending two candidate sites for full characterization.

\subsubsection{Application of Exclusionary Criteria}

Phase 1 screening involved identification and application of exclusionary criteria for which data were available at the statewide level. The statewide exclusionary criteria (called site "requirements" in the report Phase 1 Screening Study: Identification of Potentially Suitable Areas, by Ebasco Services, Inc., November 30,1988) required potentially suitable areas to be:

- Outside swamps in excess of 500 acres, contain no lakes greater than 500 acres, outside the coastal high hazard area, and outside the areas where all the land is subject to periodic flooding

- Outside areas where all the land has a seasonally high water table within $6 \mathrm{ft}$ of the surface

- More than $1,000 \mathrm{ft}$ from a municipal water well

- At least $2 \mathrm{~km}$ from the boundary of population centers

- $\quad$ Outside national forests, State forests, national parks, State parks, Federal wildlife refuges, State-owned gamelands, designated wilderness areas, scenic rivers, and Indian reservations

- $\quad$ Outside the boundaries of military facilities and lands.

Several different map scales were used to build the database and to report the results. A set of nine maps at the largest mapping scale possible, 1:250,000, was used to cover the entire State. Next, each criterion was mapped by hand on a separate set of base maps using publicly available data sources. The base map sets were then overlain by $53,4001-\mathrm{mi}^{2}$ grid cells. For each individual criterion or data set, a grid cell was deferred from consideration in the subsequent phase of screening if any portion of land within the cell contained the exclusionary condition. The Authority did not consider such deferral to be an outright "exclusion" because of the potential for the grid cell to contain considerable land area without the exclusionary condition. (Section 11.3.5 discusses the distinction between excluding land and deferring land from consideration.) At the end of Phase 2, potentially suitable areas were defined to include unaffected land area in grid cells deferred because of the presence of an exclusionary condition elsewhere within the grid (see Phase 2, below).

This process of overlaying grid cells onto the exclusionary maps for each criterion allowed the results for each grid cell to be encoded into a computer database in order to generate composite results.

Potentially suitable areas that resulted from this process were the composite of all the grid cells that had not been deferred by one or more of the data sets. This was about $38 \%$ of the State, or 13.1 million acres $\left(20,446 \mathrm{mi}^{2}\right)$. For purposes of presentation and reporting, the mapped 
output from the computer database was converted to scales of $1: 1,000,000(1 \mathrm{in} .=16 \mathrm{mi})$, and 1:2,000,000 ( 1 in. = $32 \mathrm{mi}$ ) using a high-precision mechanical plotter (see Figure 24). Like a television picture composed of thousands of dots, this "down-scaling" of the results has the effect of smoothing the grid-like nature of the base maps.

On the composite map, areas in the coastal regions of the State were largely excluded because of surface water criteria, areas in the west because of natural and cultural resource criteria, and the excluded areas in between are due largely to proximity to population centers.

Unlike the top-down screenings performed by some of the other States, North Carolina's process avoided the use of weighted and scored preference criteria, choosing instead to phrase all the criteria for which data could be applied at this scale in a manner that would lend themselves to an "in or out" result for each 1-mi grid.

At the conclusion of Phase 1, the Authority initiated a program involving six informational public meetings and 26 community forums at various locations within the potentially suitable areas. The community forums were designed, in part, to stimulate interest in potential volunteer host communities without requiring local officials to indicate a commitment one way or the other, at this stage. No communities asked to be considered for the facility in response to the initiative.

\subsubsection{Identification of Potential Siting Areas}

The objective of the second phase was to identify "potential site areas" larger than 150 acres. This was done in three "tasks." The first task was to narrow the amount of land under active consideration by conducting an initial suitability screening at the same 1:250,000 scale used in Phase 1. Nine and one-half percent of state remained eligible after Task 1.

In Task 2, further exclusionary screening was done in the areas remaining eligible after Task 1, but at a smaller 1:100,000 scale. Later in Task 2, the boundaries of "suitable site areas" were determined by shifting to 1:24,000-scale USGS quadrangle maps and changing to 1/4-mi grids (160 acres). The "seed cell," or starting point, for a suitable site area was a grid in which all the land area met certain conditions. They were:

- More than $50 \%$ of the grid had soils mapped on Soil Conservation Service soil association maps as having groundwater depth greater than $6 \mathrm{ft}$

- The grid had slopes generally less than $2 \%$

- There were no churches, cemeteries, schools, prisons, rest areas, or historical monuments as shown on Department of Transportation county road maps, or USGS quadrangle maps

- There were no perennial streams or "swamps."

Site boundaries extending outward from the seed grid were hand-drawn around all contiguous land that did not violate any of the criteria, irrespective of grid boundaries. Onehundred sixteen suitable site areas were identified, comprising $0.2 \%$ of the State. 


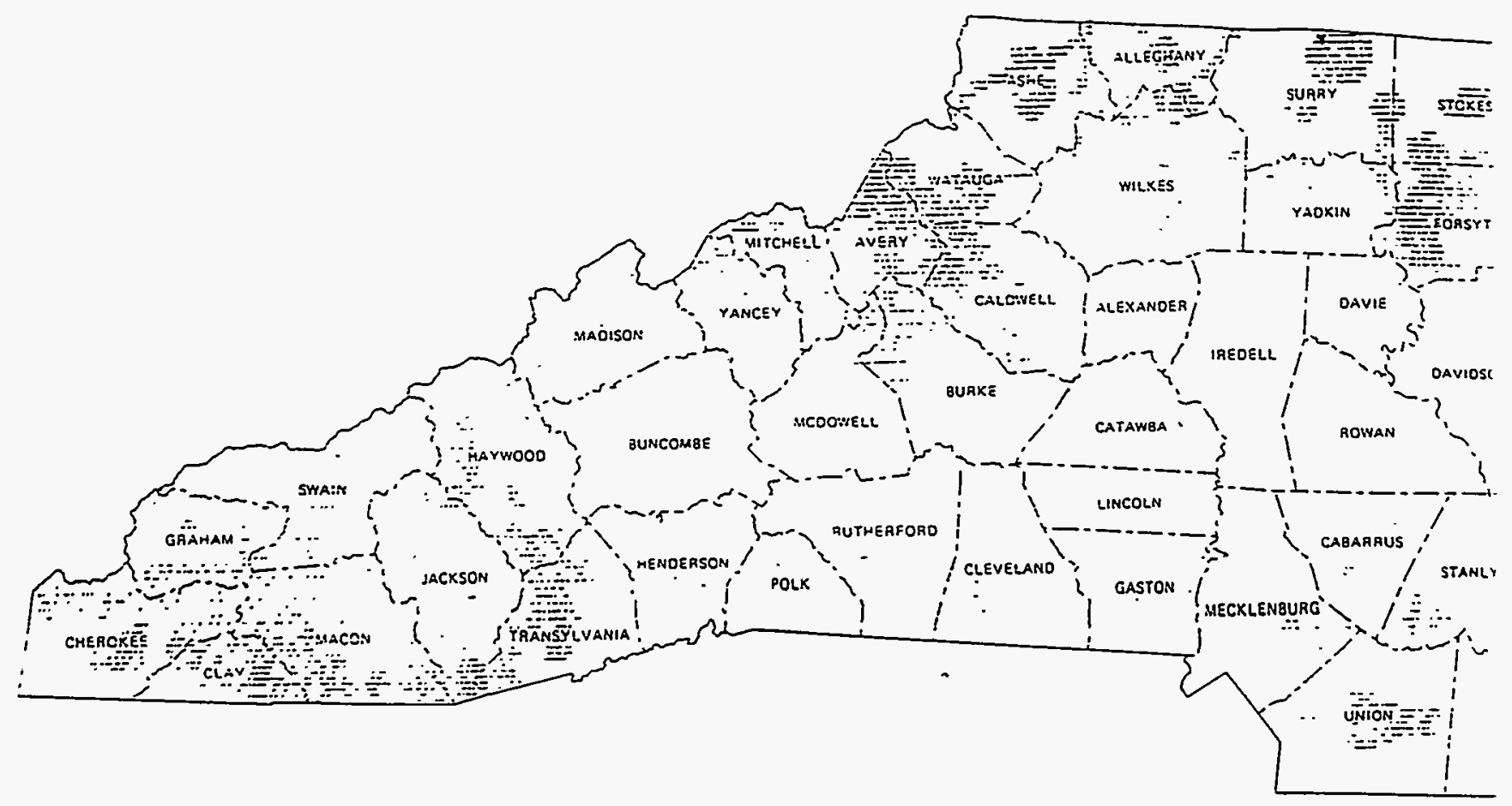

\section{EXPLANATION}

The shaded area on this map represents the composite of the shaded areas shown on Plates 1 through 6, as follows:

$$
\begin{aligned}
& \text { - Plate } 1 \text { - Surface Water } \\
& \text { - Plate } 2 \text { - Groundwater } \\
& \text { - Plate } 3 \text { - Municipal Water Supply Wells } \\
& \text { - Plate } 4 \text { - Population Cemters } \\
& \text { - Plate } 5 \text { - Natural and Cutural Resources } \\
& \text { - Plate } 6 \text { - Miltary Faciltles and Lands }
\end{aligned}
$$

Areas in white (nol shaded) are Kentifled as Polentlally Suntable Areas.

It should be noted that the Poxentially Suitable Areas have been defined sclety on the basis of the Ilsted criteria, and that this evaluation was based on cata available at a statewide scale. Subsequent phases of the Dased on cata available at a statewide scale. Subsequent phases of the these areas using both these and additional criterta.
STA

DISF

PHA

IDE!

Figure 24. Potentially suitable areas. 
Among the 116 site areas was one area located about $2 \mathrm{mi}$ from the Shearon Harris nuclear station, and partly owned by Carolina Power and Light Company. Although initially deferred in the screening exercise, the site area (along with other deferred areas near nuclear power reactors), was reconsidered based on field reconnaissance after the legislative Joint Committee on Low-Level Radioactive Waste indicated its preference for sites located in proximity to nuclear power reactors (see Section 9.3).

\subsubsection{Selection of Sites for Characterization}

The Authority had initially planned for the siting contractor, Ebasco, to complete the site selection process down to two or three specific site areas for characterization. Once CNSI entered into a contract to become site operator-designee, however, the Authority decided to transfer responsibility for the final phase of site selection to CNSI, requiring that the company first review all of the Ebasco work and attest to its validity.

In order to further narrow the number of sites under active consideration, CNSI recommended and the Authority adopted additional site conditions and methods for applying site criteria. These included expansion of the minimum site area from 150 acres to 500 acres, including a buffer area, and requiring the site buffer area to be of a technical quality similar to the site itself. Hydrological factors used to infer depth of groundwater, site slope, engineering feasibility, and protection of the population from radioactivity were also considered. With these requirements, CNSI reduced the number of candidate site areas to 21 . In September 1989, CNSI staff conducted field reconnaissance of each of the 21 sites using a standard checklist to note applicable site conditions.

In October, CNSI's project team held a two-day working session to review the results of the site visits and other information in order to further narrow the number of sites under active consideration. As a result of these qualitative discussions, nine sites were selected for further study. Of these, four that were located in watershed areas were deferred, leaving site areas in five locations. These were in Wayne, Rowan, Union, and Richmond Counties, and one on the border of Wake and Chatham Counties. Soon thereafter, the site area in Wayne County was deferred because of new information indicating a high water table.

On November 8, 1989, following a technical presentation on the sites, the Authority approved the recommendation to conduct preliminary characterization of the Wayne, Rowan, Richmond and Wake/Chatham County sites. Preliminary characterization studies were conducted between November 1989 and February 1990, with the goal of recommending at least two of the areas for detailed characterization. In March 1990, following preliminary characterization of the four sites, the Authority removed the Rowan and Union County sites from consideration. On April 30, the Authority authorized CNSI to characterize the Richmond and Wake/Chatham sites.

\subsection{Final Site Selection}

An amendment to the Authority's siting regulations, NCAC 37, dated August 30, 1993, required final designation of a preferred site to be made by a role call vote of the Authority members. The rules specified that each eligible voting member vote for one or the other of the 
characterized sites, or neither of the sites, or vote "undecided." The decision would be based on a majority of the members voting.

Characterization at the Wake/Chatham and Richmond County sites was completed, and license applications were prepared for both sites. On December 7 and 8, 1993, the Authority held a two-day open meeting in Raleigh to review the results of the site studies and decide whether to submit one of the license applications for review. Following technical presentations and discussions of each of the criteria areas, the Authority voted 14 to 0 to submit the license application for the Wake site for review. While noting some differences between the two sites in each of the criteria areas, a number of the Authority members commented on the potential disruption that might be caused in moving some 149 residents from the Richmond County site. By contrast, no one resides on the Wake County site. 


\section{TEXAS-UNAFFILIATED STATE}

Texas was the first State to enact enabling legislation in response to the Federal Low-Level Radioactive Waste Policy Act of 1980. The Texas Low-Level Radioactive Waste Disposal Authority Act was enacted June 1, 1981. The law established the Texas Low-Level Radioactive Waste Disposal Authority to site, construct, operate, and close the State's disposal facility for lowlevel radioactive waste. The law has been amended several times since then. The law is currently codified as Chapter 402 of the Texas Health and Safety Code.

The 1981 law specified that "only low-level waste that is generated within the State of Texas may be accepted by a disposal site" (Section 402.052). In June 1993, Texas enacted compact legislation naming itself as host State for the disposal facility and naming Maine and Vermont as eligible members.

A NRC agreement State since 1963, Texas recently transferred responsibility for licensing and regulating the disposal facility from the Department of Health to the Natural Resource Conservation Commission. The Conservation Commission will evaluate the technical adequacy of the proposed site, but is not involved in the process by which the site was selected.

\subsection{Status}

Texas' siting process has gone through three iterations since its inception in 1982. The initial site selection process settled on several prospective locations in south central Texas. In response to political opposition, the legislature directed the Authority to screen State-owned land, which had been excluded by law from the initial siting process. Then, following a lawsuit by El Paso County against a prospective site on State-owned land in neighboring Hudspeth County, the legislature enacted a statute that designated a specific $400-\mathrm{mi}^{2}$ siting area in Hudspeth County, but farther from El Paso County.

After screening the area, the Board of Directors of the Authority selected the "Faskin Ranch" site in Hudspeth County as the preferred site for the disposal facility in May 1992. The Authority has completed site characterization, purchased the site, and submitted a license application for review.

\subsection{Legal and Regulatory Framework}

The Texas Low-Level Radioactive Waste Disposal Authority Act provided the Disposal Authority general guidance related to the process and criteria for siting the disposal facility, but gave the Authority considerable discretion in designing and implementing a siting program.

Section 402.08 of the law, "Studies for Site Selection," required the Authority to study the "areas of the State that are relatively more suitable than others for low-level waste disposal activities." The section also required the Authority to "consider" a number of common factors related to siting a disposal facility for low-level radioactive waste, including site access. One of the factors that the Authority was required to consider was any "criteria established by the (Texas Radiation Control) Agency for site selection" [Section 402.082(10)]. Beyond this, however, the 
law did not provide additional direction or constraints, or require that the siting process or siting criteria be codified by the Authority through a rulemaking process. Significantly, the law did not give the Authority the power of eminent domain to acquire land from unwilling landowners.

In 1985, in response to local opposition to the results of the site selection process, the law was amended to require the Authority to give preference to potential sites on State-owned land. As a result of the amended legislation, the Authority selected a site located on State-owned land in Hudspeth County in the western part of the State. Litigation and political opposition to the site by nearby El Paso County led to designation by the legislature in 1992 of an alternative siting area, also in Hudspeth County, but located farther from El Paso County.

\subsection{Siting Criteria}

The 1981 law did not provide detailed siting criteria, but did list a number of common factors that the Authority should consider in siting the facility, including geology, population density, and current land uses. Part 45 of the Texas Radiation Control Regulations, "Licensing Requirements for Near-Surface Disposal of Radioactive Waste," (October 1983) include performance objectives and technical requirements for disposal facilities that are similar to those contained in Federal regulations, $10 \mathrm{CFR}$ Part 61.

To expand upon the guidance in the regulations and to collect under one cover positions on site suitability, the staff of the Authority prepared the document Consideration for Site Selection in November 1982. The document also provided guidance to organizations preparing bids for the Authority for technical assistance in siting the facility. Based on these general requirements and standard technical guidance related to the State and Federal regulations, the document identified 24 specific siting criteria, 16 of which were considered exclusionary and eight of which were considered preferential.

\subsection{Site Selection Process}

The initial site selection process in Texas, conducted between 1983 and 1984, resulted in selection of a site near Tilden in McMullen County as the preferred site for detailed site characterization. The method of site selection was essentially a modified step-wise, top-down screening process. Because of the vastness and diversity of the State, it differed from phased screenings performed in other States. Regional-level screenings within areas that remained after a statewide exclusionary screening differed in emphasis from region to region based on the characteristics of the region.

The Authority contracted with various State agencies and universities, and Dames and Moore, to perform portions of the site selection process. The process was originally divided into three phases and was later expanded into five.

Phase 1-Statewide screening. The objective of the statewide screening phase was to limit the amount of land under consideration in the huge State. This could only be done by eliminating from consideration, in fairly broad-brush fashion, land area less likely to support 
suitable sites. Of the 24 criteria, nine were applied to eliminate areas from further consideration. These were:

- Areas where the tectonic process could significantly affect site performance

- Areas where surface geological processes could adversely affect site performance

- Areas including 100-year floodplains, coastal high hazard zones, or wetlands

- Areas including the recharge zone of aquifers

- Areas where recovery of significant natural resources could affect site performance

- Areas where future population growth could affect site performance

- Counties with population densities over 400 persons $/ \mathrm{mi}^{2}$

- Area within or adjacent to national or State parks, monuments, or wildlife management areas

- Areas not capable of being characterized, modeled, analyzed, and monitored.

Data and surrogate data providing a general measure of the criteria were applied to eliminate land from consideration. For example, under the criterion for "surface geological processes," the objective was to eliminate areas with dense lithostratigraphic units, complex rock structures from folding and/or faulting, and areas with fracture or jointed rock types. Information from several existing geological maps of the State provided information related to the criterion.

The dominant criterion in excluding land area proved to be recharge areas for aquifers. The exclusionary map for this criterion, shown at Figure 25, is similar to the composite results of the statewide screening (including designated physiographic regions from the next task) shown at Figure 26.

The second task of statewide screening was to identify distinct physiographic regions among the land that remained under consideration and to compare the regions. Fifteen potential regions comprising approximately $35,000 \mathrm{mi}^{2}$ in 105 counties were identified. Maps were prepared for each of the regions illustrating land with characteristics more favorable for siting and land with characteristics less favorable for siting. Most of the information on these illustrations was compiled from the Geologic Atlas of Texas at 1:250,000 scale. Figure 27 shows the resulting map for one of the areas, the Abilene-Haskell Plains.

The purpose of these regional maps was twofold: (a) to further eliminate the amount of area under consideration, and (b) to allow investigators to decide in a qualitative manner, based on the illustrations, which of the areas should undergo a more detailed screening at the regional 


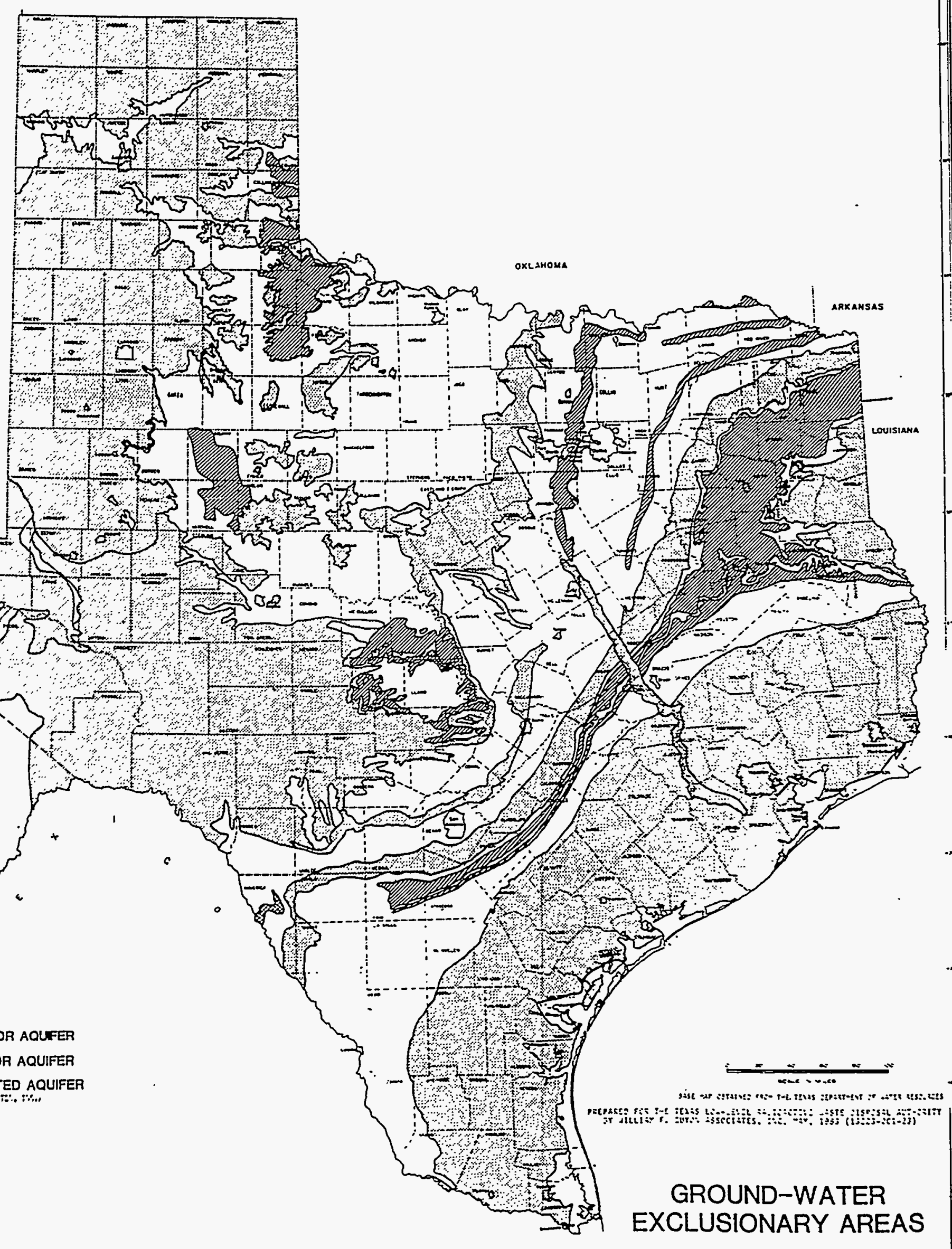

areas. 


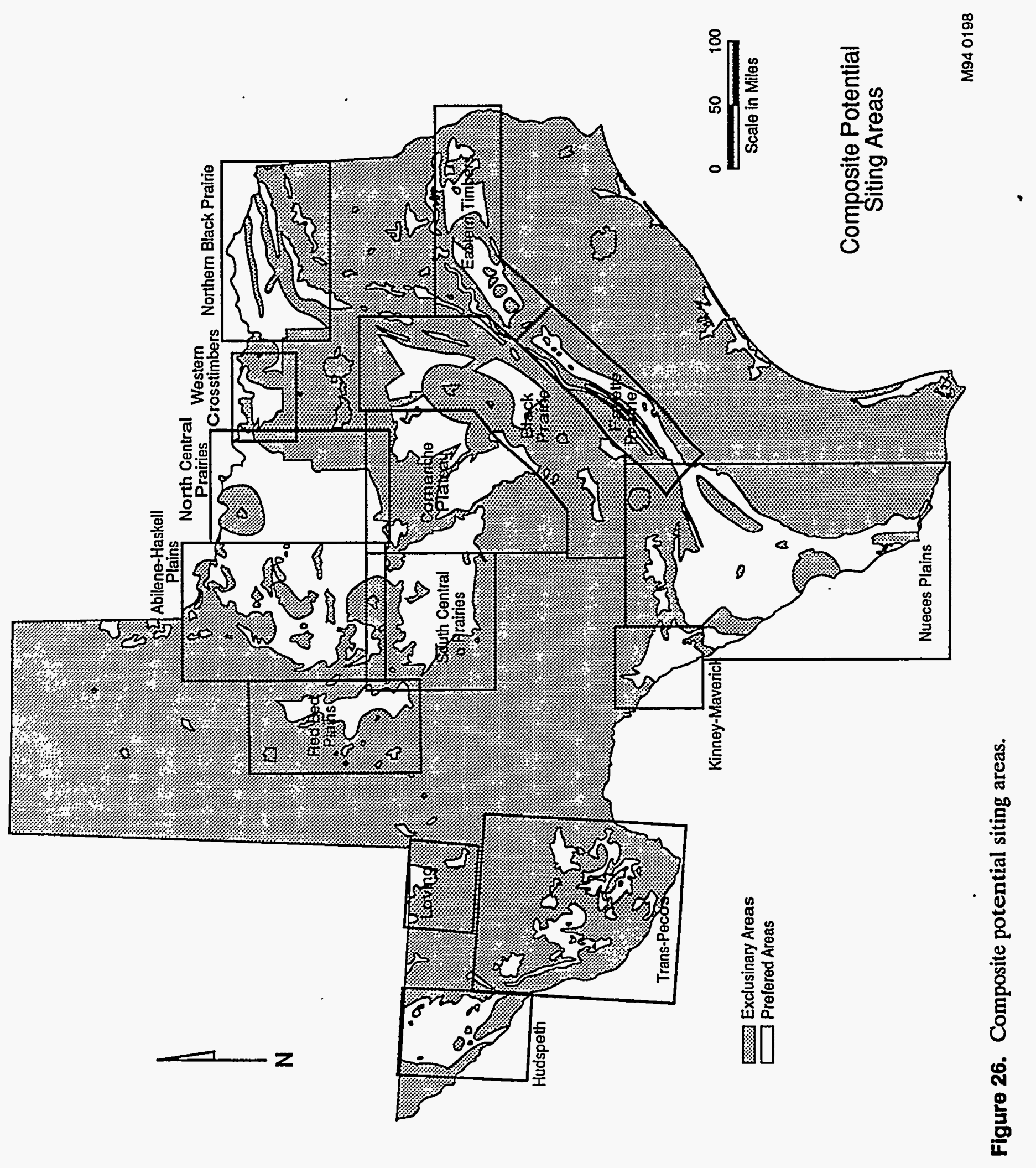




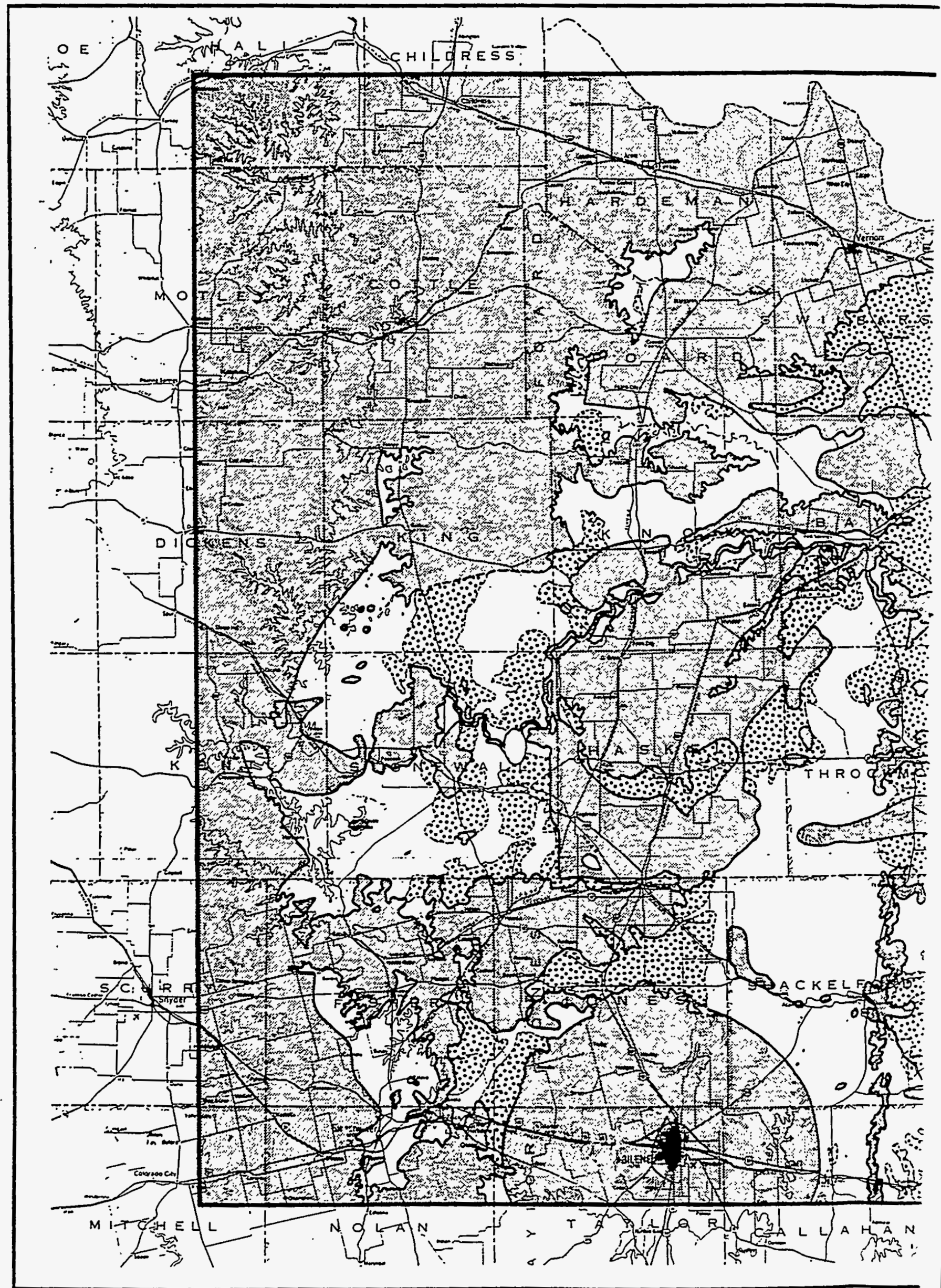

Figure 27. Abilene-Haskell plains composite regional screening. 


\title{
LEGEND
}

EXCLUSIONARY (TASK 1) PLUS

REGIONAL SCREENING (TASK 2)

. AREAS OF PREFERRED SOIL CONDITIONS

SCALE IN MILES

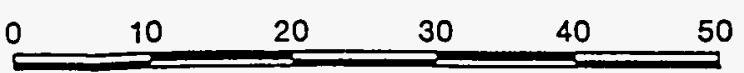

PAEPARED FOR THE TEXAS LOW-LEVEL RADIOACTIVE WASTE DISPOSAL AUTHORITY BY DAMES \& MOORE MAY, $1083(13223-001-23)$

\author{
ABILENE-HASKELL PLAINS \\ COMPOSITE REGIONAL SCREENING
}


level. Of the 15, eight areas were selected as "preferred siting areas" for regional screening. The eight areas were:

1. Hudspeth

2. Abilene-Haskill Plains

3. Red Bed Plains

4. Northern Black Prairie

5. Western Crosstimbers

6. Nueces Plains

7. Black Prairie

8. North Central Prairies.

Phase 2-Regional screening and site identification. The objective of Phase 2 was to identify two or more sites to undergo preliminary characterization studies. After this work, one would be designated by the Board of Directors of the Authority as a "Prime site." Phase 2 included three tasks.

Task 1-In Task 1, composite maps were prepared showing the more favorable and less favorable land within each of the eight regions considering geological characteristics and proximity to transportation corridors. Because of the diversity of the regions, geological characteristics considered favorable or unfavorable for siting differed from region to region. Rather than establishing a preconceived set of geological conditions against which to evaluate land for inclusion or exclusion, the characteristics of the land area in each region were evaluated in a more qualitative manner. This had the effect of distinguishing geological characteristics that were "relatively" favorable within a specific region, but required deferral of intercomparison of land between regions until a later step. Screening for transportation access at this stage involved mapping portions of the more favorable areas from the geological evaluation that were within 5-mi of non-load-limited roads.

Task 2-The objective of Task 2 was to identify specific "tracts" of about 300 acres with relatively uniform characteristics from the more favorable land from Task 1 . This was done in a qualitative, but systematic, manner using USGS quadrangle maps $(1: 24,000)$ and field reconnaissance. Discontinuities within a land area due to the presence of one or more disqualifying characteristics caused potential tracts to be split into more than one tract, or to be eliminated if the remaining area was below a minimum size of 200 acres. Composite sketch maps of each tract were prepared based on the evaluation. This exercise resulted in about 280 distinct tracts of land in six of the eight regions under study.

To identify specific site locations within the tracts, the Disposal Authority continued with the qualitative top-down screening exercise, while soliciting landowners to volunteer parcels. To 
screen further, the Authority applied more stringent thresholds to the already existing criteria, and included, where available, local information and data. For example, where documentation was available to show that groundwater was less than $100 \mathrm{ft}$ below the surface, the tract was eliminated. Tracts were also eliminated that were in greater proximity to some undesired feature (surface water, for example), even though the tract itself might not include the feature.

Because the Disposal Authority lacked the power of eminent domain, and all surface and mineral rights (often separately owned in Texas) were required for the disposal site, the Disposal Authority also decided to identify land that might be available for purchase within or near the 280 tracts of land. These efforts, which were conducted through real estate brokers, began in May 1983. By February 1985, 10 sites had been identified as potentially available for acquisition by the Authority.

At the end of this phase, 57 potentially suitable sites had been identified, including 10 that were potentially available for purchase.

Task 3-The next step was to devise a method to evaluate the 57 sites against each other. A weighting-scoring system was developed as a means to compare the sites in quantitative fashion. While the method resembled weighting-scoring methods used by other States, it differed in its application. The exercise was meant only to provide guidance to members of the Authority, who ultimately were responsible for selecting sites for characterization by a vote of the members.

For purposes of scoring and weighting, the Authority identified 17 evaluation "issues," which were siting considerations that best lent themselves to comparison of sites. Each evaluation issue was subdivided into factors, or subissues. For example, under the evaluation issue, "Historical, Archeological and Cultural Features," there were three factors: (a) distance to the nearest active school or church, (b) distance to the nearest historic site or cemetery, and (c) distance to the nearest archaeological site. Subject specialists were used to score each site with respect to each of the factors. A panel of individuals with diverse backgrounds assigned numerical weights to each of the factors, based on their view of its importance relative to the others. The numerical rating for each site was the sum of the scores of the site under the factors multiplied by the respective weight of the factors.

In reviewing the results of the weighting-scoring exercise, the Authority noted that the results often were similar for sites within the same region, since they shared the same general characteristics. Because of this, the Authority decided to select sites for further evaluation from three regions where sites consistently ranked higher, even though a few sites in the other two regions were also rated relatively high. Also included among sites recommended for further evaluation were five sites potentially available for purchase. Of these, two were located in Hudspeth County, outside the three areas in which all the other recommended sites were located. A total of 26 sites were recommended to undergo preliminary characterization studies in Phase III (see Table 7).

Phase 3-Preliminary site characterization. Although 26 sites had been recommended to undergo field investigations, without the power of eminent domain the Authority had no way to gain access to the sites without permission of the owners. After attempting to gain access, the 
Table 7. Recommended sites.

\begin{tabular}{|c|c|c|c|c|}
\hline Site no. & USGS quad & County & $\begin{array}{l}\text { Environmental } \\
\text { rank }\end{array}$ & $\begin{array}{c}\text { Engineering/ } \\
\text { economic } \\
\text { rank }\end{array}$ \\
\hline \multicolumn{5}{|c|}{ Nueces Plains } \\
\hline NP-E1B & Leal & Atascosa & 25 & 3 \\
\hline NP-E8A & Hindes & LaSalle & 10 & $16 / 17$ \\
\hline NP-E15A & Los Angeles & LaSalle & 12 & $19 / 20$ \\
\hline NP-EI5B & Los Angeles & LaSalle & 20 & 7 \\
\hline NP-E15E & Los Angeles & LaSalle & 18 & $28 / 29$ \\
\hline NP-E15F & Los Angeles & LaSalle & 2 & 30 \\
\hline NP-E16A & Cotulla & LaSalle & 5 & $28 / 29$ \\
\hline NP-W5A & Beef Hollow Creek & Zavala & 16 & 5 \\
\hline NP-W8A & Carrizo Springs NW & Zavala & 1 & 8 \\
\hline NP-W8D & Carrizo Springs NW & Dimmit & 6 & 2 \\
\hline NP-W17A & San Lorenzo Creek & Dimmit & 4 & 40 \\
\hline \multicolumn{5}{|c|}{ Red Bed Plains } \\
\hline RBP-3A & Westbrook & Mitchell & 17 & 36 \\
\hline $\mathrm{RBP}-4 \mathrm{~A}$ & Iatan & Mitchell & 28 & 50 \\
\hline RBP-14B & Five Mile Creek & Borden & 31 & 10 \\
\hline RBP-14D & Five Mile Creek & Borden & 32 & 9 \\
\hline RBP-21B & Cottonwood Creek & Garza & 13 & 38 \\
\hline RBP-24A & Verbena & Garza & 11 & 43 \\
\hline RBP-27C & Kalgary & Crosby & 21 & 49 \\
\hline RBP-27D & Kalgary & Garza & 14 & 51 \\
\hline \multicolumn{5}{|c|}{ Abilene-Haskell Plains } \\
\hline AHP-E8A & Irby & Haskell & 37 & 39 \\
\hline AHP-E8B & Irby & Haskell & 34 & 42 \\
\hline \multicolumn{5}{|c|}{ Potentially available sites } \\
\hline NP-E11F & Pertle Creek & McMullen & 3 & 56 \\
\hline NP-F9A & Asherton & Dimmit & 7 & 1 \\
\hline NP-W18D & Encinal SE & LaSalle & 8 & $19 / 20$ \\
\hline HU-1A & Red Hills & Hudspeth & 15 & $16 / 17$ \\
\hline HU-1B & Red Hills & Hudspeth & 9 & 53 \\
\hline
\end{tabular}


Authority decided to proceed with precharacterization work at the five sites on the recommended list that were potentially available for purchase. The location of these sites were:

- Northwest McMullen County (south Texas)

- Near Asherton in Dimmit County (south Texas)

- Southwest of Dell City in Hudspeth County (far west Texas)

- Ten miles south of the HU-1A site in Hudspeth County (far west Texas)

- Near Encinal in LaSalle County (south Texas).

Following preliminary characterization studies, the Authority considered each of the sites potentially suitable for a disposal facility. In August 1984, the Board of Directors of the Authority designated two sites, one in northwest McMullen County and one in Dimmit County, for further study.

Phase 4-Legislative redirection of the siting process: evaluation of state-owned lands. Following the selection of two sites for characterization, increased opposition at these two locations led the legislature to amend the State law to redirect the siting effort in order to give preference to State-owned lands. Section 3.07A(a) provided that,

If funds are specifically appropriated to the authority to search for and acquire a disposal site on State-owned land dedicated to the permanent school fund or the permanent university fund, the authority shall give preference to any suitable site on that land over other equally suitable sites in selecting a disposal site under Section 3.07 of this Act.

The amendments also included a prohibition against siting a facility within $20 \mathrm{mi}$ of certain types of reservoirs. This prohibition eliminated the preferred sites in McMullen and Dimmit Counties.

Evaluation of State-owned land began in February 1985. The study was divided into three tasks.

Task 1-Under the first task, the Authority acquired information from the General Land Office on the amount of State-owned land in each county. Of 2,900,337 acres of Stateowned land in 168 counties, 2,114,130 acres in 23 counties were controlled by the University of Texas system. Because the Authority did not yet know the exact location of the land in each county, county units were used at this stage in the screening process. Counties with less than 320 contiguous acres and counties located entirely within excluded areas from the statewide screening were eliminated from consideration. In remote counties where the location of the State-owned land was ascertained, those whose State-owned land was inaccessible by public road or under long-term mineral lease obligations were also excluded. This left land in 16 counties under consideration. 
In the next step, the specific location of land in the 16 counties was compared against the location of the potential siting areas from the statewide screening. At this stage, virtually all the State-owned land within potentially suitable siting areas was located in eight counties in far west Texas, and $78 \%$ of the land was located in Hudspeth County (see Figure 28). A few very small tracts of land in locations other than far west Texas were eliminated from consideration after further investigation revealed that they were either in a flood plain, near a proposed reservoir, under long-term oil and gas leases, or burdened with other shortcomings for siting.

Task 2-The remaining State-owned land was divided into three regions for purposes of map preparation. Each region was screened individually, based upon information and data available for each region. At this level, screening was performed at the scale of 1:250,000. In a manner similar to the statewide study, composite maps were prepared by hand from reference maps and information. As in the initial regional screening, evaluation of statewide land at the regional level was limited to exclusionary screening. That is, a weighting-scoring method for applying preference criteria as "shades of grey" (e.g., New York) was not attempted. Based on a number of criteria and characteristics of the region, land was either shaded on the maps as excluded or left unshaded as not excluded. In each region, characteristics and geologic formations considered adverse to siting were excluded regardless of whether or not data on similar characteristics in other regions were known to exist.

Regional exclusionary screening reduced the amount of land still under consideration to 427,000 acres, with land remaining in six of the eight western counties. At this stage, the process shifted from top-down exclusionary screening to evaluation of specific State-owned tracts using features identified on USGS topographical maps at scales of 1:24,000 and 1:62,500. These features include surface topography, slope, nonconforming land use (e.g., quarries and landfills), access to roads, surface water bodies, marshes, communities, schools, churches, parks, recreational areas, and cemeteries. This composite mapping exercise resulted in 107 specific tracts.

With conclusion of this step, the Authority essentially exhausted all of the mapped data available for screening and site evaluation, and turned to air reconnaissance and onsite visits of selected sites. The objective of this phase of the project was to employ professional judgement to elect, from the 107 tracts, a smaller number of potential sites that could be subjected to a more quantitative ranking system. Following a series of site visits and technical meetings, the staff of the Authority selected 20 sites for further evaluation.

The 20 sites were ranked using a weighting-scoring method similar to that used in the initial siting study (see Phase II, Task 3, above). Because of the subjective nature of scoring sites against the various criteria, and the subjectivity involved in weighting the criteria themselves, the results of the ranking process were intended to be advisory, rather than controlling. Moreover, in the vast expanse of western Texas, the Authority recognized that important distinctions among prospective sites, where they existed, could only be made through onsite reconnaissance and field investigations. Tables 8 and 9 provide the results of the scoring exercise. In the tables, the Fort Hancock site, which was finally selected, is site NTP-S34.

Task 3-The final decision on which of the 20 sites would undergo preliminary site evaluations was made by the Authority's technical staff following extensive consultation with the 


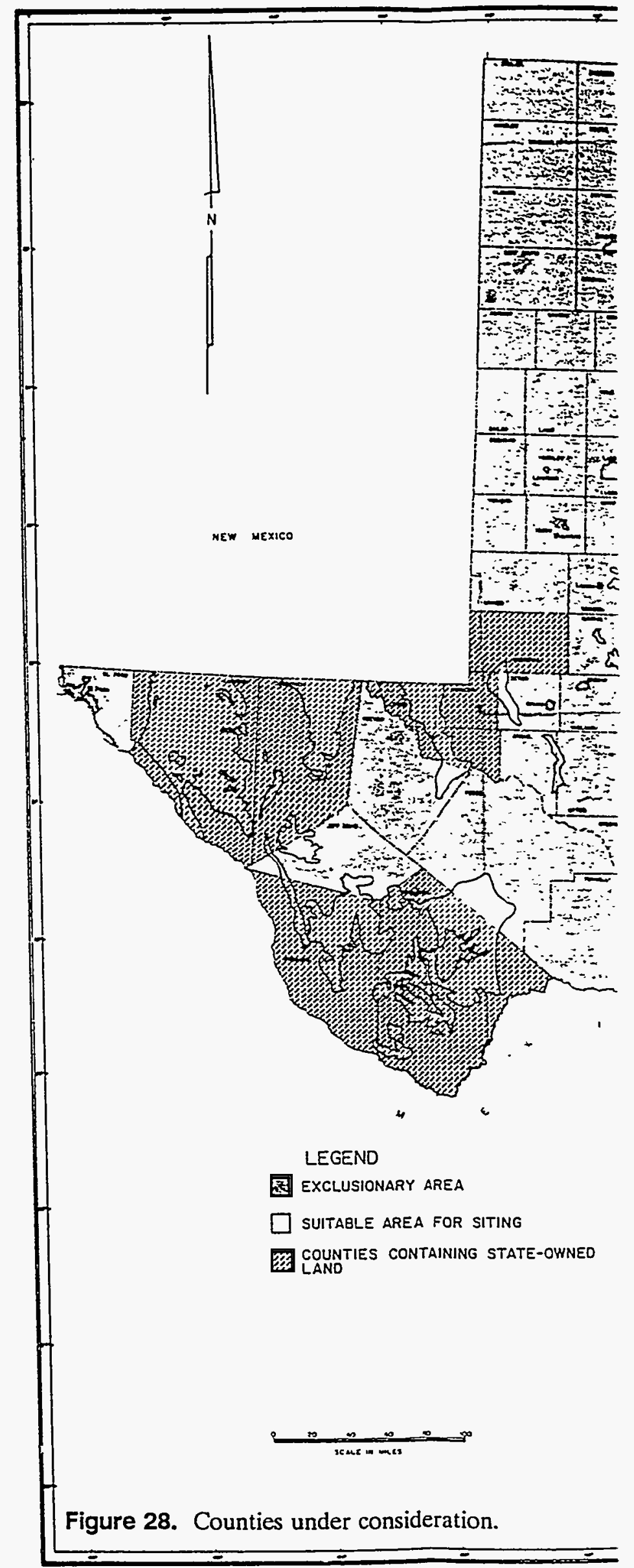




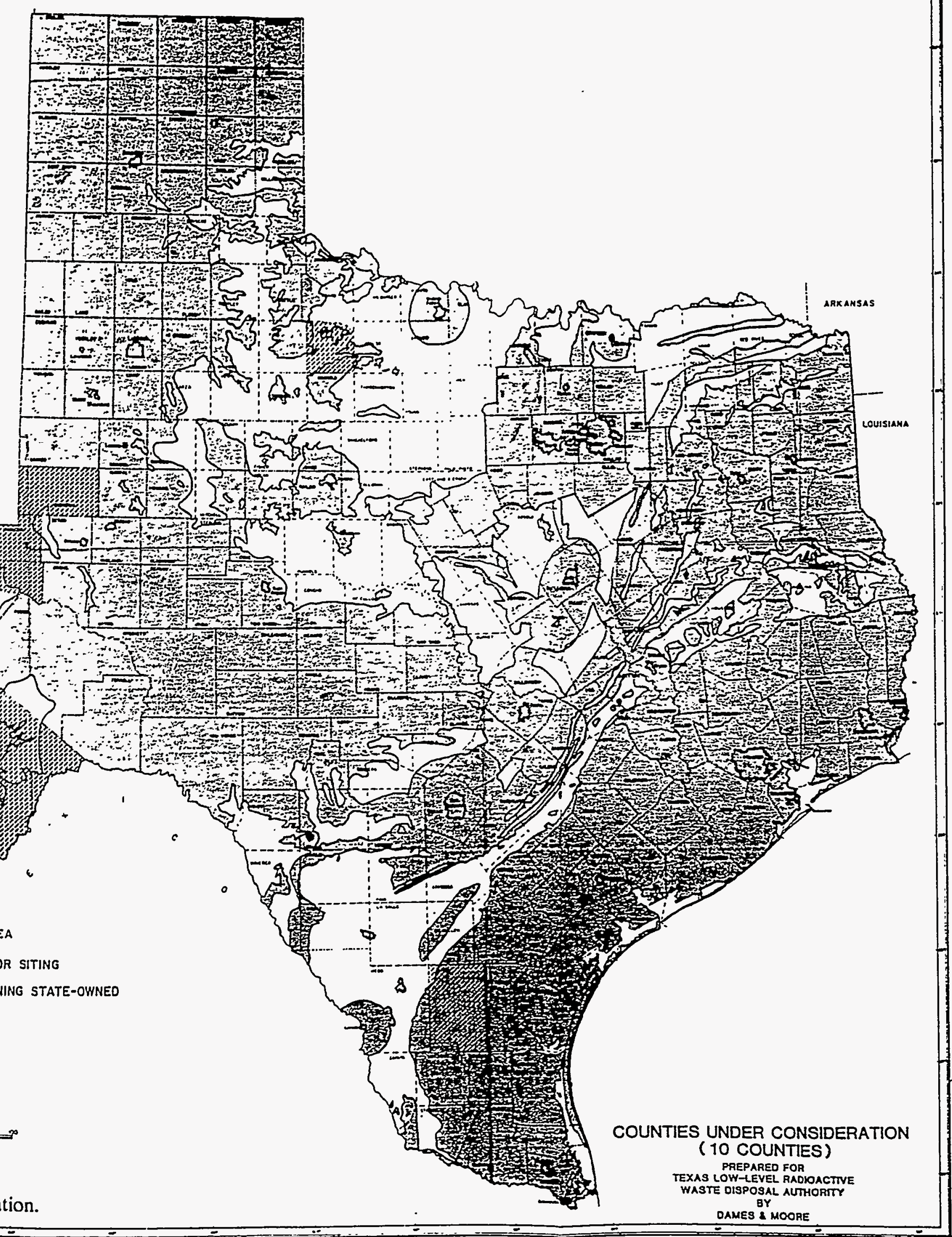


Table 8. Environmental ranking.

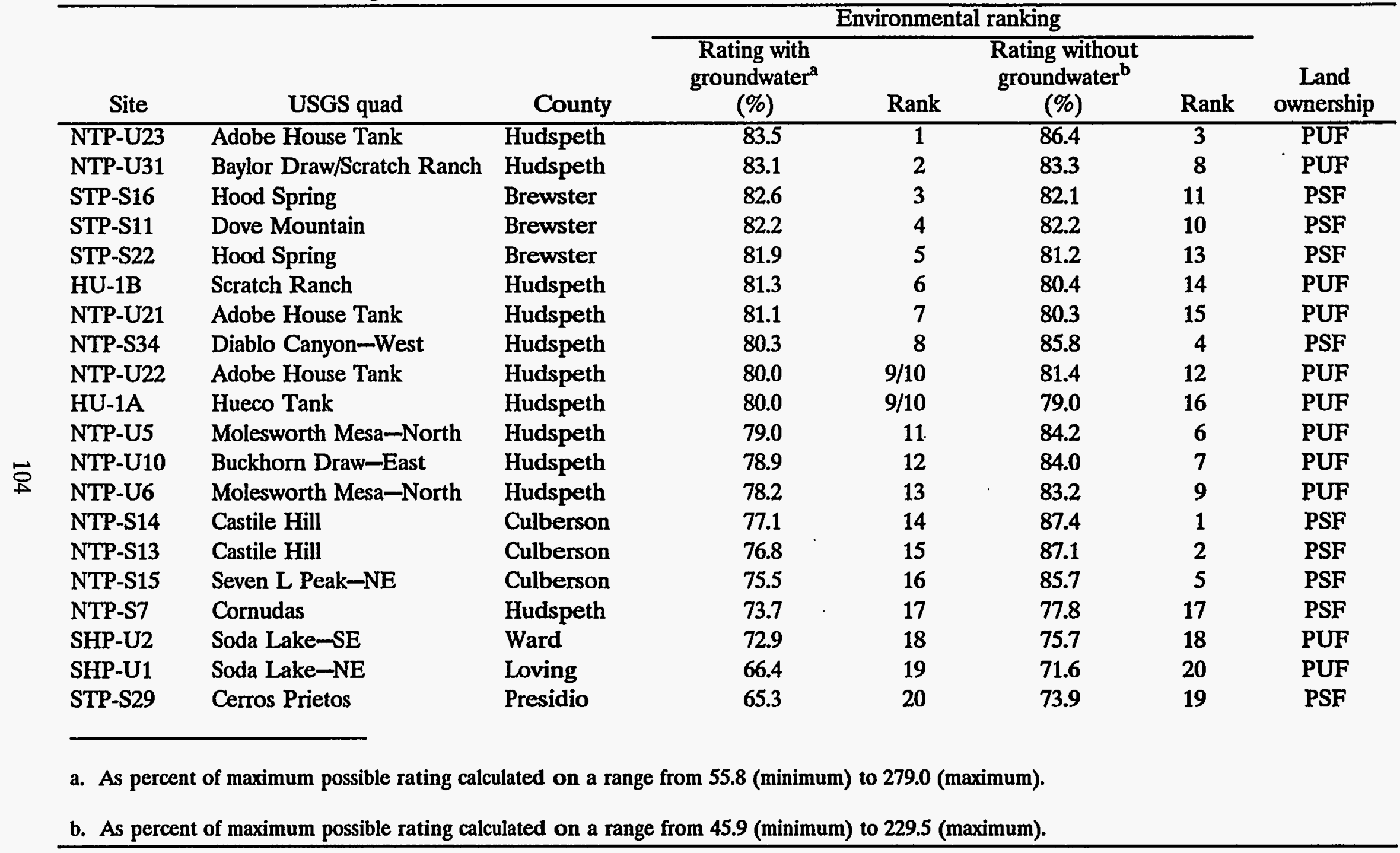


Table 9. Engineering and economic ranking.

\begin{tabular}{|c|c|c|c|c|c|}
\hline \multirow[b]{2}{*}{ Site } & \multirow[b]{2}{*}{ USGS quad } & \multirow[b]{2}{*}{ County } & \multicolumn{2}{|c|}{$\begin{array}{c}\text { Engineering/economic } \\
\text { ranking }\end{array}$} & \multirow[b]{2}{*}{$\begin{array}{c}\text { Land } \\
\text { ownershi }\end{array}$} \\
\hline & & & $\begin{array}{c}\text { Rating }^{\mathrm{a}} \\
\%\end{array}$ & Rank & \\
\hline NTP-U22 & Adobe House Tank & Hudspeth & 76.4 & $1 / 2$ & PUF \\
\hline NTP-U21 & Adobe House Tank & Hudspeth & 76.4 & $1 / 2$ & PUF \\
\hline NTP-U23 & Adobe House Tank & Hudspeth & 74.4 & 3 & PUF \\
\hline SHP-U1 & Soda Lake-NE & Loving & 74.3 & 4 & PUF \\
\hline NTP-U31 & $\begin{array}{l}\text { Baylor Draw/ } \\
\text { Scratch Ranch }\end{array}$ & Hudspeth & 72.7 & 5 & PUF \\
\hline HU-1A & Hueco Tank & Hudspeth & 72.6 & 6 & PUF \\
\hline NTP-U10 & $\begin{array}{l}\text { Buckhorn } \\
\text { Draw-East }\end{array}$ & Hudspeth & 72.2 & 7 & PUF \\
\hline SHP-U2 & Soda Lake $-S E$ & Ward & 71.4 & 8 & PUF \\
\hline NTP-S34 & $\begin{array}{l}\text { Diablo } \\
\text { Canyon-West }\end{array}$ & Hudspeth & 70.0 & 9 & PSF \\
\hline NTP-S13 & Castile Hill & Culberson & 69.5 & 10 & PSF \\
\hline NTP-S7 & Cornudas & Hudspeth & 66.8 & $\cdot 11$ & PSF \\
\hline STP-S16 & Hood Spring & Brewster & 62.2 & $12 / 13 / 14$ & PSF \\
\hline STP-S11 & Dove Mountain & Brewster & 62.2 & $12 / 13 / 14$ & PSF \\
\hline STP-S22 & Hood Spring & Brewster & 62.2 & $12 / 13 / 14$ & PSF \\
\hline NTP-U6 & $\begin{array}{l}\text { Molesworth } \\
\text { Mesa-North }\end{array}$ & Hudspeth & 57.1 & $15 / 16$ & PUF \\
\hline STP-S29 & Cerros Prietos & Presidio & 57.1 & $15 / 16$ & PSF \\
\hline NTP-S15 & Seven L Peak-NE & Culberson & 56.6 & 17 & PSF \\
\hline HU-1B & Scratch Ranch & Hudspeth & 56.1 & $18 / 19$ & PUF \\
\hline NTP-U5 & $\begin{array}{l}\text { Molesworth } \\
\text { Mesa-North }\end{array}$ & Hudspeth & 56.1 & $18 / 19$ & PUF \\
\hline NTP-S14 & Castile Hill & Culberson & 55.7 & 20 & PSF \\
\hline
\end{tabular}

a. As percent of maximum possible rating calculated on a range from 31.9 (minimum) to $\mathbf{1 5 9 . 5}$ (maximum). 
technical specialists involved in the project. Because of the technical similarity of the sites, depth to bedrock and transportation access became significant factors in the selection.

Seven sites underwent onsite studies. Four of the seven sites were not recommended because of shallow bedrock, proximity to faults, relatively high groundwater, unstable sands, or proximity to oil and gas fields. Based on the results of the onsite studies, three sites, each located in Hudspeth County, were recommended for further onsite investigation. According to an October 1985 report issued by the Authority:

(The three sites) contain favorable characteristics and warrant further consideration by the Authority. [Two of the sites, including the Fort Hancock site] have geologically favorable characteristics because of the probable uniformity of underlying formations, whereas (another of the three recommended sites) possesses more favorable characteristics in terms of groundwater.

Following preliminary studies, one of the sites was removed from consideration because of the potential for large flood flows of short duration and the potential for recharge to the groundwater. In November 1986, the Board of Directors of the Authority selected two sites for continued study, the Fort Hancock site and another site, the Diablo Plateau site, located farther northeast in the county. The Diablo Plateau site had been identified during the initial statewide siting process. A risk assessment by the Authority based on site conditions showed no significant differences between the two sites. The Fort Hancock site was selected because of its greater depth of fill and easier transportation access.

In February 1987, the staff of the Authority was prepared to request that the Board designate the Fort Hancock site as the most suitable. At that time, El Paso County was granted an injunction against the Authority to prevent the Board from taking any action to designate the site as the preferred site. However, after almost a year of litigation, the Authority decided to begin characterization of the site prior to its formal designation as the preferred site. Following substantial completion of site characterization, on September 11, 1989, the Board of Directors of the Authority designated the Fort Hancock location as the proposed site for waste disposal as required by Chapter 402 of the Health and Safety Code.

Phase 5-Legislative redirection of the siting process: statutory designation of a siting area. The district court's ruling on the Fort Hancock site voided the Authority's site selection process and determined that the Authority acted beyond the scope of its power in choosing the Fort Hancock location for the site. The court said the Authority wrongly applied a State law that requires "preference should be given to sites on State-owned lands," by interpreting the law as a mandate that the site be located on State land. The court said this would give an inordinate weight to State land and would cause potentially suitable sites on non-State-owned land to be disregarded.

The court's decision and continued political opposition by officials from El Paso County led to designation by the legislature of a specific siting area. With support from the Authority, House Bill 2665 was introduced designating the Fort Hancock site by law as the preferred site. In response to fervent opposition to the proposed legislation by opponents of the Fort Hancock site and consultation with residents of Hudspeth County, the Authority proposed amending the bill to 
designate a $400-\mathrm{mi}^{2}$ siting area in the southeastern portion of the county. The area had been identified as potentially suitable in the initial statewide screening and also was less objectionable to opponents in El Paso County. The new law provided that:

Not withstanding any other law or other provision of this chapter, the board shall select as the disposal site, a site: (1) within Hudspeth County, Texas, and (2) circumscribed on the north by 31 degrees north latitude, $15^{\prime}$ and $00^{\prime \prime}$; on the south by 31 degrees north latitude, $00^{\prime}$ and $00^{\prime \prime}$; on the east by 105 degrees longitude, $00^{\prime}$ and $00^{\prime \prime}$; and on the west by 105 degrees longitude, 22' and 30 .

The law, which also granted the Authority the power of eminent domain, was the first and, so far, only instance of State legislation designating a specific study area for a low-level radioactive waste disposal site.

\subsection{Final Site Selection}

The Authority began investigations in the preferred area in June 1991. Five tracts of land were identified as potentially suitable. An analysis of land availability was conducted simultaneously with the technical investigations. The result of the study was selection of the Faskin Ranch site. Permission to enter and inspect the ranch was obtained from the owners, and preliminary investigations of the ranch were conducted in the fall of 1991. In March 1992, a license application was submitted for the site. 


\section{EVALUATION OF APPROACHES TO SITE SELECTION}

In this section, principal differences among State site selection processes are discussed, beginning with the level of specificity of State legislation and regulations governing the projects, and the organizational approaches to the projects. The most notable difference among State siting criteria has been in the application of nontechnical criteria, such as land use considerations and public acceptability. The use by most States of "top-down screenings" as a site selection strategy, and issues involved in such screenings, are discussed in some detail. Principal issues have involved whether or at what stages to employ quantitative or qualitative techniques, considerations in delineating the borders of screening units, and the implications of excluding land from further consideration based on general-level data.

\subsection{Legal and Regulatory Framework}

The States have differed in the extent to which laws and regulations were used to prescribe procedural steps toward site development. Connecticut and New York established a "certification" step, whereby a State agency would ascertain that the site location or the facility design met State requirements, apart from review of the license application. New York law also required the siting organization to propose a waste disposal technology or "method" at the same time a site location was proposed. Connecticut law preempted the siting organization's consideration of alternative siting strategies by prescribing a phased top-down screening process. By requiring county or municipality approval of a proposed site, Illinois law effectively foreclosed the use of a top-down mapping approach that would have been blind to jurisdictional borders.

The site selection process in Texas was redirected twice through legislation, first to require reconsideration of State-owned land, and second to designate a specific study area for the site. After selection of a preferred site, Illinois established a commission with authority to approve or disapprove the site even before completion of the technical review of the license application. Maine law required a $60 \%$ statewide voter approval of any site location.

States also differed in the degree to which they codified additional site requirements in the form of statutes and regulations. Basic performance objectives and technical requirements for proposed low-level radioactive waste disposal sites were already in place, of course, in Federal regulations and their agreement State equivalents (see Section 1.2). Encoding additional site criteria in laws or regulations can provide the siting organization a defensible starting point for selecting more specific screening factors and data sets. A disadvantage of specifying site requirements in new laws and regulations is that it can preempt decisions and reduce the ability of the siting organization to incorporate suggestions from the public at the local level.

With a few variations, California, Maine, Nebraska, and Texas used the preexisting regulatory requirements as the basis for developing more specific criteria through administrative processes. North Carolina law does not specify additional site requirements, but regulations issued by the State require the siting organization to "consider" a number of other factors, including "use of large land holdings by utilities or other industries, including land adjacent to nuclear power plants." The Illinois statute espoused some general objectives, like requiring the site to be located so that public health, safety, and welfare will be protected. Its most notable 
addition to the preexisting site regulations, however, were stringent provisions for approval of the site by the county or municipality in which it was located.

Of all the State laws, Michigan's stands alone in prescribing a long list of site requirements additional to those already codified in Federal and State regulations. Some of the new requirements demonstrated the legislature's confidence in the tools of scientific measurement: the site had to be at least $1 \mathrm{mi}$ from locations where tectonic movement has occurred "within the 10,000 years preceding the effective date of this act." Others showed an uneasiness about leaving technical details to the judgment of those implementing the process: the statute, itself, required the site to have "six or more meters of soil with a maximum permeability of 1.0 times 10 to the minus $6 \mathrm{~cm} / \mathrm{sec}$ at all points below and lateral to the bottommost portions of the leak detection system of the disposal units," or an area that provides equivalent protection. Independent consultants to the Midwest compact commission and to the Michigan Low-Level Radioactive Waste Authority concluded that it was unlikely any site would be able to meet the statutory requirements.

While Connecticut and New York statutes did not include additional criteria, the laws authorized State agencies to promulgate new requirements in the form of regulations. In both States, the agencies decided to exercise the authority by issuing detailed criteria.

\subsection{Siting Criteria}

The previous section discusses the extent to which States prescribed site requirements in the form of statutes and regulations. Beyond this, a meaningful comparison of the technical siting criteria-those related to the ability of the site to isolate the waste-can only be performed at the steps in the siting process at which the requirements are applied. This is because the published requirements are often worded in a manner that requires additional elaboration or interpretation before the requirements can be applied in a site screening exercise or an onsite investigation.

Several examples illustrate the difficulty in comparing technical siting criteria. At the highest level of abstraction, a published "siting criterion" may simply require that facility be located "so that public health, safety and welfare will be protected" (Illinois law). This, of course, encompasses a range of desirable qualities and requires some interpretation before practical application. The next level down, typical of published State siting criteria, addresses a narrower range of desirable qualities, but still does not provide a test with which to determine whether the condition has been met. For example, a site "must provide sufficient depth to the water table so that water intrusion does not occur" (10 CFR Part 61 and State equivalents). As applied in a site screening or site evaluation process, site requirements must be quite specific and prescribe the particular data set with which each requirement is to be measured. Often, these decisions are made at the level of implementation by staff and technical specialists of the siting organization. A meaningful comparison of siting requirements at this level is beyond the resources available for this report.

Because of the vast differences in the geophysical characteristics of the various States, even comparing technical site requirements at the level of application has limited value. Within a study area, such as a State, the objective is to select site locations that are favorable, relative to other land within the study area. California's statutory requirement that areas be excluded from 
consideration if they have more than 10 in. of rainfall, of course, does not represent a technical finding that more than that amount of rainfall would make a site location unsuitable for disposal of low-level radioactive waste. Rather, it was intended as a pragmatic way to focus the site search on a smaller study area with conditions relatively favorable, when compared to other areas in the same State.

Another hazard in attempting to compare published technical site suitability requirements is that the absence of an explicit, published criterion in a State relating to a particular characteristic does not necessarily mean that the characteristic was not considered. This is because an evaluation of the ability of the proposed facility to meet the basic "performance objectives" (see Section 1.2) requires consideration of a wide range of technical factors, whether or not these are ever specified as "siting criteria." For example, the objective that a site "protect the general population from releases of radioactivity" (10 CFR Part 61.41) encompasses considerations related to geology, surface and subsurface hydrology, meteorology, facility design, demographics, and many other areas.

Apart from the technical site requirements, however, notable differences among the States can be observed in their application of nontechnical criteria (e.g., land use considerations and public acceptability). Criteria in all the States required exclusion or avoidance of some types of land uses, such as State and Federal parks and recreation areas, regardless of the geophysical characteristics of these areas. Nonagricultural land was preferred in California, Connecticut, Illinois, and New York for reasons unrelated to site performance. At first, Texas law required the siting organization to avoid State-owned land, then later required such land to be reconsidered.

The widest variation among States has been in the extent to which public acceptance and land availability have been factored in to their site selection processes. As described elsewhere in this report, Connecticut's site selection process included procedures to ensure that the level of public or political acceptance was not considered at all. At the other extreme, Illinois and Maine required local public approval as a matter of law, by vote of the town or county board or by town referendum, respectively. Nebraska law required the siting organization to "make every effort" to site where community consent for the facility is evident. In that State and in Illinois, counties were not even included in the screening process if they chose not to be. The change in Texas' law expressing a preference for State-owned land was also in response to growing recognition that public support is important in successfully siting the proposed facility. In New York, ironically, the State is prohibited by law from siting the low-level radioactive waste disposal facility at the closed West Valley Nuclear Services Center site, near the only community that has expressed interest publicly in hosting the facility.

Similarly, the availability of land for purchase has also been a consideration related to public acceptability. Condemnation proceedings by governments to seize land for other kinds of waste management facilities have often resulted in community opposition. In general, land availability as a site selection factor has occurred near the end of the screening process, when there is little data left with which to compare the areas or sites that remain under consideration. With little else to distinguish among potential site locations, it makes sense to explore which land parcels within these remaining areas might be available for purchase. The availability of land for purchase was considered near the end of the siting processes in California, Nebraska, and Texas, as well as in Illinois, which had the power of eminent domain. In Connecticut, where land 
availability was not a factor in site selection, site investigators were physically prohibited from entering the chosen sites by landowners and their supporters.

\subsection{Site Selection Processes}

Federal law requires States to dispose of low-level radioactive waste, but does not tell the States how to select site locations for the new disposal facilities. The first decision faced by siting officials is the organizational approach to the problem. Once an organizational infrastructure is chosen, a site selection strategy must be developed.

\subsubsection{Governmental Approaches to Site Selection}

State organizational approaches differed in the degree of government involvement in site selection decisions. (Comparative organizational approaches will be the subject of another report in this series.) Although any proposed disposal facility for low-level radioactive waste must meet basic regulatory site requirements, most of the States have also reserved varying degrees of involvement in decisions related to site location. Primary responsibility for candidate site selection is depicted in Table 10.

Even among the States that vested responsibility for site selection in State organizations, there has been wide variation in the manner and degree to which intermediate decisions have been delegated to contracting organizations in the private sector. In Texas, for example, various technical contractors were employed as an extension of staff. Contractors assisted with different phases of site screening, but were rarely delegated responsibility for siting decisions. In North Carolina, which used an "integrating contractor" approach (single contractor to site, develop, and

Table 10. State organizational approaches to site selection.

\begin{tabular}{ll}
\hline $\begin{array}{l}\text { California } \\
\text { Connecticut }\end{array}$ & $\begin{array}{l}\text { Private sector company via contract with State agency } \\
\text { Illinois }\end{array}$ \\
Existing State waste management agency \\
Maine & $\begin{array}{l}\text { Existing State regulatory agency; after site selection, an adjudicatory } \\
\text { panel was created to approve or disapprove the site }\end{array}$ \\
Michigan & New quasi-State agency \\
Nebraska & New semi-autonomous organization within existing State agency \\
New York & Private sector company via contract with compact commission \\
North Carolina & New quasi-State agency \\
Texas & New quasi-State agency \\
& New quasi-State agency
\end{tabular}


operate the site), responsibility for numerous intermediate decisions and recommendations was delegated to the company, subject to oversight by the board and staff of the State siting organization. Similarly, in Connecticut and Maine, single siting contractors were delegated wide latitude in making intermediate technical decisions related to site screening, subject to employer oversight.

The two jurisdictions that eschewed the governmental approach to site selection did so very early in the era of State responsibility for disposal of low-level radioactive waste. Of all the lowlevel radioactive waste disposal compacts, the Central compact, negotiated in 1983, is the only one that reserved responsibility for selecting a location for the regional disposal facility to the compact commission itself, rather than one of the member States. To execute this responsibility, the compact commission entered into a contract with a private sector company to site, develop, and operate the facility in accordance with regulatory site requirements. The compact commission arranged for funding for the project by imposing an assessment on waste generators in the region. In California, government agencies were even more removed from the decision on where to locate the proposed facility, in that complete funding for the project was provided by investment capital from the private sector.

Given the trend toward privatization of governmental services prominent during the 1980 s, it is unclear why most States decided to use governmental entities to propose site locations for the new facilities, instead of delegating the responsibility to the private sector via contract. Governmental agencies responsible for licensing the proposed facilities were already in a position to impose site requirements and other conditions, regardless of who proposed the site. Moreover, most of the State agencies involved in site selection activities planned to employ private companies ultimately to construct and operate the facilities.

\subsubsection{Prevalence of Top-Down Screening Processes}

Top-down mapping strategies have been, by and large, the method of choice among States involved in siting new low-level radioactive waste disposal facilities. However, among the States examined in this report, only in Connecticut was a top-down screening method for site selection prescribed as a matter of law or regulation. (Illinois' new law requires a top-down screening process.) California law required a State agency to "complete a study which identifies those regions of the State within which it is likely the criteria ... could be met." Texas law required the siting agency to study which "areas of the State are relatively more suitable than others for lowlevel waste disposal activities." The decisions to select candidate sites through phased, top-down geotechnical screening methods, therefore, have been mainly administrative, often first appearing in the request for proposals for technical contractors, or in the contract terms between the siting organization and its contractors.

Illinois was the only State that did not begin its site selection process with a statewide exclusionary screening exercise. The State began at the county level, screening only those counties that did not object to being considered. The process conducted in Nebraska began with a nominal statewide screening step, but one of the formal "criteria" at the statewide level was an expression of county interest in being included. Therefore, the maps that resulted from the statewide exclusionary-level screening in Nebraska showed candidate areas that closely coincided with the borders of interested counties. 
Top-down screenings were selected by States for a number of reasons. Screening processes are widely perceived to be an orderly method for site selection that can be done according to a planned schedule. The computerized GIS typically used to implement top-down screenings appears to be objective and free from political bias, important factors if the proposed facility is presented as a locally unwanted land use. On the other hand, screening tens of thousands of square miles down to several hundred acres can stretch the limits of data available for use in such systems. Because of this, the screening exercises implemented by the States inevitably required the application of administrative decisions at strategic points in the processes in order to effectively winnow down the size of the study area.

States have differed in the way they have used automated GIS mapping systems, with some using the maps generated by such systems as final results and some using the output as information for human decisionmakers to consider. Most of the State programs have used GIS systems for both purposes at different stages of their siting processes. The most extreme example of State reliance upon GIS output to pinpoint exact site locations was in Connecticut, where siting officials wanted to avoid the perception that siting decisions were based on inappropriate considerations. The State of Maine, at the other extreme, declared at the outset that map output generated by the GIS system would be used only as one tool for siting officials to consider in reducing the size of the study area to a small number of candidate sites.

\subsubsection{Quantitative and Qualitative Approaches}

Where applicable data are available, applying exclusionary criteria in a screening process is relatively straightforward. Land is eliminated where the available data infer that the condition is present. Applying preference criteria is more complex because the quality of an area or a site depends on consideration of all the preference criteria as a whole. For example, a good site may rank highly with respect to many of preference criteria, but may be deficient with respect to a few.

In applying preference criteria, States have had to choose between two different siting models, a quantitative one or a qualitative one. Quantitative approaches generally involve scoring-weighting techniques. A candidate site (or grid cell or area) is given a numerical score for a preference criterion based on a technical measurement or based on professional judgement. Because all criteria are not of equal importance to siting, a numerical value is assigned to each criterion. The overall score for a candidate site is the summation of its score-times-weight for all of the preference criteria. When used as a method to compare sites or areas, such techniques have the advantage of appearing objective. Because the result is based on a simple mathematical formula, it can be shown that inappropriate considerations did not enter into the decision. Different States applied scoring-weighting techniques at different points in the screening processes. New York applied the technique to compare each of the 1-mi ${ }^{2}$ and 40 -acre grid cells that remained after the exclusionary screening in the candidate area and potential site identification steps, respectively. Only those grid cells with aggregate scores over a specified threshold remained under consideration for the next level of screening. Maine used the results of a similar scoring-weighting exercise to reduce the number of specific sites under consideration from 29 to 10. Texas used the results of a similar technique as information to help siting officials reduce the number of candidate sites from 57 to 26 . In Nebraska, a numerical weighting-scoring system was used to help compare regions of the State. 
Qualitative approaches rely more upon techniques for information exchange and consensus building among experts and specialists. The advantage of such a technique is that it allows for cross fertilization of ideas and values among the participants. Typically, the preference criteria are considered one at a time in a workshop setting. In turn, each candidate site (or grid cell, or area) is discussed with respect to the criterion. A project leader moderates and attempts to bring the discussion to closure. The ranking of each site with respect to each criterion is generally expressed verbally using simple terms, such as high, medium, or low. After evaluation at this level, the outcome for each site is reviewed. Sites are compared on the basis of the verbal rankings for each of the criteria, and on the intuitive assessment of the participants of the importance of each of the criteria. In the same manner as before, the group leader attempts to arrive at a consensus among the group as to which sites are relatively better than others. Processes of this type can be formal and structured, using checklists and other tools, or they can be fairly informal and unstructured.

All of the States that conducted site screenings, at various points in the screening processes, used qualitative approaches to reduce the amount of land area under consideration. For example, in California, two separate phases were conducted to reduce the number of hydrologically closed basins from 71 to 18 . In the first, the siting team considered technical criteria; in the second, institutional factors were considered. Even in Connecticut, which used qualitative techniques the least of all the States, the final selection of three candidate sites was accomplished through a structured workshop emphasizing dialog and interchange between the siting organization and its technical specialists.

\subsubsection{Delineating Screening Units}

The dimensions, or "footprint," for each of the proposed disposal sites and its buffer areas can be approximated. Yet States are not conveniently divided into units of several hundred acres to facilitate site screening exercises. In order to compare one region or area against another, the borders of the region or area must be outlined.

North Carolina, New York, and Michigan began statewide screenings by overlaying a map of the State with an array of grid cells, $1 \mathrm{mi}^{2}$ or $1 \mathrm{~km}^{2}$. After excluding grid cells in which an undesirable feature is present, the pattern formed by nonexcluded grids cell provided the basis for delineating area boundaries for further study. In North Carolina, for example, areas were bounded by beginning with grid cells or clusters of grids cells that met certain favorable conditions. Specific area boundaries were hand-drawn to include portions of abutting grid cells that also met these conditions. Connecticut and Maine began State-level screenings using more analog methods that employed computer systems to mechanically plot the borders of excluded zones around undesirable features. Using these methods, small features represented by dots and larger features depicted by polygonal shapes were used as the seed locations for the excluded zones. In California and Texas, a broad-brush exclusionary screening was done by manual methods instead of computer-based systems. In California, specific boundaries to delineate competing areas were derived from maps showing the locations of hydrologically closed basins in the desert.

In Illinois, the siting agency began with county units. At that scale, maps were plotted by a GIS system showing areas within the counties that were "potentially suitable," "difficult to license," 
or "excluded." The siting process in Nebraska, also began essentially at the county level. In screening counties in Nebraska, information was transposed manually onto a composite map for each county from base maps. Texas, also, used counties as the beginning units in screening the State for State-owned land. In New York, the siting organization used town borders to delineate candidate areas, taking advantage of the subdivision of the State into geopolitical townships. Towns in which a large portion of 1-mi grid cells appeared favorable were included as candidate areas. Contiguous towns with favorable conditions were considered a single area.

The purpose of delineating regional or area boundaries in which to focus a more detailed search for alternative sites is partially one of practicality, since even "excluded" areas may contain small parcels of land that meet site requirements. In Michigan, having exhausted all data available for application at the State level screening, the siting authority was still left with 79 noncontiguous areas potentially suitable for the disposal site. Due in part to the ambitious schedule that was driven by the Federal law, the siting authority decided to select the three largest of these areas for screening at the smaller scale. All the other areas were "deferred" from consideration, meaning they would only be considered if a suitable site in one of the three larger areas could not be found.

Connecticut's site screening process differed markedly from all of the others with respect to deletion of screening units. Throughout the process, all of the screening overlay steps were done uniformly across the small State, instead of targeting successively smaller areas for more detailed evaluation (e.g., towns in New York, closed basins in California, geophysical regions in Texas, "potentially suitable areas" in the other States). As a result, the intermediate map results for Connecticut did not yield the common "holstein" pattern showing large splotches of land screened in or out. Instead, the maps presented a "measles" pattern of hundreds of tiny dots spread relatively evenly over the entire State. While arguably more equitable, the results required siting officials to find inventive ways to eliminate all but a handful of the dots.

\subsubsection{Excluding Land Area from Further Consideration}

The exclusion of land area during a screening process naturally implies that the land is technically unsuitable for the disposal facility. In truth, however, all but a few hundred acres of land representing a small number of specific candidate sites eventually are "excluded" at some point in the process. Obviously, the one, two, or three sites eventually selected through the process are not the only locations in the State that might be suitable for the disposal facility.

Some States have been careful to avoid the suggestion that any land is actually being "excluded," once and for all, from further consideration. In these States, land screened out during the process has been considered by the siting officials to be "deferred" from consideration. In Michigan, once it was determined that suitable sites could not be located in the three finalist areas, the siting agency doubled back and examined some 79 areas that had been deferred. In Nebraska, one of the eventual finalist sites was restored for consideration after locally available information indicated that the general statewide data used in screening were in error. The WakeChatham site in North Carolina, which had earlier been deferred, was reconsidered after a legislative committee recommended that the siting agency give preference to land near nuclear power plants. 
Because of the implication that excluded or deferred land is unsuitable, it has also been difficult to conduct such screenings concurrently with volunteer solicitation programs. Unless, by bizarre coincidence, the volunteered parcel happens to be one of the final candidate sites identified through the screening process, its inclusion in the pool of final candidate sites may appear inappropriate or expedient. Although most of the State processes have included modest efforts to solicit volunteered sites in supportive communities, States have had difficulty integrating volunteer efforts into site screening processes.

\subsubsection{Conclusions}

The disparity between the public's perception of site selection processes as an exacting science and the realities involved in their practical application has been a root cause of controversy in most of the States that have used these methods. This misunderstanding has spawned lawsuits, investigations, and legislative intervention in most of the States.

In using top-down screening methods, siting officials have been faced with a Faustian choice. The appearance of objectivity gained in relying on the output from computerized GIS systems inevitably is offset by shortcomings related to the use of data that are, by their nature, imperfect. In a sense, all data available in such systems are surrogate data, either because they rely upon a limited number of data points to generalize about a much larger area (e.g., depth to groundwater measurements), or because of the large potential for errors in the data (e.g., an outdated map showing well locations). In different States, site opponents have criticized the siting processes on both counts. In New York and North Carolina, critics contended that the siting decisions were based on political considerations, in spite of the use of GIS as a tool in siting. In Connecticut, opponents did not allege that the decisions were biased, but instead charged that the data used in the site screening and decisions made in executing the screening were flawed.

Where alternatives to top-down approaches have been used to site disposal facilities for lowlevel radioactive waste (e.g., volunteer programs emphasizing benefits and incentive programs), opponents of the efforts have charged that siting officials were attempting to "bribe" the communities into accepting the facilities. The Illinois Siting Commission, for example, criticized the siting organization's efforts to promote the idea of hosting the facility to the local community. Yet, current academic literature on the art of siting controversial facilities leans heavily in favor of such voluntary methods.

The experiences of States and compacts regions over the past 10 years in attempting to site new facilities for disposal of low-level radioactive waste suggest that:

- A limited number of critical site suitability requirements should be identified, defined, and documented, but local preferences and values related to all aspects of land use policy should not be preempted at the State level

- Statutory requirements for site suitability, if any, should be limited to special considerations such as policies on local acceptance and the use of publicly owned land 
- Beyond State regulations that apply the Federal site suitability requirements, regulations should avoid preempting technical decisions on specific quantitative tests and data sets to be used

- Computerized GIS systems can be a tool in alerting siting officials to potential conditions that might exclude a candidate site from consideration

- Where there is a technical consensus that data in a GIS system are reliable and faithfully represent a site suitability requirement, the production of maps showing excluded areas may be a useful and cost-effective means in helping to focus subsequent site selection efforts

- In virtually all cases, existing applicable data alone are not sufficient to allow for complete top to bottom GIS screening of a State to identify candidate sites

- Planning for a top to bottom site screening process should include the strategy for delineating screening units, and contingency plans for reducing the amount of land under consideration in the event that the strategy fails to eliminate a sufficient amount of area

- Before adopting top-down screening as the primary method for selecting candidate sites, States should examine current literature to identify and evaluate alternative approaches for siting unpopular facilities

- Before assigning government entities the responsibility for siting and developing the disposal facility, States should evaluate the option of delegating the responsibility through contract to companies in the private sector, as was done in California and the Central compact region (in Nebraska). 


\section{REFERENCES}

California Department of Health Services, Low-Level Radioactive Waste Area Suitability Study, not dated.

League of Women Voters Southern California Regional Task Force (Gloria Anderson), Disposing of Low-Level Radioactive Waste in California: A Guidebook for Citizen Participation, June 1990.

US Ecology, Inc., California Low-Level Radioactive Waste Disposal Facility Candidate Sites Selection Report, June 1987.

Low-Level Radioactive Waste Disposal Facility Site Screening Report, draft, Revision 1, Battelle Memorial Institute for the Connecticut Hazardous Waste Management Service, October 1991.

Low-Level Radioactive Waste Disposal Facility Site Screening Process Review, TRC Environmental Corporation for the Connecticut Hazardous Waste Management Service, January 1993.

Report on Independent Quality Review of 1991 Statewide Screening, memorandum from Ronald Gingerich, Director, Low-Level Radioactive Waste Program, Connecticut Hazardous Waste Management Service, to Board of Directors, February 3, 1993.

Illinois Department of Nuclear Safety, Milestones in Low-Level Radioactive Waste Management, not dated.

Illinois Department of Nuclear Safety, Site Identification Plan and Status Report, January 1988.

Illinois Low-Level Radioactive Waste Siting Commission, Martinsville: Report of the Illinois LowLevel Radioactive Waste Disposal Facility Siting Commission on its Inquiry into the Martinsville Alternative Site, not dated.

Technical Advisory Committee to the Illinois Department of Nuclear Safety, Review and Evaluation of the Selection Process for the Low-Level Radioactive Waste Disposal Facility, Revised Final Report, March 1990.

Low-Level Radioactive Waste Disposal Facility Siting Methodology; Exclusion Criteria, Fundamental Performance and Avoidance Screening Factors, prepared for the Maine Low-Level Radioactive Waste Authority by the E.C. Jordan Co., Stone \& Webster Engineering Corp. and James W. Sewall Co., July 1990.

"An Evaluation of the Michigan Siting Criteria and Their Effect on the Elimination of Land Area for Siting a Low-Level Radioactive Waste Isolation Facility," prepared by Battelle Memorial Institute for the Michigan Low-Level Radioactive Waste Authority, November 1993. 
Michigan State University (Schultink, et al.), Design and Implementation of a Statewide Screening Method to Determine Comparative Area Suitabilities for Near-Surface Isolation of Low-Level Radioactive Waste, Part A: Implementation of Exclusionary Variables to Identify Potentially Suitable Areas for Radioactive Waste Isolation in Michigan, September 1989.

US Ecology, Inc., Site Identification Process for the Central Interstate Compact Low-Level Radioactive Waste Disposal Facility, final report, June 1989.

New York State Low-Level Radioactive Waste Siting Commission, Statewide Exclusionary Screening Report, September 1988.

New York State Low-Level Radioactive Waste Siting Commission, Candidate Area Identification Report, December 1988.

New York State Low-Level Radioactive Waste Siting Commission, Report on Potential Sites Identification, September 1989.

New York State Low-Level Radioactive Waste Siting Commission, Site Selection Presentation, Parts 1-4, various dates July 17, 1991, through November 14, 1991.

Ebasco Services, Inc., Phase 1 Screening Study; Identification of Potentially Suitable Areas, November 30, 1988.

Ebasco Services, Inc., Review of Chem-Nuclear Systems, Inc., Precharacterization Data, Reports and Recommendations to Characterize Favorable Site Areas, not dated.

Staff of the North Carolina Low-Level Radioactive Waste Management Authority and ChemNuclear Systems, Inc., Response to Chatham and Richmond County Reports on the Site Selection Process for the North Carolina Low-Level Radioactive Waste Disposal Facility, October 1, 1993.

Texas Low-Level Radioactive Waste Disposal Authority, Siting of a Low-Level Radioactive Waste Disposal Facility in Texas; Volume 1, March 1985.

Texas Low-Level Radioactive Waste Disposal Authority, Siting of a Low-Level Radioactive Waste Disposal Facility in Texas; Volume 3: Evaluation of State-Owned Lands, October 1985. 